\title{
A Survey of Selected Classical Chinese Art Songs for Solo Voice and Piano from 1920 to 1950
}

\author{
Tingting Chang \\ West Virginia University College of Creative Arts School of Music, tchang5@mix.wvu.edu
}

Follow this and additional works at: https://researchrepository.wvu.edu/etd

Part of the Music Performance Commons

\section{Recommended Citation}

Chang, Tingting, "A Survey of Selected Classical Chinese Art Songs for Solo Voice and Piano from 1920 to 1950" (2020). Graduate Theses, Dissertations, and Problem Reports. 7518.

https://researchrepository.wvu.edu/etd/7518

This Dissertation is protected by copyright and/or related rights. It has been brought to you by the The Research Repository @ WVU with permission from the rights-holder(s). You are free to use this Dissertation in any way that is permitted by the copyright and related rights legislation that applies to your use. For other uses you must obtain permission from the rights-holder(s) directly, unless additional rights are indicated by a Creative Commons license in the record and/ or on the work itself. This Dissertation has been accepted for inclusion in WVU Graduate Theses, Dissertations, and Problem Reports collection by an authorized administrator of The Research Repository @ WVU.

For more information, please contact researchrepository@mail.wvu.edu. 

and Piano from 1920 to 1950

Tingting Chang

Follow this and additional works at: https://researchrepository.wvu.edu/etd

Part of the Music Performance Commons 


\title{
A Survey of Selected Classical Chinese Art Songs for Solo Voice and Piano from 1920 to 1950
}

\author{
Tingting Chang
}
A Doctoral Research Project submitted to College of Creative Arts at
West Virginia University

in partial fulfillment of the requirements for the degree of

Doctor of Musical Arts

in

Voice Performance

Hope Koehler, D.M.A., Committee Chair, Research advisor

William Koehler, D.M.A.

William Haller, D.M.A.

Peter Amstutz, D.M.A.

Richard Dull, Ph. D.

School of Music

Morgantown, West Virginia

2020

Keywords: Chinese Art Songs 1920 to 1950, Chinese Repertoire, Voice and Piano, Chinese Songs for Students, Chinese Art Songs and Poems

Copyright 2020 Tingting Chang 


\begin{abstract}
A Survey of Selected Classical Chinese Art Songs for Solo Voice and Piano from 1920 to 1950

Tingting Chang
\end{abstract}

This study aims to provide a repertoire guide of Chinese art songs for the pedagogical and research needs of musicians and scholars. Chinese art songs are derived from Western art songs. This work provides a valuable resource outside the scope of the standard art song repertoire. There are very limited studies with annotated lists of Chinese art song repertoire in English. Therefore, it is difficult for teachers to search for specific Chinese art songs to utilize with students who have different voice types and learning levels. This study will provide a practical tool that will meet these pedagogical needs.

All the Chinese art songs selected for use in this study were composed between 1920 and 1950. Most of these songs were original works; some were arranged with piano accompaniment at a later point. Most of the works included in this study were originally composed for solo voice and piano. Several chamber pieces are also included, but there are no songs included that have orchestral accompaniments. With each entry there is an annotation providing information about the song. This information typically includes the work's composer, title, publisher/year, poet, poem style, voice type (gender/classifications), tessitura, difficulty level (beginning/intermediate/advanced), duration, and brief comments.

Learning Chinese art songs is beneficial for singers, teachers, and music scholars. This study provides a new resource which aims to make this invaluable vocal repertoire more accessible to teachers and musicians. The unique tunes and musical styles of Chinese art songs also bring fresh varieties of sound for audiences. Moreover, Chinese art songs are mostly based on both Classical Chinese poetry and modern Chinese poetry written by renowned Chinese poets. The Chinese art songs analyzed in this study also reflect important historical and cultural revolutions in China. This study provides a channel for western scholars and musicologists to study Chinese art and culture through music and poems, making a new field for scholarly exploration more readily available. 
To my husband Jing Zhang, and my child Annie Zhang 


\section{ACKNOWLEDGEMENTS}

I would like to show my deep gratitude to my committee chair and advisor Dr. Hope Koehler. Dr. Koehler is patient and wise. She inspired me with her knowledge of art and guided me throughout my learning journey at WVU.

I would also like to express my deep gratitude to my committee members, Dr. William Koehler, Dr. William Haller, Dr. Peter Amstutz, and Dr. Richard Dull. I am grateful for their continuous support and advice. It would not be possible for me to accomplish the degree without their help.

Finally, I would like to express my special thanks to my husband Jing Zhang, and my little girl Annie for your love and support! Your smiles are my motivation! 


\section{TABLE OF CONTENT}

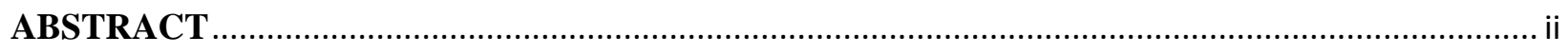

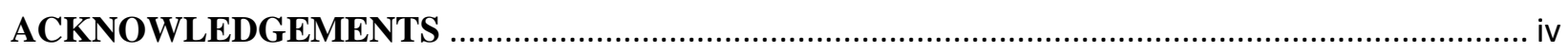

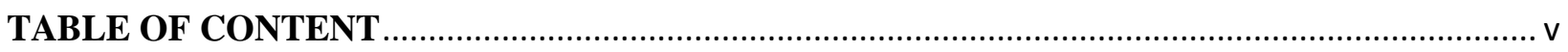

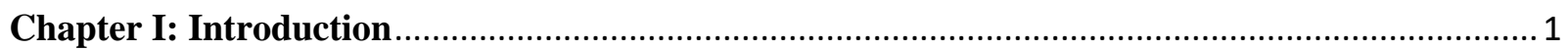

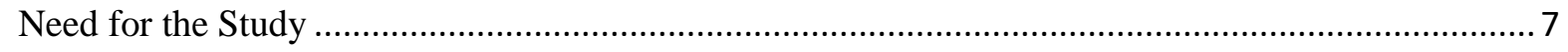

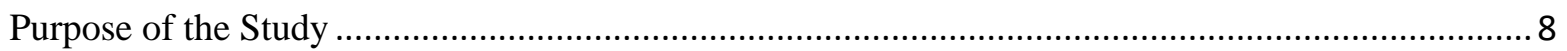

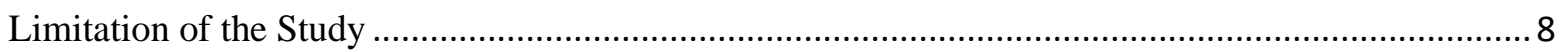

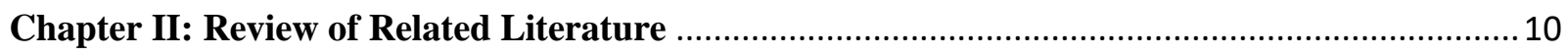

Chapter III: Annotated Listing of Chinese Art Songs in the 1920s......................................16

Chapter IV: Annotated Listing of Chinese Art Songs in the 1930s ........................................27

Chapter V: Annotated Listing of Chinese Art Songs in the 1940s ........................................67

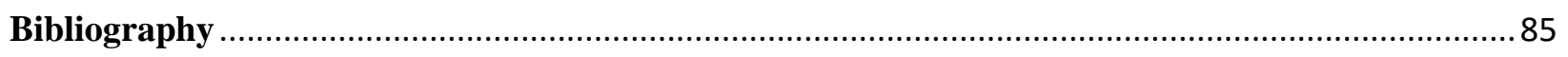

Appendix I: Lyrics and Translations for Chinese Art Songs from the 1920s ............................... 88

Appendix II : Lyrics and Translations for Chinese Art Songs from the 1930s .............................. 100

Appendix III: Lyrics and Translations for Chinese Art Songs from the 1940s ............................. 140

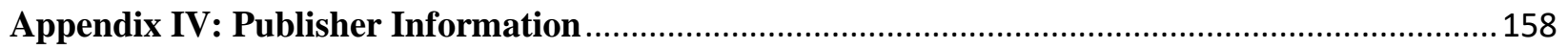

Appendix V: Composer Index in Alphabetic Order ................................................................... 1

Appendix VI: Title Index in Alphabetic Order ........................................................................... 4 


\section{Chapter I: Introduction}

Chinese art song first appeared at the beginning of the 20th century. Before then, Chinese voice performance was dominated by Chinese Opera, folk songs and traditional songs. The emergence of the Chinese art song was closely related to its historical background, during a time when radical changes were happening in social, political, and cultural environments in China. The most influential change was the New Culture movement (also called the May Fourth movement). It was an ideological and cultural innovation that was led by the intellectuals and scholars who were seeking solutions to the social and political crisis in China. They opposed the traditional social system and literary foundation and advocated for the idea of democratic freedom from the West, hoping to use western science and education to change Chinese society. Thus, they initiated vernacular literature and civilian education as a beginning of the change. ${ }^{1}$ As a result, the modern Chinese poetry emerged. Pioneer poets like Hu Shi and Cai Yuanpei strongly advocated for the modern Chinese poetry. It was created in distinct contrast with classical Chinese poetry. The modern Chinese poems were written in vernacular language instead of classical Chinese. Classical Chinese was the traditional written language that was only used by the upper-class and royals. All Classical Chinese poetry exclusively used classical Chinese that common people could not understand. Thus, using vernacular language was an innovative breakthrough for the New Culture movement. From then on, poems and literacy could be appreciated by common people, expanding the scope of civilian culture. And more important, it prepared the literacy foundation for the birth of the Chinese art song. ${ }^{2}$

\footnotetext{
${ }^{1}$ Yuhe Wang, "Dreams of May 4th: Written in Commemoration of the 90th Anniversary of the May Fourth Movement" [in Chinese], Huangzhong/Journal of Wehan Conservatory of Music 90, no. 2 (Summer 2009): 7. 2 Min Dai, "Musical Thinking of the Common People During the May Fourth Period" [in Chinese], Journal of Xinghai Conservatory of Music 118, no.1 (March 2010): 57-58.
} 
In the first half of the $20^{\text {th }}$ century, the development of the Chinese art song can be divided into two periods: the first period (1920-1930) and the second period (1930-1950). The first period was the beginning of Chinese art song. It was a time when many Chinese musicians traveled abroad to learn the western music system in Europe and the U.S. They considered the western music system to be the way to improve Chinese music. They creatively combined the composition technique of western music with Chinese literacy and ethnic music style. The Chinese art song, as a new genre, was born in this fusion of innovations. ${ }^{3}$ The pioneer musicians of Chinese art songs were Xiao Youmei (1884-1940), Qing Zhu (1893-1959), ${ }^{4}$ and Zhao Yuanren (1892-1982). The first Chinese art song was "Da Jiang Dong Qu" (The River Flowing to the East, 1920) composed by Qing Zhu. Later, Xiao Youmei published his first song book Jin Yue Chu Ji (Music Today First Collection) in 1922. It included classic art songs "Wen" (Question, 1922) and "Nan Fei Zhi Yan Yu" (The Tale of the Geese Flying South, 1923). ${ }^{5}$ The most influential composer among them was Zhao Yuanren (1892-1982). He was the first person who established the ethnic development of Chinese art songs. He composed more than 100 songs in his lifetime. His first songbook Xin Shi Ge Ji (New Songs Collection) was published in $1928 .{ }^{6}$

Chinese art songs were different from other types of songs, such as folk songs and Quyi (also called ballad singing) in China. It inherited essential characteristics from western art songs, especially German lied in the 19th century. First, Chinese composers established a high standard for selecting poems for their music. The music composition was primarily to express poetic

\footnotetext{
${ }^{3}$ Xiaoyan Xia, "The History of Chinese Art Songs in the First Half of the 20th Century" [in Chinese], Sounds of the Nature/ Journal of Tianjin Conservatory of Music 78, no. 3 (January 2004): 85.

${ }^{4}$ Qing Zhu's real name was Liao Shang Guo.

${ }^{5}$ Yan Li, "Development of Modern Art Songs in China" [in Chinese], Zhon Guo Yin Yue/Chinese Music 3, no. 1 (January 1990): 36-37.

${ }^{6}$ Yuhe Wang, The History of Modern Chinese Music [in Chinese], (Beijing: People's Music Publishing House, 2009), 84.
} 
temperament and literary aesthetics. As Lu Zaiyi (1943-), a contemporary composer, stated: "it is the expressing of personal feelings...... lyrics are poems with strong musicality and literariness. Some lyrics were directly chosen from famous poems."7 Secondly, themes of art songs included self-expression, freedom, individual feelings, humanity and real-life situations. For example, “Jiao Wo Ru He Bu Xiang Ta” (How Can I Keep from Thinking of You?, 1926) by Zhao Yuanren was about the longing for a lover who is far away. Moreover, the accompaniment was no longer a supplement to the voice, but an integral part of the music. More functions included setting the atmosphere, expressing the theme, and uniting all sections of a song. ${ }^{8}$

While early Chinese art songs imitated western art songs in many aspects, it was deeply rooted in Chinese culture and developed its own unique ethnic style. ${ }^{9}$ The pioneer composers established the foundation for this ethnic style at the beginning of the 20th century. The first composer doing this was Zhao Yuanren. He pointed out the importance of western harmony in transforming Chinese music, stating "compared with western music, Chinese music has the disadvantage in harmony. If we have the foundation of harmony, our music can have more farreaching development." ${ }^{" 10}$ He was also a linguistics expert who had studied many ethnic dialects and conversations from all over China. He used slides and ornaments and even tunes of children's singing to mimic the accents of different regions. He called it "adding Chinese flavor" to the music. ${ }^{11}$ For example, the melody of "Ting Yu" (Listening to the Rain, 1928) imitated

\footnotetext{
${ }^{7}$ Zaiyi Lu, "My Opinions on the Composing of Chinese Art Song" [in Chinese], Ren Min Yin Yue/ People's Music 515, no. 8 (August 2007): 8.

${ }^{8}$ YueMei Sun and Chang Liu, The Appreciation of Chinese Art Songs [in Chinese], (Hefei: An Hui Art Publishing House,2015), 12.

${ }^{9}$ Lingling Yang, "The Compositional Pattern and Aesthetic Format of Chinese Art Songs" [in Chinese], Journal of Xi'an Conservatory of Music 142, no. 4 (December 2013):126-127.

10 Jinshou Zeng, "Review of the Origin and Development of Art Songs in China (1920-1949)" [in Chinese], pts1, Journal of Xi'an Conservatory of Music 60, no. 2 (Summer 1993): 71-72.

${ }^{11}$ Shaotong Zhang, "The Chinese Art Song and Chinese Culture" [in Chinese], People's Music 521, no. 11 (November 2007): 24-25.
} 
people's chanting tunes of classical Chinese poems in the city of Changzhou, a southern city where people's dialect had about three thousand years of history. ${ }^{12}$ In addition, Zhao used modern Chinese poetry as lyrics. It was a style of free verse poetry that does not follow the prescribed pattern of classical Chinese poetry. To fit the form of the selected poem, he rarely used strophic form in his songs.

In the second period (1930-1950), according to the selected poetry style, Chinese art songs can be divided into two types: art songs based on classical Chinese poetry and art songs based on modern Chinese poetry. ${ }^{13}$ For art songs based on classical Chinese poetry, the primary purpose was to express the aesthetic of the poems. Classical Chinese poetry has a long history dating back to the Zhou Dynasty (1106 BC-249BC) when the first poetry book Shijing (The Classic of Odes) (11th century BC) was written. Its development continued to the Qing Dynasty (1636-1912) a span of about 2000 years. ${ }^{14}$ The long developing history produced various poems with different styles and patterns. It was a challenging task to compose songs in this style because it required the composers to have substantial knowledge of classical Chinese literature. Qing Zhu (1893-1959) was the first composer who introduced Classical Chinese poetry into this genre. As one of his representative works, "Da Jiang Dong Qu" (1920) set the poem "Reflections on the Ancient Red Cliff--To the Tune of Nian Nu Iiao". The poem is a lyric $(\mathrm{Ci})$ poem ${ }^{15}$ by the famous poet Su Shi (1037-1101) of the Song Dynasty (960-1279). ${ }^{16}$ Huang Zi (1904-1938) was

\footnotetext{
12 RenKang Qian, “Analysis of Songs Composed by Zhao Yuanren” [in Chinese], Musicology in China no. 1, (January 1988): 7-8.

${ }^{13}$ Yuhe Wang, "New Music of China: Its Development under the Blending of Chinese and Western Cultures through the First Half of the 20th Century" [in Chinese], pts2, Journal of the Central Conservatory of Music 60, no. 3, (January 1995):77-78.

${ }^{14}$ MeiFeng Kang Chi, “A Performance Guide for Contemporary Chinese Art Songs from Taiwan” (Ed.D. diss., Teachers College, Columbia University,1996).

${ }^{15} \mathrm{Ci}$ is a type of Classical Chinese poetry in China. It can also be called lyric poetry or Song Ci.

${ }^{16}$ YueMei Sun and Chang Liu, The Appreciation of Chinese Art Songs [in Chinese], (Hefei: An Hui Art Publishing House,2015), 21.
} 
another leading composer for this type of art song. He used many Classical Chinese poems from different historical periods. For example, the poem of "Nan Xiang Zi" (Song of the Southern Country, 1933), is a lyric (Ci) poem written by poet Xin QiJi (1104-1207) from the Song Dynasty (960-1279). "Hua Fei Hua" (Flowers are Not Flowers) is a Shi poem ${ }^{17}$ written by poet Bai Juyi (772-846) from the Tang Dynasty (618-907ce). ${ }^{18}$ Huang Zi and Qing Zhu inspired many other composers, like Zhang Xiaohu (1914-1997), Ma Sicong (1912-1987), Liu Xuean (1905-1985) and Tan Xiaolin (1912-1948).

Unlike art songs based on classical Chinese poetry, art songs based on modern Chinese poetry used vernacular language. It was easier for the common people to understand and appreciate. The primary purpose was not to express the aesthetics but to express personal feelings and realities. There was a wider range of emotions presented within a single song. Some composers utilized recitative-like composition from western opera to reflect the Chinese speaking tones and changing emotions. For example, He Luting (1903-1999) used recitative-like melody in his song "Jialing Jiang Shang" (On the Jialing River, 1939) to narrate people's stories from the war. ${ }^{19}$ This storytelling method made the expression more realistic and easier to understand. Other composers like Huangzi, Liu Xue'an, Chen Tianhe (1911-1955), and Jiang Dingxian (1912-2000), also composed many art songs that were based on modern Chinese poetry.

During this period, the Sino-Japanese war and the political movement gave rise to another new style: patriotic art songs. In 1931, Japan invaded the northeast region of China

\footnotetext{
17 Shi poetry is another type of Classical Chinese poetry, in contrast with Ci poetry (lyric poetry).

18 Jinshou Zeng, "Review of the Origin and Development of Art Song in China (1920-1949)" [in Chinese], pts1, Journal of Xi'an Conservatory of Music 60, no. 2 (Summer 1993): 71-72.

${ }^{19}$ Xiaoyan Xia, "The History of Chinese Art Songs in the First Half of the 20th Century" [in Chinese], Sounds of nature/ Journal of Tianjin Conservatory of Music 78, no. 3 (January 2004): 89.
} 
causing the 2nd Sino-Japanese war, which was part of WWII. ${ }^{20}$ Many intellectuals started the Anti-Japanese movement. Patriotic songs became an important part of the movement. The lyrics were usually very expressive, easy to understand, and war-related. Some described people's desperation and some expressed the hope for victory and called people to fight. Nie Er composed China's national anthem "Yi Yong Jun Jin Xing Qu" (March of the Volunteer) in 1935. The anthem was a typical patriotic song for calling people to fight for freedom. He also wrote many songs that depict people's war suffering, like "Meiniang Qu" (Song of Meiniang, 1935). This song described a woman's despair when she learned that her lover was wounded and lost his memory during the war. Another important composer was Xian Xinghai (1905-1945), who wrote his best-known patriotic piece Yellow River Cantata in 1938, describing the stories of ordinary people during the war. It was a large-scale vocal work that consists of solo, duet, chorus, and monologue speaking. Three solo songs from the "Yellow River Cantata," "Huanghe Song" (Ode to Yellow River), "Huang Shui Yao" (Ballad of Yellow Water) and "Huanghe Yuan" (The Yellow River Resentment), became classics in the Chinese art song repertoire.

In 1949, the new government proclaimed the establishment of the People Republic of China (1949-present), marking the ending of WWII and the Chinese Civil War. The relatively stable and peaceful political environment provided favorable conditions for the development of Chinese art songs. Composers gave more attention to folk songs and considered them a new source of developing the ethnic style of Chinese art songs. Some composers collected folk songs of different regions into songbooks and arranged them into art song style. Ding ShanDe (19111995) was a representative composer for this style of art songs. His song "Huaihua Ji Shi Kai" (When will Sephora Bloom, 1951) was an art song that he arranged from a folk song in the

\footnotetext{
${ }^{20}$ Xiaonong Zhang, History of Chinese Vocal Music [in Chinese], (Shanghai: Shanghai Music Publishing House, 2015), 157-159.
} 
Sichuan province in China. It was originally a mountain song that was sung during special events in Sichuan's countryside. The arrangement gave the piano a very important role as demonstrated in the long prelude and its conversation with the voice counterpart. ${ }^{21}$ In another aspect, some composers boldly introduced modern western composition techniques into Chinese art songs. As early as the 1940s, Tan Xiao Lin (1912-1948) composed "Zhengqi Ge" (Positive Song, 1947). Tan used his teacher Paul Smith's music system with a classical Chinese poem written by the famous poet Wen TianXiang (1236-1283) in the Song Dynasty. ${ }^{22}$ In 1980, Luo Zhongrong (1924-) used the twelve-tone technique in his art song "She Jiang Cai Furong" (Crossing the River to Pick Hibiscus). It was based on Yuefu which is another type of classical Chinese poetry, Yuefu is an ancient poetry specifically composed for singing in the Han Dynasty (206 BC-220 AD). He combined twelve tone and Chinese pentatonic scale with classical Chinese language, creatively expressed in an artistic conception. ${ }^{23}$ After 1950, the ethnic style of Chinese music became more mature with a new generation of musicians magnifying the influence of Chinese art songs. With the establishment of formal music academies and the advances of music performances, Chinese art songs were increasingly accepted and appreciated by more audiences.

\section{Need for the Study}

Chinese art song, as a unique modern vocal music genre, has been derived from western music and deeply rooted in Chinese culture. Over the decades, it has developed its own ethnic style. Art song composers chose poems of high musical and literary quality, demonstrating the essence of Chinese culture in both traditional and modern literature, while telling stories of

\footnotetext{
${ }^{21}$ Qianghua Xue, "On the Development of Chinese Art Song” [in Chinese], Music \& performance/ Journal of Nanjing Arts Institute 99, no. 1 (January 2004):87-89.

${ }^{22}$ Xiaoyan Xia, "The History of Chinese Art Songs in the First Half of the 20th Century" [in Chinese], Sounds of nature/ Journal of Tianjin Conservatory of Music 78, no. 3 (January 2004): 90.

${ }^{23}$ YueMei Sun and Chang Liu, The Appreciation of Chinese Art Songs [in Chinese], (Hefei: An Hui Art Publishing House,2015), 11.
} 
normal people. It provided a channel for western scholars and musicians to study Chinese art and culture through music.

Learning Chinese art songs can be very useful for western musicians and musical scholars. Chinese art songs can be a valuable part of the vocal repertoire for professional singers. The unique tunes and music styles bring new variety for audiences. It can also expand the interest of students, bringing a new field for exploring. However, there are very limited studies with annotated lists on Chinese art song repertoire in English. It is difficult for teachers to search appropriate Chinese art songs for different types of students. It can be especially challenging to find a certain voice type, difficulty level, and song style for young singers. Thus, further study is necessary regarding this topic.

\section{Purpose of the Study}

The purpose of this study is to survey and create a repertoire guide for musicians and scholars, who need to perform, teach, and research Chinese art songs. This study will provide a practical and concise resource for teachers and singers who are looking for new songs outside the scope of the standard art-song repertoire. It will also provide teachers with useful information like different voice types (gender/classifications), and various difficulty levels (beginning, intermate, and advanced) to satisfy their pedagogical needs.

\section{Limitation of the Study}

In this research, all the selected Chinese art songs were composed between 1920 and 1950. While most of them were original works, some were arrangements with piano accompaniment. The name of arrangers will be noted in the entry, if applicable. Most of the works included in the study were originally composed for solo voice and piano. Several chamber pieces will be included, but there will be no songs included that have orchestral accompaniments. 
Music works will be organized in alphabetical order by composer's last name. Each entry generally includes composer, piano arrangement, title, title translation, publisher (in the appendix, the publisher information will be provided), poet, poem style, difficulty level (beginning/intermediate/advanced), duration (how long the pieces are), voice type (gender/classifications), tessitura, voice characteristics, piano accompaniment and brief comments (songs style, music style if applicable). The appendix I, II, and III will provide lyric in Chinese and its English translation. The appendix V and VI will provide tables listing all composers and songs discussed in this study. The tables will also include the Chinese characters, pinyin, and English translation for each entry. 


\section{Chapter II: Review of Related Literature}

There are many studies focusing on Chinese art songs. Their topics include music history, music analysis, composition styles, and performance guide. However, there are very few studies that have surveyed and compiled the repertoire of Chinese art songs in an annotated bibliography. Current research and studies provide insufficient information due to the limited number of songs and lack of information such as difficulty levels and voice types. In addition, many books and articles about art songs are only available in Chinese, remaining inaccessible to most English speaking readers. The related literature to this topic includes books, dissertations, and articles. Databases that have been used for searching include RILM Abstracts of Musical Literature, ProQuest Dissertations and Theses Global, Library of Congress.

Five dissertations were found to be related with this topic. Some are performance guides focusing on style introduction and musical analysis. Some focus on the historical study of the genre. There is also one study that exclusively discussed art songs in Taiwan; however, it includes no song from mainland China. Books relating to the topic of this study are mostly written in Chinese. The three books included here are not available in English. Two of them are performance guides for Chinese art songs in the 20th century. The other one is about music appreciation. In terms of articles, most of the related studies were written for historical review, style introduction, and music analysis. Those articles are only available in Chinese. Two key articles include in the study were written by Zen Jinshou and Xue Qianghua. The two articles briefly describe the development process of Chinese art songs in the 20th century, the definition of Chinese art songs, and their characteristics in each period. 
In 1995, Hallis Xiang wrote the dissertation Chinese Art Song from 1912-1949. ${ }^{24}$ It is a performance guide to eighteen selected songs of Chinese art songs from twelve composers. It briefly introduces the historical background at the beginning of the 20th century. Three chapters discuss different development stages of Chinese art songs. The composers and the art songs appear in chronological order. Xiang analyzes representative songs composed by influential composers of each period. He discusses lyric styles and music characteristics of each song. In the appendices, Xiang provides music scores, pronunciation guides, and word-by-word translations for each song. Xiang also presents additional introductions to Chinese music, including Chinese mode and different styles of Chinese poetry. It is a great introductory study for singers interested in understanding the historical background and characteristics of Chinese vocal music. However, it is not a study for searching Chinese art song repertoire. The number of songs and composers included in the study is limited.

In A Performer's Guide to Selected Chinese Art Songs by Twentieth-century Chinese, Tyan Jaan-Ay provides music analysis of fifteen Chinese songs in the 20th century. Tyan organizes the dissertation into three sections: historical background, phonetic guide, and fifteen songs analysis. The phonetic guide is to help non-Chinese singers. The guide is based on the International Phonetic Alphabet and the Singer's Phonetic Alphabet Guide for Mandarin Chinese. ${ }^{25}$ All Pinyin, Zhuyin, and IPA symbols are listed in the examples with the comparison of English and German words. It also uses charts, diagrams, and illustrations to demonstrate the pronunciation. It is a useful guide for singers who need to learn Chinese diction. However, the

\footnotetext{
${ }^{24}$ Xiang Chen Hallis, "Chinese Art Song from 1912-1949" (D.M.A. diss., The University of Texas at Austin, 1995).

25 Jann-Ay Tyan, "A Performer's Guide to Selected Chinese Art Songs by Twentieth-century Chinese Composers"

(D.A. diss., The Southern Baptist Theological Seminary, 2003).
} 
songs included in the research are also limited. This study was not designed for researching and selecting art songs.

Chi Mei-Fung Kang wrote A Performance Guide for Contemporary Chinese Art Songs from Taiwan in 1996. Chi introduces the history of Chinese poetry of traditional and modern styles. She developed a Mandarin-based Chinese phonetic guide, called Singer's Phonetic Alphabet Guide with the orthographic explanation. She also compared it with the IPA system to make it easier for the singers to learn. The phonetic system of Chinese later became the main source for Tyan Jaan-Ay's phonetic guide in her dissertation. ${ }^{26}$ However, the songs in this study are exclusively focused on composers from the region of Taiwan. The works from Mainland China are not included.

In 20th Century Chinese Solo Songs: A Historical and Analytical Study of Selected Chinese Solo Songs Composed and Arranged by Chinese Composers, ${ }^{27}$ Yang Schuman Chuo discussed the development of Chinese songs from a historical point of view. It includes a catalogue that listed selected Chinese songs with lyric translation, music scores and publishing information. However, it is not a study focused on the Chinese art song. It also includes folk songs, children's songs, and choral works. The songs are not only from composers of mainland China, but also those from Taiwan and Hong Kong. In addition, since the research was completed about 50 years ago, the information is not up to date.

Chao Nancy Hao-Ming also wrote historical studies of Chinese art songs. In her dissertation Twentieth Century Chinese Vocal Music with Particular Reference to Its

\footnotetext{
${ }^{26}$ Meifeng Kang Chi, "A Performance Guide for Contemporary Chinese Art Songs from Taiwan" (Ed.D. diss., Teachers College, Columbia University,1996).

${ }^{27}$ Schuman Chuo Yang, "20th Century Chinese Solo Songs: A Historical and Analytical Study of Selected Chinese Solo Songs Composed and Arranged by Chinese Composers" (Ph.D., diss., George Peabody College for Teachers, Vanderbilt University, 1973).
} 
Development and Nationalistic Characteristics from the May Fourth Movement (1919) to 1945, she thoroughly discusses the history and the origin of Chinese art songs. ${ }^{28}$ She also analyzed music styles and compositions of three pioneer composers during this period. The scores and sound recordings of selected works are also provided. However, the book only included three composers: Zhao Yuanren, Huang Zi and Xian Xing Hai. In terms of scope, it is a general research, including all genres of Chinese vocal music. It was not specifically written for art songs.

Performance Guide of Chinese Art Songs by Mo Jigang was published in 2003. It has two parts: a historical review and a singing guide. ${ }^{29}$ The historical review includes both western art songs and Chinese art songs, providing information about the music style, characteristics, and important composers. The second part mainly presents musical analysis of selected folk songs and art songs with music scores (piano and voice edition). It was a very comprehensive performance guide for Chinese solo vocal music, including both folk and art songs. However, this guide does not provide enough reference information, like the level of difficulty and voice types. It was published in China and is not easily useable for non-Chinese singers.

The Guide of Chinese Art Songs is another guidebook for performance. ${ }^{30}$ Its purpose is to provide an introductory resource for singers. The authors, Zheng Jie, Zhao Li Ping, and Yang Mimi were professors from Hangzhou Normal University. They present the historical background of Chinese art songs in the 20th century, followed by a discussion of the

\footnotetext{
${ }^{28}$ Nancy Hao-Ming Chao, "Twentieth Century Chinese Vocal Music with Particular Reference to Its Development and Nationalistic Characteristics from the May Fourth Movement (1919) to 1945" (Ph.D., diss., University of California, Los Angeles, 1995).

29 Jigang Mo, Chinese Art Song Performance Guide [in Chinese], (Shanghai: Shanghai Music Publishing House, 2003).

${ }^{30} \mathrm{Jie}$ Zheng, Li Ping Zhao and Mimi Yang, Guide of Chinese Art Songs [in Chinese], (Shanghai: Shanghai Education Publishing House, 2009).
} 
establishment and style characteristics. The main part of the book is the analysis of songs, which are organized in chronological order. It provides poetry analysis along with music scores (for piano and voice). There is also a CD recording attached to the printed book. However, the number of songs were limited. Only 26 songs composed from 1920 to 1960 are selected. Additionally, the book was only published in China.

In the book, Music Appreciation and Analysis of Chinese Art Songs, Sun Yuemei and Liu Chang provides a brief history review and discusses the definition and characteristics of Chinese art songs during their early stage of development. ${ }^{31}$ The book also provides the biographies of 16 Chinese composers in the $20^{\text {th }}$ century. However, it is only available in Chinese and contains only 20 songs from the 20 th century.

Xue Qianghua wrote On the Development of Chinese Art Songs, in which he briefly introduces the development of Chinese art songs over the course of the 20 th century. ${ }^{32} \mathrm{He}$ outlines three stages: 1) Introduction and imitation in the 1920s, 2) learning and borrowing from 1930 to 1949, and 3) fusions and absorbing after 1950. In each stage, Xue discusses the general characteristics of the Chinese art songs in that period. He introduces important composers and their representative compositions and discussed other related topics, including the ethnic style, the utilization of Chinese poetry, and the usage of modern composition in Chinese art songs.

In Review of the Origin and Development of Art Song in China (1920-1949), Zeng Jinshou provided a detailed review of the Chinese art songs before $1949 .{ }^{33}$ Zeng examines the development

\footnotetext{
${ }^{31}$ YueMei Sun and Chang Liu, The Appreciation of Chinese Art Songs [in Chinese], (Hefei: An Hui Art Publishing House, 2015).

32 Qianghua Xue, "On the Development of Chinese Art Song" [in Chinese], Music \& performance/ Journal of Nanjing Arts Institute 99, no. 1 (January 2004):87-89.

33 Jinshou Zeng, "Review of the Origin and Development of Art Song in China (1920-1949)" [in Chinese], pts1,2, and 3, Jiao Xiang/ Journal of Xi'an Conservatory of Music 60, no. 2 (Summer 1993): 71-72; 61, no. 3 (Fall 1993): 7274; 62, no. 4 (Winter 1993): 56-57.
} 
of Chinese art songs in light of the social and political environment. He discusses the changing topics of Chinese music's ethnic songs and provided concrete examples of representative works to support his argument. He notes that Zhao Yuanren used folk tunes and spoken dialects to establish the ethnic style of Chinese art songs. For example, in "How Can I Keep from Thinking of You?" Zhao used a Chinese opera tune, and in "Fighting for China," Zhao used a Buddhist mantra tune of ghost festival. In conclusion, the works of Xue and Zeng are great resources for this study of the genre, although they were not intended to be used for the repertoire searching.

The review of the literature shows that there is a lack of study related to this topic. This suggests that this research will be a valuable study toward compiling a repertoire guide of Chinese art songs with an annotated bibliography. This study will provide a useful tool for teachers and scholars who are interested in Chinese art songs and culture. It may also be of interest to historians and literary scholars, particularly those interested in Chinese art and poetry. 


\section{Chapter III: Annotated Listing of Chinese Art Songs in the 1920s}

Composer: Chen Xiaokong (陈啸空, 1904-1953)

Piano arrangement: Zeng Lizhong (曾理中, 1926-1992)

Title: Xiang Lei (湘累, 1924)

Title Translation: Xiang's Weary

Publisher: People's Music

Poet: Guo Moruo (郭沫若, 1892-1978)

Poem style: Modern Chinese poetry

Difficulty level: Beginning level

Voice type: Soprano, mezzo-soprano

Tessitura: A3-E5

Duration: 4:00 mins

Voice characteristics: syllabic setting; mostly conjunct motion; limited dynamic requirement; fermata in the ending section; comfortable tessitura for beginning singers

Piano accompaniment: primarily blocked chords; double voice part; some arpeggiated passages in the left hand; easy rhythm and good support for the voice part

Comments: The song is written in ternary form. It is a commemoration for the ancient poet and politician Qu Yuan (c. 340-278 BC), who wrote the first poetry collection in the history of Chinese poetry. He is considered the first poet in China. ${ }^{34} \mathrm{He}$ died by jumping in the river in order to prove his loyalty to the country. The song mainly describes people calling and searching for his spirit. It expresses condolences to Qu Yuan. The piano accompaniment was later arranged by Zeng Lizhong.

34 "Qu Yuan," Britannica Academic, https://academic-eb-com.www.libproxy.wvu.edu/levels/collegiate/article/QuYuan/82499 (accessed October 14, 2019). 
Composer: Qing Zhu (青主, 1893-1959)

Title: Da Jiang Dong Qu (大江东去, 1920)

Title translation: The River Flowing to the East

Publisher: People's Music; Shanghai Educational

Poet: Su Shi (苏轼, 1037-1101)

Poem style: Classical Chinese poetry

Difficulty level: Intermediate level

Voice type: Tenor, baritone

Tessitura: D4-F\#5

Duration: 3:40 mins

Voice characteristics: in parlando style; speech-like rhythm; chanting feeling; some skips but mostly conjunct motion; sustained F\#5 and E5 as last notes in the middle section and the final section; many instructions for shades of dynamics and expressions

Piano accompaniment: choral patterns as well as arpeggiated patterns; right hand mostly doubles the vocal part; repeated rhythm pattern in sixteenth notes with blocked chords in the interlude

Comments: It is recognized as the first Chinese art song. Qing Zhu composed it in his college year at Berlin University in $1912 .{ }^{35}$ The poet, Su Shi, describes the magnificent scenery on the river and crafts a memory of the heroes of the Three Kingdoms period. This serves as a metaphor of his middle-aged grievances and unsuccessful political dream. The poem is full of the regrets and pities of life.

${ }^{35}$ YueMei Sun and Chang Liu, The Appreciation of Chinese Art Songs [in Chinese], (Hefei: An Hui Art Publishing House,2015), 21. 
Composer: Qing Zhu (青主, 1893-1959)

Title: Wo Zhu Changjiang Tou (我住长江头, 1930)

Title translation: I Live Near the Source of the Changjiang ${ }^{36}$ River

Publisher: People's Music; Shanghai Educational

Poet: Li Zhiyi (李之仪, 1038-1117)

Poem style: Classical Chinese poetry

Difficulty level: Intermediate level

Voice type: Soprano, mezzo-soprano, tenor

Tessitura: D4-A5

Duration: 2:07mins

Voice characteristics: Flowing, legato, and sweeping phrases; syllabic setting; some accidentals; A5 appears several times, but not sustained; the long high notes on G5 appears multiple times in the end; technically need good breathing control; the tempo is marked "Allegro ma non troppo," so ensure that you do not sing it too quickly

Piano accompaniment: arpeggiated pattern in sixteenth notes throughout the song; depicting the flowing river; blocked chords in the final section; Qing stated one may play the piano to sound like a harp with gentleness and legato in the original score ${ }^{37}$

Comments: Qing Zhu did not intend to write this song for love. His real name was Liao Shangguo. He was very active in a protest organization that opposed the military power of the government. After the failure of the Great Revolution of 1927, Qing Zhu began his life of escape. Then he started to use the name of Qing Zhu as a pseudonym to cover up his identity. He wrote this song to secretly commemorate his comrades in battle, implicitly expressing his trauma and frustration. Based on this historical context, singers should try to express a heavy and helpless emotion, instead of carrying the light and passionate feelings associated with love. ${ }^{38}$

\footnotetext{
${ }^{36}$ Changjiang ( 长江), also called the Yangtze River, which is the longest river in China. Many poets wrote poems about it over several centuries.

${ }^{37}$ Changli Zhu, "The Features of the Piano Accompaniments of Qing Zhu's Art Songs based on Classical Chinese poetry" [in Chinese], Jiaoxiang/ Journal of Xi'an Conservatory of Music 33, no. 4 (December 2014): 123. ${ }^{38}$ Jigang Mo, Chinese Art Song Performance Guide [in Chinese], (Shanghai: Shanghai Music Publishing House, 2003), 36.
} 
Composer: Xiao Youmei (萧友梅, 1884-1940)

Title: Wen (问, 1922)

Title translation: Question

Publisher: People's Music; Shanghai Educational

Poet: Yi Weizhai (易韦斋, 1874-1941)

Poem style: Modern Chinese poetry

Difficulty level: Beginning level

Voice type: All types

Tessitura: D4-E5

Duration: 2:30mins

Voice characteristics: some upward leaps; some ascending passages; triplets; needs gentle and legato singing; primarily syllabic setting with some melismatic passages; simple rhythm; good harmonic support by the piano

Piano accompaniment: blocked chordal patterns, repeated notes in the left hand; double voice part in the right hand

Comments: It is a very simple and short song. This composition is very representative of Xiao Youmei's work. In the 1920s, the warlord divided China into different regions causing the melee. ${ }^{39}$ This song expresses Xiao's worries for the people and country during this dark time.

${ }^{39}$ Yuhe Wang, The History of Modern Chinese Music [in Chinese], (Beijing: People's Music Publishing House, 2009), 84. 
Composer: Zhao Yuanren (赵元任, 1892-1982)

Title: Shang Shan (上山, 1926)

Title translation: Climbing the Mountain

Publisher: Shanghai Educational; People's Music

Poet: Hushi (胡适, 1891-1962)

Poem style: Modern Chinese poetry

Difficulty level: Intermediate level

Voice type: All types

Tessitura: D4-G5

Duration: 4:08mins

Voice Characteristics: recitative-like; many dotted rhythms and repeated notes to imitate speech; both conjunct and disjunct motion; some wide leaps including octaves and sevenths; triplets and duplets; many descriptions for dynamics and expressions

Piano accompaniment: prelude, interlude, and postlude; double voice part and very supportive; some blocked chords; some broken chord figures

Comments: It is a song full of hope and encouragement. Through the intentional use of rhythm and texture, the music works to depict the image of climbing a mountain. The lyrics tell a very narrative story, including verbal encouragement to himself, specific mountain climbing details, and scenery of different heights of the mountain. It starts on Bb Major mode and ends on B major mode, which expresses the contrasting moods between the difficulty of climbing the mountain versus the joy of the view from the peak. 
Composer: Zhao Yuanren (赵元任, 1892-1982)

Title: Ting Yu (听雨, 1927)

Title translation: Listening to the Rain

Publisher: People's Music; Shanghai Educational

Poet: Liu Bannong (刘半农, 1891-1934)

Poem style: Modern Chinese poetry

Difficulty level: Beginning level

Voice type: All types

Tessitura: C4-Eb5

Duration: 1:53 mins

Voice characteristics: simple and short; stepwise and wide descending leaps (in sixths and sevenths); independent from piano; some words hard to project like "Sun (笋)" and "Xu(许)"

Piano accompaniment: the raining sound imitated by repeated eighth notes throughout the song; repeated chords in the left hand; very depictive rhythm and melody

Comments: The music imitates the chanting tones of the Classical Chinese poetry read by people from Changzhou (常州) in Jiangsu province. ${ }^{40}$ The Changzhou dialect belongs to $\mathrm{Wu}$ Chinese which is an ancient dialect has lasted for 3000 thousand years. It has invaluable historical value. The dialect kept the ancient tones and word choices closet to the ancient Chinese.

${ }^{40}$ RenKang Qian, "Analysis of Songs Composed by Zhao Yuanren” [in Chinese], Musicology in China no. 1, (January 1988): 8. 
Composer: Zhao Yuanren (赵元任, 1892-1982)

Title: Jiao Wo Ru He Bu Xiang Ta (教我如何不想他, 1926)

Title translation: How Can I Keep from Thinking of You?

Publisher: People's Music; Shanghai Educational

Poet: Liu Bannong (刘半农, 1891-1934)

Poem style: Modern Chinese poetry

Difficulty level: Intermediate level

Voice type: All types

Tessitura: D4-F\#5

Duration: 4:11 mins

Voice Characteristics: both conjunct and disjunct motion; some ascending passages in small skips; upward octave leaps in the end; some accidentals; harmonically supported by the piano

Piano and violin accompaniment: blocked and broken chords; sustained note in the left hand; easy rhythm; violin part in the score ${ }^{41}$

Comments: It is important to mention here the contrasted usages of the characters "她 (pronounces as ta, meaning she)" and “他 (pronounces as $t a$, means him or her)" in the title of the poem and the song. The poet Liu Bannong wrote the poem "Jiao Wo Ru He Bu Xiang Ta" (教我如何不想她, How Can I Keep from Thinking of Her?) in 1920. In the poem title, the character “她 ( $t a)$ ” means "her." It was invented by Liu for this poem because it was written for his lover. During that time, there was no specific character especially for "her (她, $t a$ )" in Chinese literature. Both "her" and "him" were written as 他 $(t a) .{ }^{42}$ However, while writing the song, Zhao Yuanren changed the character “她 (ta, means she)” into “他 (ta, him or her)”. So, the song title was altered to “Jiao Wo Ru He Bu Xiang Ta” (教我如何不想他, How Can I Keep from Thinking of You (means Him or Her?). He made the change to give the song a new meaning, which was to express general love, not only for the special lover. So, singers need to consider the intention of general love for the mood of the song, not singing it only as a love song. From the Chinese ethnic aspect, this song was a very good example of adding ethnic elements

\footnotetext{
${ }^{41}$ This is one of the chamber versions of art songs that are included in the research. The violin functions in a supportive role harmonically.

${ }^{42}$ Li Wang, Chinese Classical Art Song 1920-1949, Volume One [in Chinese], (Beijing: People's Music Publishing House, 2015), 11.
} 
into art songs. Zhao borrowed the typical tune of the Chinese Opera prelude "Xipi" and used it in the beginning parts of the song. ${ }^{43}$

43 Jigang Mo, Chinese Art Song Performance Guide [in Chinese], (Shanghai: Shanghai Music Publishing House, 2003), 22. 
Composer: Zhao Yuanren (赵元任, 1892-1982)

Title: Qiu Zhong (秋钟, 1922)

Title translation: The Autumn Bell

Publisher: People's Music

Poet: Zhao Yuanren (赵元任, 1892-1982)

Poem style: Modern Chinese poetry

Difficulty level: Beginning level

Voice type: All types

Tessitura: D4-F5

Duration: 1:40 mins

Voice Characteristics: short phrases; stepwise and chordal skips; several accidentals; syllabic setting; simple rhythm and easy dynamic

Piano accompaniment: ostinato patterns mostly throughout; quick scale passages in sixteenths; 3 voice texture; harmonically supportive to voice part

Comments: Zhao wrote both the lyrics and the music for this song. The textures of the piano part represent different nature sounds, such as the wind sound, bell sound, and falling leaves sound. He also made a note especially for making the sound effect of the bell. He gives some specific explanations of the usage of the pedal in the original score. It mentioned the player needs to push down on the pedal for the repeated note and follow the dynamic mark as ">". One should play loudly on ">" and play very softly the note after it. ${ }^{44}$

\footnotetext{
${ }^{44}$ Li Wang, Chinese Classical Art Song 1920-1949, Volume One [in Chinese], (Beijing: People's Music Publishing House, 2015), 5.
} 
Composer: Zhao Yuanren (赵元任, 1892-1982)

Title: Mai Bu Yao (卖布谣, 1922)

Title translation: Fabric Selling Ballad

Publisher: People's Music

Poet: Liu Da Bai (刘大白, 1880-1932)

Poem style: Modern Chinese poetry

Difficulty level: Beginning level

Voice type: All types

Tessitura: C4-F5

Duration: 0:50 mins

Voice Characteristics: small skip, upward motion; many notes on Eb5 and F5; syllabic setting; short phrases; 4/5-meter, typical Chinese chanting rhythm; written in the Chinese pentatonic mode

Piano accompaniment: supportive to the voice part; double the voice part in the right hand; repeated pattern in the left hand

Comments: The poem "Mai Bu Yao" was first published in 1920. The song was popular back at the time ${ }^{45}$ It is short and simple. The main narrator is a small child who describes the pitiful life of the common craftsman.

${ }^{45}$ Jigang Mo, Chinese Art Song Performance Guide [in Chinese], (Shanghai: Shanghai Music Publishing House, 2003), 23. 
Composer: Zhao Yuanren (赵元任, 1892-1982)

Title: Ye Shi Wei Yun (也是微云, 1926)

Title translation: Also, Are the Smallest Clouds

Publisher: Shanghai Educational

Poet: Hu Shi (胡适, 1891-1962)

Poem style: Modern Chinese poetry

Difficulty level: Intermediate

Voice type: All types

Tessitura: A3-F5

Duration: 2:15 mins

Voice Characteristics: many passages in melismatic settings; wide leaps in sixth and octave; triplets and syncopation; sustained note on F5 and E5; calm and quiet mood; description for the time in the past

Piano accompaniment: short prelude and postlude; blocked chords; harmonically supportive to the voice part

Comments: It is a short and through-composed song. It is mainly about missing old friends in the past. It is a typical poem that uses the descriptions of the scenery as a channel to express personal feelings. 


\section{Chapter IV: Annotated Listing of Chinese Art Songs in the 1930s}

Composer: Chen Tianhe (陈田鹤, 1911-1955)

Title: Chun Gui He Chu (春归何处, 1931)

Title translation: Where does Spring Belong

Publisher: People's Music; Shanghai Educational

Poet: Huang Tingjian (黄庭坚, 1045-1105)

Poem style: Classical Chinese poetry

Difficulty level: Intermediate level

Voice type: All types

Tessitura: $\mathrm{Bb} 3-\mathrm{Eb}$

Duration: $1: 17 \mathrm{mins}$

Voice characteristics: chordal skips; many wide leaps in intervals of sixths and octaves; easy rhythm; limited dynamic range; contrasted mood in two different sections; few accidentals

Piano accompaniment: slow rhythmic motion; broken chord patterns; doubles the voice part; many octaves played by the left hand

Comments: Huang Tingjian was a poet and a calligraphy master in the Song dynasty (9601279). Chen Tianhe was a composition student of Huang $\mathrm{Zi}$. Chen composed more than 100 songs in his lifetime. Many of his works were written in a simple and delicate style. Chen believed that composers must consider the original poem's form and content when setting poetry to music. ${ }^{46}$

${ }^{46}$ YueMei Sun and Chang Liu, The Appreciation of Chinese Art Songs [in Chinese], (Hefei: An Hui Art Publishing House,2015),150. 
Composer: Chen Tianhe (陈田鹤, 1911-1955)

Title: Shan Zhong (山中, 1934)

Title translation: In the Mountain

Publisher: People's Music

Poet: Xu Zhi Mo (徐志摩, 1903-1987)

Poem style: Modern Chinese poetry

Difficulty level: Intermediate level

Voice type: All types

Tessitura: C3-E4

Duration: 2:28mins

Voice characteristics: many chordal skips; some wide leaps in intervals of sixths and sevenths; some accidentals; triplets and dotted rhythms; changing tempos from Andante to Allegretto

Piano accompaniment: Changing textures from blocked chords in triplets to arpeggiated running notes; melody line independent from the voice part; harmonically supportive to the voice part; uses full keyboard

Comments: Chen set this song into two distinct sections based on the structure of the poem. $\mathrm{He}$ creates the contrasts between the two sections through diverse moods, tempos, dynamics, and textures. The piano accompaniment plays a vital role by serving as the background and creating the shifting of the moods. It also has an independent melody which echoes the voice part. 
Composer: Chen Tianhe (陈田鹤, 1911-1955)

Title: Qiu Tian de Meng (秋天的梦, 1936)

Title translation: Autumn's Dream

Publisher: Shanghai Conservatory of Music Press

Poet: Dai Wangshu (戴望舒, 1905-1950)

Poem style: Modern Chinese poetry

Difficulty level: Intermediate level

Voice type: All types

Tessitura: C4-E5

Duration: 2:28mins

Voice characteristics: Chordal skips and sweeping melody; two-note slurs; many phrases begin on the afterbeats; comfortable tessitura; limited dynamic range

Piano accompaniment: triplets in sixteenth notes; sustained chords in the left hand; staccatos; harmonically supports the voice part; doubles the voice part in the end

Comments: "Qiu Tian de Meng" is written by Dai Wangshu, a modern poet from the early $20^{\text {th }}$ century who wrote symbolically. It is a representative poem of his early works. Many of them portray a touch of sadness. Chen Tianhe composed this song in 1936. Since it is a symbolic poem, the singer needs to have a good interpretation of the poem's meaning. 
Composer: Chen Tianhe (陈田鹤, 1911-1955)

Title: Cai Sang Qu (采桑曲, 1930s)

Title translation: The Song of Picking Mulberry Leaves

Publisher: People's Music

Poet: Zheng Qi (郑起, 1199-1262)

Poem style: Classical Chinese poetry

Difficulty level: Beginning level

Voice type: All types

Tessitura: B3-E5

Duration: 00:40mins

Voice characteristics: stepwise and small skips; syllabic setting; short phrases; easy word projection; easy rhythm; limited dynamic range; beginner song

Piano accompaniment: very supportive to the voice part; doubles the voice throughout; linear texture; simple blocked chords; slow rhythmic motions

Comments: Zheng Qi is a scholar of Chinese Literature from the Song dynasty. "Cai Sang Qu" describes a farmer's life. Their daily life consists of picking mulberry leaves and making mulberry silk. Even though they make silk clothes, they can only afford to wear linen. The song was written simplistically with a calm mood and a touch of sadness. 
Composer: He Luting (贺绿汀, 1903-1999)

Title: Jialing Jiang Shang (嘉陵江上, 1939)

Title translation: On the Jialing River

Publisher: People's Music

Poet: Duan Mu Hong Liang (端木蕻良, 1912-1996)

Poem style: Modern Chinese poetry

Difficulty level: Intermediate level

Voice type: Baritone, tenor

Tessitura: B3-F\#5

Duration: 3:10mins

Voice Characteristics: stepwise and small skips; parlando style; upward leaps in intervals of sixths; triplets and trills; many phrases start on the afterbeat

Piano accompaniment: prelude; sustained chords; octaves; some broken chord figures; call and response passages; harmonically supportive to the voice part

Comments: This is a recitative-like art song. He Luting uses dotted rhythm and triplets to reflect the natural word-like inflection. The lyrics are very expressive and attempt to tell a story. It is a typical anti-war song and remains very popular. ${ }^{47}$

${ }^{47}$ Yuhe Wang, The History of Modern Chinese Music [in Chinese], (Beijing: People's Music Publishing House, 2009), 193. 
Composer: Huang Zi (黄自, 1904-1953)

Title: Meigui San Yua (玫瑰三愿, 1932)

Title Translation: The Three Wishes of the Rose

Publisher: People's Music

Poet: Long Qi (龙 t $^{48}$, 1902-1966)

Poem style: Modern Chinese poetry

Difficulty level: Intermediate level

Voice type: Soprano, mezzo-soprano

Tessitura: B3-G\#5

Duration: 2:44 mins

Voice characteristics: conjunct and disjunct motions; many skips, some leaps in sevenths and octaves; sustained notes on G\#5 and D4 in one phrase; contrasted dynamics; short phrases in the beginning written with dotted rhythms for imitating speech; lyrical and long phrases in the second part; not for beginning singers

Piano and violin accompaniment: blocked chords; some arpeggiated passages in the left hands; harmonically supportive to the voice part; has a prelude together with violin; violin part is very independent, and playing duet with the voice part throughout the song

Comments: "Three Wishes of the Rose" is a through-composed song. The rose is an anthropomorphic character. It speaks for most of the women's voices. It gave three wishes for staying away from the pain and maintaining the beauty forever.

\footnotetext{
${ }^{48}$ Long Qi, original name is Long Yusheng (龙榆生), is an important literature scholar and a master of Lyric (Ci) poetry in $20^{\text {th }}$ century China.
} 
Composer: Huang Zi (黄自, 1904-1953)

Title: Si Xiang (思乡,1932)

Title Translation: Homesick

Publisher: People's Music

Poet: Wei Hanzhan (韦瀚章, 1905-1993)

Poem style: Modern Chinese poetry

Difficulty level: Intermediate level

Voice type: All types

Tessitura: C4-G5

Duration: 1:59 mins

Voice characteristics: considerable chromatics; accidentals in the beginning of the phrase; angular melody line; mostly syllabic setting with some ornamented writings; easy dynamic control; not easy for ensemble; not for beginning singer

Piano accompaniment: linear texture in the first part and blocked of chords in the second; piano has an independent melody line in the first part; supportive to singer in the second part; short prelude and interlude

Comments: Wei Hanzhang was the first generation of poets to write lyrics for modern Chinese songs. ${ }^{49}$ "Si Xiang" (homesick) was his first attempt for writing this type of lyrics. Wei Hanzhang and the composer, Huang $\mathrm{Zi}$, were colleagues that both worked in Shanghai Music Conservatory. Later, Huang composed more songs based on Wei's lyrics. These songs included the "Chun Si Qu" (Song of Spring Thoughts) which is analyzed in the following entry. ${ }^{50}$

${ }^{49}$ Li Wang, Chinese Classical Art Song 1920-1949, Volume One [in Chinese], (Beijing: People's Music Publishing House, 2015), 61.

${ }^{50}$ Jigang Mo, Chinese Art Song Performance Guide [in Chinese], (Shanghai: Shanghai Music Publishing House, 2003), 50. 
Composer: Huang Zi (黄自, 1904-1953)

Title: Chun Si Qu (春思曲, 1932)

Title Translation: Song of Spring Thoughts

Publisher: People's Music

Poet: Wei Hanzhang (韦瀚章, 1905-1993)

Poem style: Classical Chinese poetry

Difficulty level: Intermediate level

Voice type: Soprano, Mezzo-soprano

Tessitura: C4-G5

Duration: 2:29 mins

Voice characteristics: considerable chromatics; flowing melody line and many wide leaps in sixths and octaves; long phrases, needs good breath control; some hard word projections, like "xiao" and "zhi"; dreamy, floating mood

Piano accompaniment: repeated chordal patterns in the right hand; arpeggiated patterns with chromaticism; need to play gently and softly, as "sempre delicato" (always delicate) noted in the beginning; supportive piano accompaniment

Comments: This is a modern poem that was written in the form of classical Chinese poetry. Both Huang's songs "Si Xiang" and "Chun Xi Qu" express loneliness, emptiness, and a floating mood. 
Composer: Huang Zi (黄自, 1904-1953)

Title: Hua Fei Hua (花非花, 1933)

Title Translation: Flowers are not Flowers

Publisher: People's Music

Poet: Bai Juyi (白居易, 772-846)

Poem style: Classical Chinese poetry

Difficulty level: Beginning level

Voice type: All voice types

Tessitura: B3-E5

Duration: 1:50 mins

Voice characteristics: syllabic setting; mostly conjunct motion with some wide skips; short phrases; comfortable tessitura for beginner; easy dynamic; gentle and soft singing

Piano accompaniment: 3 voice texture; very supportive to the voice part, double voice line; short prelude; simple rhythm

Comments: The poet Bai Juyi is a prestigious poet and scholar in the history of Chinese literature. The poetry expresses the meanings of Zen. Through the description of the changing scenery, it reveals the impermanence of a person's life and implies that any life change is just a dream. The song is short and simple. The mood is lighthearted. 
Composer: Huang Zi (黄自, 1904-1953)

Title: Ta Xue Xun Mei (踏雪寻梅, 1933)

Title Translation: Stepping in the Snow to Find Plums

Publisher: People's Music

Poet: Liu Xue’an (刘雪庵, 1905-1985)

Poem style: Classical Chinese poetry

Difficulty level: Beginning level

Voice type: All voice types

Tessitura: B3-E5

Duration: 00:40 mins

Voice characteristics: syllabic setting; many skips; repeated staccatos; short phrases; angular melodic line; comfortable tessitura for beginners; easy rhythm

Piano accompaniment: repeated staccato patterns; blocked chords and octaves; easy rhythm; harmonically supportive to the voice part

Comments: Liu Xue'an is a student of Huang $\mathrm{Zi}$ in music composition. He is also a poetry student of Long Qi, who is one of the Chinese poetry masters in the $20^{\text {th }}$ century. The poem embodies the experiences of youth. It describes the life of being young and carefree. As a result, it expresses a lighthearted and happy mood. 
Composer: Huang Zi (黄自, 1904-1953)

Title: Xi Feng de Hua (西风的话, 1934)

Title Translation: The Words of the West Wind

Publisher: People's Music

Poet: Liao Fushu (廖辅叔,1907-2002)

Poem style: Modern Chinese poetry

Difficulty level: Beginning level

Voice type: All voice types

Tessitura: B3-C\#5

Duration: 1:04 mins

Voice characteristics: stepwise melody with few skips; syllabic setting; easy rhythm; simple dynamic; very good selection for beginners

Piano accompaniment: right hand doubles the voice part throughout the song; linear texture; hymn-like accompaniment; easy rhythm

Comments: The poet Liao Fushu is the younger brother of Qing Zhu (Liao Shangguo), as mentioned in the previous chapter. In the poem, the poet personified the west wind. The west wind compares the growth of children with the beauty of growing the plants. This song was originally written for a middle-school music textbook in 1930s. ${ }^{51}$ It is very simple and easy to sing.

${ }^{51}$ Li Wang, Chinese Classical Art Song 1920-1949, Volume One [in Chinese], (Beijing: People's Music Publishing House, 2015), 71. 
Composer: Huang Zi (黄自, 1904-1953)

Title: Nan Xiang Zi, Deng Jing Kou Beigu Ting You Huai (南乡子・登京口北固亭有怀, 1934)

Title Translation: Nan Xiang Zi, Having Thoughts while Boarding Beigu Pavilion at the City of Jing Kou

Publisher: People's Music

Poet: Xin Qiji (辛弃疾, 1140-1207)

Poem style: Classical Chinese poetry

Difficulty level: Beginning level

Voice type: Baritone, tenor

Tessitura: C4-E5

Duration: 1:54 mins

Voice characteristics: chordal skips with wide leaps in octaves; syllabic setting; dotted rhythms for a speaking effect; harmonically supported by the piano

Piano accompaniment: repeated blocks of chords in triplets throughout the song; slower rhythmic motion; few accidentals; double vocal line in right hand

Comments: "Nan Xiang Zi" is a type of lyric title $(\mathrm{Cipai})^{52}$ for writing lyric $(\mathrm{Ci})$ poetry for the existing melodies. The earliest lyric title (Cipai) was emerged in the Tang dynasty (618-907) and continued to the Song dynasty (960-1279). During that time, the poems were always used together with certain melodies. The Poet, Xin Qiji, was famous for his patriotic poems. This poem was written when he was boarding at the Beigu pavilion, which was located at the border of his country. He used this poem to satirize the government at the time and praise the heroes of the Three Kingdoms period in the past.

\footnotetext{
${ }^{52} \mathrm{Ci}$ poetry has restricted patterns called Cipai. There are around eight hundred Cipai. Poets uses Cipai as rules to compose new poems. They are required to use certain number of words and specific arrangement of rhymes for each line. There are also certain sequences of tones for the words.
} 
Composer: Huang Zi (黄自, 1904-1953)

Title: Dian Jiang Chun, Fu Deng Lou (点㖓唇・赋登楼, 1934)

Title Translation: Dian Jiang Chun, Ode to Ascending the Tower

Publisher: People's Music

Poet: Wang Zhuo (王㷋 $5^{3}$ )

Poem style: Traditional-style poetry

Difficulty level: Intermediate level

Voice type: All types, but more often baritones

Tessitura: B3-E5

Duration: 2:06 mins

Voice characteristics: syllabic setting with some melismatic passages; stepwise melody with some wide skips; ornamented notes; dotted rhythm; harmonically supported by the piano

Piano accompaniment: repeated blocked chords on the left hand; ostinato patterns; doubles the voice line on the right hand; brief prelude, interlude and postlude; many repeated patterns; slow motion of rhythms

Comments: "Dian Jiang Chun" is another type lyric title (Cipai) of Lyric (Ci) poetry, like the "Nan Xiang Zi," which has been mentioned in the last song. This poem is written by Wang Zhuo, a poet that knows both poem and music very well. He is a famous scientist and scholar of Chinese literature and music in the Song Dynasty (960-1279).${ }^{54}$ This poem expresses the love and praise for the great scenery of the country.

\footnotetext{
${ }^{53}$ The born and death date of the poet, Wang Zhuo, is unknown. He was a famous scholar of science and literature in Song Dynasty (960-1279).

${ }^{54}$ Mimi Yang, Jie Zheng, and Liping Zhao, Chinese Art Song Tutorial [in Chinese], (Shanghai Educational Publishing House, 2009), 76.
} 
Composer: Jiang Dingxian (江定仙, 1912-2000)

Title: Sui Yue You You (岁月悠悠 1936)

Title translation: Years Long ago

Publisher: Shanghai Educational

Poet: Huang Jiamo (黄嘉谟, 1916-2004)

Poem style: Classical Chinese poetry

Difficulty level: Intermediate level

Voice type: Soprano, Tenor

Tessitura: Db4-Ab5

Duration: 02:45mins

Voice characteristics: long, flowing, and sweeping phrases; syllabic setting; stepwise and small skips; in Chinese pentatonic mode; slow rhythmic motion; limited dynamic range; easy rhythm

Piano accompaniment: very long prelude; a solo passage; blocks of chords; call and response passages with the voice; relatively independent

Comments: Jiang Dingxian wrote many art songs in his lifetime. "Sui Yue You You" was one of his early works. It was lyrical and expressive. It mainly described his thoughts about the past and his mourning that those times can never come back. 
Composer: Jiang Wenye (江文也, 1910-1983)

Title: Shang Chun (伤春, 1939)

Title translation: Sad Spring

Publisher: Shanghai Educational

Poet: Wang Anshi (王安石, 1021-1085)

Poem style: Classical Chinese poetry

Difficulty level: Intermediate level

Voice type: All types

Tessitura: C4-F5

Duration: 03:08 mins

Voice characteristics: Flowing and sweeping melody; stepwise and small skips; several downward leaps in sixths; syllabic setting; limited dynamic range

Piano accompaniment: very long prelude as solo passages; 3 voice texture; has an independent melody line; double the voice line; blocked chords in wide range; repeated rhythmic pattern in the left hand throughout;

Comments: Jiang Wenye was a prolific composer from the 20th century. In the 1940s, he wrote many Chinese art songs based on classical Chinese poetry. However, it was never collected or published during his lifetime. ${ }^{55}$ "Sad Spring" is a lyric ( $\mathrm{Ci}$ ) poem written by Wang Anshi, a renowed poet from the Song Dynasty. Through the description of the spring scenery, Wang expressed his longing for the past.

${ }^{55}$ Yuhe Wang, The History of Modern Chinese Music [in Chinese], (Beijing: People's Music Publishing House, 2009), 270. 
Composer: Lao Zhicheng (老志诚, 1910-2006)

Title: Leifeng Ta Ying (雷锋塔影, 1932)

Title translation: The Shadow of Leifeng Tower

Publisher: Shanghai's Educational

Poet: Xu Zhi Mo (徐志摩, 1903-1987)

Poem style: Mordern-style poetry

Difficulty level: Intermediate level

Voice type: Soprano, Tenor

Tessitura: C4-A5

Duration: 2:20mins

Voice characteristics: stepwise and chordal skips; melismatic setting in the middle section; contrasted dynamics; coloratura passage in running notes with no accompaniment

Piano accompaniment: linear texture; arpeggiated passages; trills; quick running arpeggios in sixteenth notes; harmonically supported to the voice part

Comments: The "Leifeng Tower" is related with the Legend of the White Snake. It reveals a tragic love story of a snake spirit and a human. Lao Zhicheng is a Chinese pianist and composer from the $20^{\text {th }}$ century. 
Composer: Lin Shengxi (林声翕, 1914-1991)

Title: Bai Yun Gu Xiang (白云故乡,1938)

Title translation: White Cloud and Hometown

Publisher: People's Music

Poet: Wei Hanzhang (韦瀚章, 1905-1993)

Poem style: Modern Chinese poetry

Difficulty level: Intermediate level

Voice type: All types

Tessitura: D4-G5

Duration: 02:31mins

Voice characteristics: stepwise and some wide leaps; accidentals; fairly easy rhythm; syllabic setting; limited range of dynamics; sustained ending note on G5

Piano accompaniment: short prelude with solo voice; some arpeggiated passages; triplets of blocked chords; repeated octaves; harmonically supportive to the voice part

Comments: It is a popular anti-war song. It describes a traveling man's determination to protect his hometown against the war. Lin Shengxi wrote many vocal works including oratorios, operas, and art songs. He believed that musical works need to reflect the current time. He wrote "Bai Yun Gu Xiang" in 1938 after the WWII began in China. 
Composer: Li Weining (李惟宁, 1910-1985)

Title: Ou Ran (偶然, 1937)

Title translation: By Chance

Publisher: People's Music

Poet: Xu Zhi Mo (徐志摩, 1903-1987)

Poem style: Modern Chinese poetry

Difficulty level: Intermediate level

Voice type: All types

Tessitura: Eb4-G5

Duration: 2:11mins

Voice characteristics: Flowing and legato phrases; syllabic setting; stepwise and chordal skips; some wide leaps in sixteenth notes; some accidentals; easy rhythm; symmetrical phrases; limited dynamic range; harmonically supported by the piano

Piano accompaniment: arpeggiated patterns with sustained bass notes; blocks of chords written in a staccato style; different textures in the middle section

Comments: The poet, Xu Zhi Mo, is a pioneer of the Chinese New Poetry movement in the early $20^{\text {th }}$ century. He wrote the poem "By Chance" in 1926. Then, Li Weining wrote the music for the song in 1937. 
Composer: Lin Shengxi (林声翕, 1914-1991)

Title: Wang Yun (望云,1938)

Title translation: Watch the Clouds

Publisher: SLCM

Poet: Yu Jingshan (余景山, 1916-2004)

Poem style: Modern Chinese poetry

Difficulty level: Beginning/ intermediate level

Voice type: Soprano, Tenor

Tessitura: C4-A5

Duration: 03:04 mins

Voice characteristics: flowing and lyrical; syllabic setting; many skips; angular melody line; quick passing notes on A5; limited dynamic range; easy rhythm

Piano accompaniment: broken chord patterns; doubles the voice part; changing textures; chordal patterns in dotted rhythms

Comments: "Wang Yun" is a lyrical and gentle song. It is a typical love song which express romantic feelings. It is also one of Lin Shengxi's early vocal works. 
Composer: Liu Xue'an (刘雪庵, 1905-1985)

Title: Piao Ling de Luo Hua (飘零的落花, 1935)

Title translation: The Falling Flowers

Publisher: People's Music

Poet: Liu Xue'an (刘雪庵, 1905-1985)

Poem style: Classical Chinese poetry

Difficulty level: Intermediate level

Voice type: Soprano, mezzo-soprano

Tessitura: C4-G5

Duration: 2:33mins

Voice characteristics: stepwise and small skips; syllabic setting; many phrases in ascending motion; limited dynamic range; easy rhythm

Piano accompaniment: prelude and interlude; double the vocal part; sustained chords; calm and gentle; consistent accompaniment pattern throughout

Comments: Liu Xue'an wrote both the lyrics and the melody of this song. This song is typical of his early works. Most of them are simple, lyrical, and without dramatic expression. Liu was a student of Huang $\mathrm{Zi}$. Huang $\mathrm{Zi}$ gave him the inspiration to compose Chinese art songs based on the classical Chinese poetry. ${ }^{56}$

${ }^{56}$ Yuhe Wang, The History of Modern Chinese Music [in Chinese], (Beijing: People's Music Publishing House, 2009), 163. 
Composer: Liu Xue'an (刘雪庵, 1905-1985)

Title: Chang Cheng Yao (长城谣, 1937)

Title translation: The Ballad of the Great Wall

Publisher: People's Music

Poet: Pan jienong (潘子农, 1909-1993)

Poem style: Modern Chinese poetry

Difficulty level: Beginning level

Voice type: All types

Tessitura: D4-F5

Duration: 2:50 mins

Voice characteristics: stepwise and small skips; syllabic setting; limited dynamic range; easy rhythm; downward leaps in sixteenth notes; symmetrical phrases

Piano accompaniment: prelude and interlude; doubles the vocal part; sustained chords; calm and gentle; consistent accompaniment pattern throughout

Comments: This was a popular anti-war song from the 1930s. Later, it became a classic selection in Chinese art song repertoire. Most anti-war songs employed angular motions, a wide dynamic range, and contrasted musical textures in order to express dramatic and intense emotions. Unlike typical anti-war songs, "Chang Cheng Yao" utilized conjunct motions, a limited dynamic range, and linear music textures. This created a calm and peaceful mood. 
Composer: Liu Xue'an (刘雪庵, 1905-1985)

Title: Zhui Xun (追寻, 1938)

Title translation: The Pursuit

Publisher: Shanghai Educational

Poet: Xu Jianwu (许建吾, 1903-1987)

Poem style: Modern Chinese poetry

Difficulty level: Beginning level

Voice type: All types

Tessitura: C4-G5

Duration: 2:41mins

Voice characteristics: Flowing, legato, and sweeping phrases; stepwise and small skips in the melody; some ornaments to imitate Chinese speaking tunes; syllabic setting; easy rhythm; limited dynamic range; harmonically supported by the piano

Piano accompaniment: arpeggiated pattern in eighth notes throughout the song; linear texture; sustained octaves in the left hand; quick scale passages in the 32nd notes in the prelude

Comments: The poet Xu Jianwu wrote many expressive poems during his lifetime. During World War Two in China, Xu wrote the poem "Zhui Xun". The poem expressed his hope for the

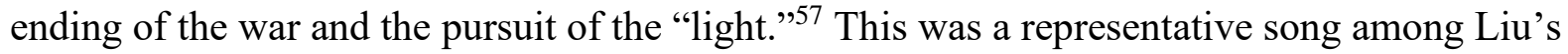
works. Most of the phrases were symmetrical. The melody was very simple and lyrical. The pentatonic mode added more ethnic feeling. The mood portrayed hopefulness.

${ }^{57}$ Li Wang, Chinese Classical Art Song 1920-1949, Volume One [in Chinese], (Beijing: People's Music Publishing House, 2015), 119. 
Composer: Lu Huabai (陆华柏, 1914-1994)

Title: Gu Xiang (故乡,1937)

Title translation: Hometown

Publisher: People's Music

Poet: Zhang Anzhi (张安治 ${ }^{58}$, 1911-1990)

Poem style: Modern Chinese poetry

Difficulty level: Intermediate level

Voice type: All types

Tessitura: A3-G5

Duration: 03:20 mins

Voice characteristics: stepwise and small skips; upward leaps in intervals of sixths and octaves; some phrases begin on the afterbeat; dotted rhythms; triplets; syllabic setting; contrasting dynamics; sustained note on F\#5

Piano accompaniment: quick running sixteenth notes; uses full keyboard; arpeggiated passages; many octaves; contrasting dynamics; doubles the voice part; some call and response passages; harmonically supportive to the voice

Comments: Zhang Anzhi was a very talented Chinese painter and poet. Lu Huabai was a Chinese composer and music educator. In addition to Chinese art songs, he also wrote oratorios and orchestral music. "Hometown" was composed in 1937. This was a dramatic anti-war song. It expressed the sad feelings of both the composer and the poet. They were both forced to leave their hometown after the war began. ${ }^{59}$

\footnotetext{
${ }^{58}$ Zhang Anzhi, his pen name is Zhang Fan.

${ }^{59}$ Li Wang, Chinese Classical Art Song 1920-1949, Volume One [in Chinese], (Beijing: People's Music Publishing House, 2015), 199.
} 
Composer: Lu Huabai (陆华柏, 1914-1994)

Title: Yong Shi Gu (勇士骨,1938)

Title translation: The Warriors' Bones

Publisher: People's Music

Poet: Hu Ran (胡然 $\left.{ }^{60}, 1911-1990\right)$

Poem style: Modern Chinese poetry

Difficulty level: Advanced level

Voice type: Tenor

Tessitura: C4-A5

Duration: 02:16 mins

Voice characteristics: stepwise melody and skips; parlando-style and aria-like setting; upward leaps of octaves from G4 to G5, and G5 was sustained; most phrases start on the afterbeat; dramatic heroism theme

Piano accompaniment: relatively long prelude; changes of music textures between first and middle sections; quick running arpeggiated notes; blocks of chords in triplets; uses full keyboard; tremolos in the end

Comments: The poet, Hu Ran was a famous Chinese tenor. He met the composer, Lu Huabai, in the city of Guilin (桂林). They collaborated on this song, “The Warriors' Bones." It was an arialike song. The middle section was written in parlando style. It was also a popular anti-war song.

${ }^{60} \mathrm{Hu}$ Ran's pen name is Ying Fen (映茄). 
Composer: Nie Er (聂耳, 1921-1935)

Piano arrangement: Chen Yixin (陈贻蓥, 1926-)

Title: Gao Bie Nan Yang (告别南洋, 1934)

Title translation: Farewell to the South Asia

Publisher: People's Music

Poet: Tian Han (田汉, 1898-1968)

Poem style: Modern Chinese poetry

Difficulty level: Beginning level

Voice type: Tenor, Baritone

Tessitura: E4-E5

Duration: 02:44mins

Voice characteristics: stepwise and small skips; syllabic setting; symmetrical phrases; easy rhythm; limited dynamic range

Piano accompaniment: sustained blocks of chords; arpeggiated passages; tremolos; double the voice part, harmonically supportive

Comments: "Gao Bie Nan Yang” was an episode of Tian Han's drama Return of Spring. The song was about a young Chinese man in Vietnam who decided to go back to China and fight in the war instead of marrying his lover and staying there. The song expressed his passion for the country and desire to end the war. 
Composer: Nie Er (聂耳, 1921-1935)

Piano arrangement: Song Chengxian (宋承宪)

Title: Meiniang Qu (梅娘曲, 1934)

Title translation: Song of Meiniang

Publisher: People's Music

Poet: Tian Han (田汉, 1898-1968)

Poem style: Modern Chinese poetry

Difficulty level: Beginning level

Voice type: Soprano, Mezzo-soprano

Tessitura: D4-E5

Duration: 02:44mins

Voice characteristics: small skips and stepwise; lyrical and gentle; triplets; dotted rhythms; many phrases begin on the afterbeat; syllabic setting

Piano accompaniment: blocked od chords and broken chords; arpeggiated passages; doubles the voice part; slow rhythmic motion

Comments: This song was another episode of Tianhan's drama Return of Spring. The lyrics were written from the perspective of the protagonist, Meiniang. Her lover was injured and lost his memory while participating in the war. Throughout the song, Meiniang articulated a monologue directed to her lover. This monologue described their love story in the past and hoped to evoke her lover's memories. The mood portrayed gentle and sad feeling. 
Composer: Nie Er (聂耳, 1921-1935)

Piano arrangement: Qu Xixian（㫿希贤, 1919-2008)

Title: Tie Ti Xia de Ge Nv (铁蹄下的歌女, 1935)

Title translation: The Singing Women under the Iron Hoof

Publisher: People's Music

Poet: Xu Xing Zhi (许幸之, 1904-1991)

Poem style: Modern Chinese poetry

Difficulty level: Beginning level

Voice type: Soprano, Mezzo-soprano

Tessitura: C4-D5

Duration: 02:34mins

Voice characteristics: small skips and stepwise; ornamented notes; many descending passages; short phrases; syllabic setting; limited dynamic range

Piano accompaniment: arpeggiated patterns; many octaves; harmonically supportive to the voice part; short passages of call and response

Comments: This was originally an episode from the movie Feng Yun Er Nv (Children under the Windy (loud). It was a movie directed by Xu Xingzhi in 1935. It became popular and Qu Xixian arranged the piano accompaniment. Then it became a classical selection in Chinese art song repertoire. It was a sorrowful and dramatic song. This song described the wandering experiences of women who made a living by singing on the street. 
Composer: Ren Guang (任光, 1990-1941)

Piano Arrangement: Cheng Yixin (陈贻金金, 1926-)

Title: Yu Guangqu (渔光曲, 1934)

Title translation: Fisherman's Song

Publisher: People's Music; Shanghai Educational

Poet: An E (安娥, 1905-1976)

Poem style: New-style lyrics

Difficulty level: Beginning level

Voice type: Soprano, Mezzo soprano

Tessitura: D4-A5

Duration: 2:07mins

Voice characteristics: mostly chordal skips; syllabic setting; symmetrical phrases; gentle and lyrical; easy rhythm; limited dynamic range; harmonically supported by piano

Piano accompaniment: linear texture; triplets; arpeggiated passages; blocked chords; doubles the voice part; brief prelude and postlude

Comments: This song was an episode from a movie of the same name. The poet and the composer were a couple. The song became very popular because of the success of the movie. Later, Chen Yixin wrote the piano arrangement for solo voice. The piano version was frequently sung in classical art song recitals. 
Composer: Sha Mei (沙梅, 1909-)

Title: Da Chai Ge (打柴歌, 1930s)

Title translation: Chopping Wood Song

Publisher: Shanghai Educational

Poet: Chen Zizhan (陈子展, 1998-1990)

Poem style: Modern Chinese poetry

Difficulty level: Intermediate level

Voice type: All types

Tessitura: D4-G5

Duration: 02:50 mins

Voice characteristics: small skips and stepwise melody; two-note slurs; folk-song style; lighthearted mood; dotted rhythms; relatively quick rhythmic motion; syllabic and melismatic settings

Piano accompaniment: mostly arpeggiated patterns; blocks of chords and octaves; doubles the voice part; harmonically supportive; quick rhythmic motion; light and gentle

Comments: This was a light-hearted art song. It was composed in the style of the mountain songs, which is a genre of Chinese folk song. In the rural areas near mountains, people usually chopped wood for a living. They often sang mountain songs while working. 
Composer: Wang Luobin (王洛宾, 1913-1996)

Piano Arrangement: Zhang Yan'ni (张彦妮)

Title: Zai Na Yao Yuan de Di Fang (在那遥远的地方, 1939)

Title translation: At That Distant Place

Publisher: People's Music

Poet: Kazakhs Folk Song

Difficulty level: Intermediate level

Voice type: Tenor

Tessitura: F4-G5

Duration: 03:08 mins

Voice characteristics: Flowing and legato; stepwise and small skips; an upward leap in an interval of seventh; syllabic setting; rhythm fairly easy; limited dynamic range; folk-song style

Piano accompaniment: long prelude in solo passages; quick running arpeggiated notes throughout; blocks of chords and octaves; uses full keyboard; harmonically supportive to the voice part

Comments: Wang Luobin, was a famous ethnic composer in China. He collected and arranged more than a thousand folk songs in his lifetime. "Zai Na Yao Yuan de Di Fang" was one of his early works. It described a love story that happened in the Kazakhs area of China. It was a lyrical and expressive song. 
Composer: Xia Zhiqiu (夏之秋, 1912-1993)

Title: Si Xiang Qu (思乡曲, 1939)

Title translation: The Song of Homesickness

Publisher: People's Music

Poet: Dai Tiandao (戴天道, 1904-1991)

Poem style: Modern Chinese poetry

Difficulty level: Intermediate level

Voice type: All types

Tessitura: C4-D5

Duration: 03:34mins

Voice characteristics: stepwise and small skips; many ascending melody lines; sustained and ascending notes on E5-F5-G5 repeatedly; syllabic setting; not for beginners; limited dynamic range

Piano accompaniment: hymn-like accompaniment; doubles the voice part in the beginning; broken chords; blocks of chords; octaves; playing canon with the voice in the middle section

Comments: This song was written to describe his experiences of homesickness. The music employed a calm mood to evoke those feelings. Xia Zhiqiu was a famous trumpet player from the early $20^{\text {th }}$ century. He composed the music in 1938. Then Dai Tiandao wrote the lyrics for the song in 1939. 
Composer: Xian Xing Hai (冼星海, 1905-1945)

Title: Ye Ban Ge Sheng (夜半歌声, 1937)

Title Translation: Singing at Midnight

Publisher: People's Music

Poet: Tian Han (田汉, 1898-1968)

Poem style: New-style lyrics

Difficulty level: Intermediate level

Voice type: Tenor

Tessitura: D4-G5

Duration: 6:30 mins

Voice characteristics: very expressive and lyrical; stepwise and many wide skips; some parlando style passages in the middle section; sustained notes on F5; rhythm fairly easy; wide range of dynamics

Piano accompaniment: use full keyboard; rapid arpeggiated passages in sixteenth notes; repeated tremolos; with blocked chordal patterns; wide range of dynamic control; brief prelude and interlude

Comments: This is the episode of the film Song of the Midnight Night in 1973. It tells the story of a famous theater singer who fell in love with a girl. The girl's father was a local rich businessman. However, they keep dating even though it was opposed by the girl's family. Later, his theater was burned down. Because his face was disfigured after the fire, he hides all the time. Everyone thought he was dead. The girl developed a mental disorder. The only thing that could comfort her was the singing of her lover in the midnight.

This is the midnight song by the singer. It expresses the strong anger and a longing for his missing lover. The poet, Tian Han, wrote the lyrics of the song. He was one of the founders of the modern Chinese drama, and an important scholar in Chinese literature. He also wrote the lyrics of the Chinese National Anthem. ${ }^{61}$

\footnotetext{
${ }^{61}$ Mimi Yang, Jie Zheng, and Liping Zhao, Chinese Art Song Tutorial [in Chinese], (Shanghai Educational Publishing House, 2009), 134.
} 
Composer: Xian Xing Hai (洗星海, 1905-1945)

Piano arrangement: Li Yinghai (黎英海, 1927-2007)

Title: Huang He Song (黄河颂, 1939)

Title Translation: Ode to the Yellow River

Publisher: People's Music

Poet: Guang Weiran (光未然 1913-2002)

Poem style: Modern Chinese poetry

Difficulty level: Intermediate level

Voice type: Baritone, Tenor

Tessitura: D4-G\#5

Duration: 4:15 mins

Voice characteristics: wide leaps and many skips; lyrical and expressive; syllabic and melismatic setting; several sustained notes on E5 and F\#5; ornamented notes for imitating Chinese speaking tune; need good breathing control; for more advanced singers of intermediate level

Piano accompaniment: use full keyboard; repeated tremolos; with blocked chordal patterns; many octaves in either sustained notes or tremolos; wide range of dynamics; brief prelude and interlude; has an independent melody line in the final part

Comments: This is a song that expresses love for the country by praising the beauty of the Yellow River. It not only encapsulates the sight of the beautiful scenery, but also praises the Chinese ethical spirit. Guang Weiran was a modern Chinese poet and literary critic. He wrote the collection of poems entitled Yellow River Cantata. Later, Xian Xinghai used this collection to write the famous oratorio Yellow River Cantata for chorus and orchestra ${ }^{62}$ The "Ode to Yellow River" and two other songs, "Yellow River Ballad", and "Yellow River Resentment" later became the classic selections of Chinese art song repertoire. The piano version mentioned in this study is arranged by Li Yinghai.

\footnotetext{
${ }^{62}$ Mimi Yang, Jie Zheng, and Liping Zhao, Chinese Art Song Tutorial [in Chinese], (Shanghai Educational Publishing House, 2009), 167.
} 
Composer: Xian Xinghai (洗星海, 1905-1945)

Piano arrangement: Liu Zhang (刘庄, 1932-)

Title: Huang Shuiyao (黄水谣, 1939)

Title Translation: Yellow River Ballad

Publisher: People's Music

Poet: Guang Weiran (光未然 1913-2002)

Poem style: Modern Chinese poetry

Difficulty level: Intermediate level

Voice type: Soprano, Mezzo-soprano

Tessitura: B3-G5

Duration: 3:20 mins

Voice characteristics: small skips and small stepwise melodies; lyrical and flowing phrases; dotted rhythm; syllabic setting with several melismatic ones

Piano accompaniment: blocked chords; quick intervals in sixteenth notes; repeated tremolos in both hands; use full keyboard; harmonically supportive to the vocal part

Comments: This is another selection from Yellow River Cantata. The main character is a woman. She describes the war ruining her hometown and breaking up her family. It is written in A-B-A form. The A section praises the beauty of her hometown by employing a calm and graceful mood. The B section developed a contrasted mood by recalling the war and describing the destruction of the peace in her hometown. The return of the A section sends us back to the present moment with grief and sadness. 
Composer: Xian Xinghai (洗星海, 1905-1945)

Piano arrangement: Li Yinghai (黎英海, 1927-2007)

Title: Huang Heyuan (黄河怨, 1939)

Title Translation: Yellow River Resentment

Publisher: People's Music

Poet: Guang Weiran (光未然 1913-2002)

Poem style: Modern Chinese poetry

Difficulty level: Intermediate level

Voice type: Soprano

Tessitura: C4-G5

Duration: 4:55 mins

Voice characteristics: mostly small skips and stepwise melody; many dotted rhythms; syllabic setting; very dramatic; intense mood of anger and grief; several sustained long notes on B5

Piano accompaniment: long prelude; quickly arpeggiated passages; blocked chords and octaves throughout; harmonically supportive to the voice

Comments: This is another song in Yellow River Cantata. It is a storytelling and aria-like song. A woman tells her tragic story of her life affected by the war. There is an intense mood of resentment throughout. 
Composer: Ying Shangneng (应尚能, 1902-1973)

Title: Diao Wusong (吊吴淞, 1933)

Title Translation: Commemorate of the Dead Soldiers at $W u$ Song $^{63}$

Publisher: Shanghai Educational

Poet: Wei Hanzhang (韦瀚章, 1905-1993)

Poem style: Classical Chinese poetry

Difficulty level: Intermediate level

Voice type: Baritone

Tessitura: A3-F5

Duration: 2:30mins

Voice characteristics: small stepwise and small skips; wide leaps in sevenths in the second part; accidentals; syllabic setting; limited dynamic control

Piano accompaniment: quick arpeggiated patterns throughout the song; independent from the vocal part; some difficulties in ensemble

Comments: Although he is a modern poet, Wei Hanzhang wrote this poem in the form of classical Chinese poetry. Ying Shangneng wrote the song to commemorate the soldiers that died in the war in $1932 .{ }^{64}$

${ }^{63} \mathrm{Wu}$ Song is a district of the city of Shanghai in China.

${ }^{64}$ Shaojun Zhang and Yanjing Zhang, A Cultural History of Modern China [in Chinese], (Beijing: Zhonghua Publishing House, 2018). 
Composer: Zhang Hanhui (张寒晖, 1902-1946)

Piano arrangement: Zhang Dong (张栋)

Title: Songhua Jiang Shang (松花江上, 1936)

Title translation: On the Songhua River

Publisher: People's Music

Poet: Zhang Hanhui (张寒晖, 1902-1946)

Poem style: Modern Chinese poetry

Difficulty level: Intermediate level

Voice type: All Type

Tessitura: C4-G5

Duration: 4:08mins

Voice Characteristics: many skips and some wide leaps; lyrical and expressive; long phrases; fairly easy rhythm; meter change $4 / 4$ to $3 / 4$; wide dynamic range; harmonically supported by the piano

Piano accompaniment: tremolos; use full keyboard; blocked of chords; many octaves; triplets in quick rhythmic motion; wide dynamic range

Comments: This is a typical anti-war song. It described the painful experiences of the Chinese people who had to leave their home and escape because of the invasion of Japan in the 1930s. 
Composer: Zhang Xiaohu (张肖虎, 1914-1997)

Title: Sheng Sheng Man: Xun Xun Mi Mi (声声慢・寻寻受受, 1933)

Title translation: Sheng Sheng Man: The Searching

Publisher: Shanghai Educational

Poet: Li Qingzhao (李清照, 1084-1151)

Poem style: classical Chinese poetry

Difficulty level: Intermediate level

Voice type: Soprano, Mezzo-soprano

Tessitura: C\#4-F\#5

Duration: 03:18 mins

Voice characteristics: many skips in small and wide intervals; syllabic setting and some melismatic setting; in Chinese pentatonic mode; calm and gentle mood

Piano accompaniment: broken chord patterns; quick running arpeggiated notes; depicts raining sounds through the use of repeated single notes; doubles the voice part; short interlude; limited dynamic range

Comments: "Sheng Sheng Man" (Sheng Sheng Man: Xun Xun Mi Mi) was a famous poem written by Li Qingzhao, an influential female poet from the Song Dynasty. "Sheng Sheng Man" was a type of lyric title (Cipai) in Lyric (Ci) poetry. "Xun Xun Mi Mi" means "searching" in English. This song was written during the national crisis of the Song Dynasty. At the same time, Li Qingzhao's second marriage was not going very smoothly. She wrote this poem to express her feelings of desolation for both the country and herself. Zhang Xiaohu was an influential Chinese composer and music educator. The song was representative of his works. 
Composer: Zheng Lvcheng (郑律成, 1914-1976)

Piano Arrangement: Tu Ye Jiu (屠冶九, 1927-)

Title: Yan Shui Yao (延水谣, 1938)

Title translation: The Ballade of Yan River

Publisher: People's Music

Poet: Xiong Fu (熊复, 1916-1995)

Poem style: Modern Chinese poetry

Difficulty level: Beginning level

Voice type: Soprano; Mezzo-soprano

Tessitura: E4-E5

Duration: 02:15 mins

Voice characteristics: small skips and stepwise melody; short phrases; gentle and lyrical; syllabic setting; easy rhythm; limited dynamics

Piano accompaniment: Arpeggiated patterns throughout; call and response passages; harmonically supportive to the voice; limited dynamic range

Comments: This was a very popular anti-war song. It was composed at the city of Yan'an in 1938. 
Composer: Zhou Shu'an (周淑安, 1894-1974)

Title: Yu (雨, 1932)

Title Translation: Rain

Publisher: People's Music; China Youth

Poet: Anonymous (件名)

Poem style: Modern Chinese poetry

Difficulty level: Beginning level

Voice type: All voice types

Tessitura: D4-G5

Duration: 1:30 mins

Voice characteristics: stepwise and small skips; short phrases; syllabic setting; easy rhythm; easy word projections; limited dynamic range; very good selection for beginner level

Piano accompaniment: repetition on single notes in sixteenths; imitates raining sound; prelude and interlude; harmonically supportive to the voice part; linear texture; some accidentals

Comments: It was a simple song with a quiet and calm mood. Zhou Shu'an composed it for the children's song book. ${ }^{65}$ The lyrics showed children's curiosity and innocence.

${ }^{65}$ Li Wang, Chinese Classical Art Song 1920-1949, Volume One [in Chinese], (Beijing: People's Music Publishing House, 2015),28. 


\section{Chapter V: Annotated Listing of Chinese Art Songs in the 1940s}

Composer: Chen Tianhe (陈田鹤, 1911-1955)

Title: Jiang Cheng Zi (江城子, 1944)

Title translation: Jiang Cheng $\mathrm{Zi}$

Publisher: Shanghai Educational

Poet: Qin Guan (秦观, 1049 -1100)

Poem style: Classical Chinese poetry

Difficulty level: Intermediate level

Voice type: All voice types

Tessitura: Bb3-Eb5

Duration: 1:55 mins

Voice characteristics: Flowing and legato phrases; syllabic setting; some accidentals; limited dynamic range; calm and gentle mood

Piano accompaniment: arpeggiated patterns in triplets; doubles the voice line; short interlude and prelude; some blocked chords; linear texture

Comments: Qin Guan was an important literature scholar and politician in the Song dynasty. He was a prolific poet and writer. His political career was not successful. ${ }^{66}$ "Jiang Cheng Zi" was considered one of his typical poems. The poem expressed his discontentment that his youth had passed him by. It also described his sadness over parting with his lover. In the context of war, Chen Tianhe composed the song based on his own experience away from home. He set the poem to the song "Jiang Chen Zi" in 1944. The mood of this song was calm with a touch of sadness. The melody was written with consideration of speech pattern and rhythm; employing a chantinglike style.

${ }^{66}$ Chunxiang Lin, “Poetic Style of Qin Guan under Competition between New and Old Partisans” [in Chinese], Journal of Longyan University 33, no. 1 (February 2015): 117. 
Composer: Fan Jisen (范继森, 1917-1969)

Title: An Shui Ba, Yong Shi (安眠吧, 勇士, 1943)

Title translation: Rest in Pease, Warriors

Publisher: People's Music

Poet: Tian Han (田汉, 1898-1968)

Poem style: Modern Chinese poetry

Difficulty level: Intermediate level

Voice type: Tenor, Soprano

Tessitura: C\#4-A5

Duration: 4:10mins

Voice characteristics: intense mood of grieving; many upward leaps in octaves; sustained notes on G5; starting phrases on A5; many dotted rhythms; some accidentals; parlando style passages; mostly syllabic setting

Piano accompaniment: uses full keyboard; many passages of quick running notes; blocked chords in dotted rhythm; arpeggiated patterns in triplets; solo passages; long interlude and prelude; independent role from the voice part; harmonically supportive to the voice

Comments: Fan Jisen was a famous pianist and composer in the $20^{\text {th }}$ century. He was an influential educator in Piano Performance. Tian Han wrote the poem "Zhan Shi Ai Ge" (Warriors' Lament) in 1937. Then Fan Jisen set the poem to the song and changed its name to "An Shui Ba, Yong Shi” (Rest in Peace, Warriors) in 1943. ${ }^{67}$

${ }^{67}$ Li Wang, Chinese Classical Art Song 1920-1949, Volume One [in Chinese], (Beijing: People's Music Publishing House, 2015), 232. 
Composer: Huang Yongxi (黄永熙, 1917-2003)

Title: Huai Nian Qu (怀念曲, 1940s)

Title translation: The Yearning Song

Publisher: People's Music

Poet: Mao Yu (毛羽, )

Poem style: Modern Chinese poetry

Difficulty level: Intermediate level

Voice type: All types

Tessitura: C\#4-F\#5

Duration: 4:53 mins

Voice characteristics: flowing and lyrical phrases; small skips and stepwise melody; sustained notes at the end of each phrase; syllabic settings; tempo marked as "Lento"; limited dynamic range; need good breathing control

Piano accompaniment: arpeggiated patterns throughout in the first section; broken chord patterns, mostly in the second section; prelude and interlude; harmonically supportive to the voice part

Comments: Huang Yongxi was a Chinese conductor and composer. He wrote many works of sacred music and Chinses art songs. "The Yearning Song" was written in the 1940s. The song expressed the singer's deep longing for their lover during a time of separation. 
Composer: Huang Youdi (黄友棣, 1911-2010)

Title: Du Juan Hua (杜鹃花, 1941)

Title translation: The Rhododendron

Publisher: People's Music

Poet: Wu Jun (芜军, 1898-1968)

Poem style: Modern Chinese poetry

Difficulty level: Beginning level

Voice type: All types

Tessitura: C4-F5

Duration: 3:16 mins

Voice characteristics: stepwise melody and some wide skips; upward leaps in intervals of sixths; dotted rhythms; some accidentals; sustained notes on F5; syllabic setting with some melismatic passages

Piano accompaniment: wide span of blocked chords; sustained octaves in the left hand; harmonically supportive to the voice; limited dynamic range; simple rhythm

Comments: Huang Youdi was a composer and music educator in China. He wrote many vocal works including sacred choral music, art songs, and children's songs. "Du Juan Hua" was representative of his art songs. ${ }^{68}$ Because it was set in a quick tempo, it sounded like a lighthearted song. By reading between the lines, it became clear that the song described the story of a lost lover in the war. The lyrics gave hints of this tragic story. For example, the lyrics referenced the red color of the Rhododendron and the gunfire from the war to symbolize the death of the lost lover.

${ }^{68}$ Mingyi Fei, "In memory of professor Huang Youdi" [in Chinese], Yueyou/Music Companion, no. 93 (December 2010): 2-4. 
Composer: Jin Sha (金眇, 1922-1996)

Piano arrangement: Li Xi’an (李西安, 1937-)

Title: Mu Yang Gu Niang (牧羊姑娘, 1941)

Title translation: The Shepherd Girl

Publisher: People's Music;

Poet: Di Fan (荻帆, 1917-1995)

Poem style: Modern Chinese poetry

Difficulty level: Beginning level

Voice type: Soprano, Tenor

Tessitura: F4-A5

Duration: 3:25 mins

Voice characteristics: small skips and stepwise melody; syllabic setting; folk-song style; limited dynamic range; simple rhythmic structure; strophic form

Piano accompaniment: quick arpeggios and sustained chords throughout the song; doubles the voice part; limited dynamic range; short prelude, interlude, and postlude

Comments: Jin Sha, original name was Liu Ruiming, who was a Chinese composer from the 20th century. The art song, "Shepherd Girl," belonged to his early works. ${ }^{69}$ It was very popular during that time. Li Xi'an arranged it with piano accompaniment. Later it became a classic selection in Chinese art song repertoire.

${ }^{69}$ Xianjun Luo, Normal College Education Teaching Source: Selected Vocal Works: Chinese Works I [in Chinese], (Beijing: People's Music Publishing House, 2013). 
Piano arrangement: Jiang Dingxian (江定仙, 1922-1996)

Title: Kang Ding Qing Ge (康定情歌, 1940s)

Title translation: Kongding Love Song

Publisher: People's Music;

Poet: Sichuan Folk Song

Poem style: Sichuan (Tibetan) Folk Song

Difficulty level: Beginning level

Voice type: All types

Tessitura: D4-D5

Duration: 2:16 mins

Voice characteristics: small skips and stepwise melody; syllabic setting; limited dynamic range; simple rhythmic structure; strophic form; folk-song style; very good selection for beginners

Piano accompaniment: short prelude, interlude, and postlude; doubles the voice part; blocked chords in a range of octaves; plays canon with the voice part in the final section; independent voice line; harmonically supportive to the voice

Comments: "Kangding Love Song" was originally written under the name of "A Running Horse on the Hill." In the 1940s, this song was arranged by Jiangding Xian according to "Liuliu Tune," a Sichuan folk song. "Liuliu tune" was a popular type of folksong in the southwest region of China. $^{70}$

${ }^{70}$ Xianjun Luo, Normal College Education Teaching Source: Selected Vocal Works: Chinese Works I [in Chinese], (Beijing: People's Music Publishing House, 2013), 233. 
Composer: Lin Shengxi (林声翕, 1914-1991)

Title: Shui Diao Ge Tou: Ming Yue Ji Shi You (水调歌头・明月几时有, 1942)

Title translation: The Prelude of the Water Tune: How Long Until the Full Moon Appears?

Publisher: Shanghai's Educational

Poet: Su Shi (苏轼, 1037-1101)

Poem style: Classical Chinese poetry

Difficulty level: Intermediate level

Voice type: All types

Tessitura: D4-D5

Duration: 2:16 mins

Voice characteristics: Flowing and sweeping melody; wide leaps in intervals of sixths and octaves; sustained notes on F5; syllabic setting; meter changes from 6/4, 4/4, 12/8 and back to $6 / 4$

Piano accompaniment: broken chords; octaves; arpeggiated passages in triplets; texture changes between different sections; tremolos; quick running sixteenth notes in scale passages; harmonically supportive to the voice part

Comments: "Shui Diao Ge Tou: Ming Yue Ji Shi You" was a famous poem written by poetry master Su Shi from the Song dynasty. ${ }^{71}$ Su Shi expressed his desire to reunite with his family. He expressed this longing through the metaphor of the full moon. He compared the moon cycle to the cycle of reuniting and separating with family.

\footnotetext{
${ }^{71}$ Li Wang, Chinese Classical Art Song 1920-1949, Volume One [in Chinese], (Beijing: People's Music Publishing House, 2015),197.
} 
Composer: Liu Xue'an (刘雪庵, 1905-1985)

Piano arrangement: Sang Tong (桑桐, 1923-2011)

Title: Hong Dou Ci (红豆词, 1943)

Title translation: The Poem of the Red Beans

Publisher: People's Music

Poet: Cao Xueqin (曹雪芹, 1715-1763)

Poem style: New-style lyrics

Difficulty level: Beginning level

Voice type: Soprano, Tenor

Tessitura: Db4-Ab5

Duration: 2:49 mins

Voice characteristics: Flowing and sweeping melody; few wide leaps in interval of sixths and sevenths; syllabic setting; easy rhythm; limited dynamic range

Piano accompaniment: blocks of chords in a range of octaves; syncopated rhythms; broken chords; three-voice texture; short prelude; call and response passages; harmonically supportive to the voice part

Comments: The poem, "Hong Dou Ci" was selected from Dream of the Red Chamber by Cao Xueqin. Dream of the Red Chamber belonged to one of China's Four Great Classical Novels. "Hong Dou Ci" was chanted and sung by Jia Baoyu, who expressed longing and anxiety for his lover. "Hong Dou" can be translated as red bean in English. It was a typical metaphor for lovesickness in Chinese literature. 
Composer: $\mathrm{Ma} \operatorname{Ke}$ (马克, 1918-1976)

Title: Nan Ni Wan (南泥湾, 1943)

Title translation: The Nanni Bay

Publisher: People's Music

Poet: He Jingzhi (贺敬之, 1924-)

Poem style: Modern Chinese poetry

Difficulty level: Intermediate level

Voice type: Soprano.

Tessitura: Eb4-Ab5

Duration: 2:28 mins

Voice characteristics: stepwise melody and small skips; folk-song style; strophic form; syllabic setting; easy rhythm; limited dynamic range; light-hearted mood

Piano accompaniment: short prelude and interlude; arpeggiated patterns; broken chord patterns; fairly quick rhythmic mode; harmonically supportive to the voice

Comments: "Nan Ni Wan" was originally an episode from the folk dance Yao Hua Lan. Ma Ke composed the song and it was very popular during the early 20th century. Later, it became a classic selection of Chinese art song repertoire. ${ }^{72}$ It was a light-hearted and happy song. This song expressed praise for the scenery and working people in the area of the Nanni Bay.

\footnotetext{
72 Xianjun Luo, Normal College Education Teaching Source: Selected Vocal Works: Chinese Works I [in Chinese], (Beijing: People's Music Publishing House, 2013), 180.
} 
Composer: Ma Sicong (马思聪, 1912-1987)

Title: Hai Shang (海上, 1943)

Title translation: On the Sea

Publisher: People's Music

Poet: Guo Moruo (郭沫若, 1892-1978)

Poem style: Modern Chinese poetry

Difficulty level: Advanced level

Voice type: All types

Tessitura: C4-G5

Duration: 3:12 mins

Voice characteristics: angular motion; wide leaps in intervals of sixths and sevenths; flowing and lyrical; many accidentals; ternary form; dreamy and floaty feeling

Piano accompaniment: short prelude, interlude, and postlude; broken chords in wide ranges that imitate the rocking boats; quick arpeggios in repeated patterns; contrasting textures between A and B sections

Comments: "Hai Shang" was selected from song cycle After the Rain by Ma Sicong. It was representative of Ma Sicong's vocal compositions. There were six songs in the song cycle: After the Rain, The Sphinx Under the Moon, The Rain Stops, The Wedding during the Sunset, On the Sea, and Hai Shang. "Hai Shang" was the last song. By portraying the image of rocking boats on the sea, it expressed the feeling of uncertainty and sadness while leaving one's hometown. Guo Moruo was one of the founders of modern Chinese poetry. He was an influential figure in both Chinese Literature and History. Ma Sicong was a famous Chinese composer and violinist. His musical works included violin solos, art songs, operas, and orchestra music. 
Composer: Tan Xiaolin (谭小麟, 1912-1948)

Title: Bie Li (别离, 1946)

Title translation: Saying Goodbye

Publisher: Shanghai's Education

Poet: Guo Moruo (郭沫若, 1892-1978)

Poem style: Classical Chinese poetry

Difficulty level: Intermediate level

Voice type: Tenor or Baritone

Tessitura: D4-G5

Duration: 1:43 mins

Voice characteristics: flowing and sweeping melody; many skips and wide leaps; mostly syllabic setting with few melismatic settings; accidentals; specified descriptions of dynamics and expression

Piano accompaniment: broken chord patterns; three-voice texture; many accidentals; triplets; independent melody line; slow-rhythmic motion

Comments: "Saying Goodbye" was a typical art song composed by Tan Xiaolin. Tan studied in the Oberlin Conservatory and Yale university with Paul Hindemith, who influenced his use of non-diatonic composition. When he came back to China in the late 1940s, he applied Hindemith's composition method with Chinese music style. He composed many art songs as teaching examples for his composition students. ${ }^{73}$

\footnotetext{
${ }^{73}$ Suxian Yu, "Contemporary techniques in Tan Xiaolin's compositions" [in Chinese], Yinyue Yanjiu/Music Research 58, no. 3 (January 1990): 53-61.
} 
Composer: Tan Xiaolin (谭小麟, 1912-1948)

Title: Zheng Qi Ge (正气歌, 1947)

Title translation: The Song of Righteousness

Publisher: Shanghai's Education

Poet: Wen Tianxiang (文天祥, 1236-1283)

Poem style: Classical Chinese poetry

Difficulty level: Intermediate level

Voice type: Tenor

Tessitura: D4-A5

Duration: 1:40 mins

Voice characteristics: stepwise melody with wide leaps in intervals of sixths and sevenths; syllabic and melismatic settings; sustained and accented notes on G5; meter and tempo changes; heroism theme

Piano accompaniment: blocks of chord in octave ranges; 3-voice texture; contrapuntal writing; triplets; short prelude; independent melody line; harmonically supportive to the voice; ensemble is difficult because the piano plays in triplets while the voice simultaneously sings in duplets

Comments: "Zheng Qi Ge” was a vocal work that was representative of Tan Xiaolin's works. It was written in 1946. It was based on the patriotic poem written by Wen Tianxiang from the Song dynasty. Wen wrote the poem while he was imprisoned by the enemy. He stated that he would rather die than surrender. So, he wrote this poem to show loyalty to his country. ${ }^{74}$

\footnotetext{
${ }^{74}$ Zhang Wei, "Discussion of the style characteristics and performance of Tan Xiaolin's art songs: On the examples of Penglang ji and Zhengqi ge" [in Chinese], Journal of Nanjin Arts Institute 128, no. 2 (Summer): 123-128.
} 
Composer: Tan Xiaolin (谭小麟, 1912-1948)

Title: Zi Jun Zhi Chu Yi (自君之出矣, 1945)

Title translation: Since the Day of Your Departure

Publisher: Shanghai's Educational

Poet: Zhang Jiuling (张九龄, 678-740)

Poem style: Classical Chinese poetry

Difficulty level: Intermediate level

Voice type: Soprano, mezzo-soprano

Tessitura: C4-E5

Duration: 00:45 mins

Voice characteristics: angular motion; melismatic setting; most phrases start on the afterbeats; frequent dynamic changes in each phrase; many dotted rhythms to imitate speech

Piano accompaniment: broken chords; linear texture; octaves; harmonically supportive to the voice part; slow rhythmic motion; wide dynamic range in a short song

Comments: "Zi Jun Zhi Chu Yi" was written by Zhang Jiuling, a politician and poet in the Tang Dynasty. This poem was a typical five-character quatrain written in the Tang-poetry style. By using the moon as a metaphor, Zhang implicitly expressed a wife's longing for her traveling husband. Tan Xiaolin wrote an English version of the lyrics for this song. He also composed an alternative version of the melody which altered specific pitches throughout in order to better match English intonations. 
Composer: Tan Xiaolin (谭小麟, 1912-1948)

Title: Peng Lang Ji (彭浪矶, 1944)

Title translation: The Penglang Rock

Publisher: Shanghai's Educational

Poet: Zhu Dunru (朱敦儒, 1081 - 1159)

Poem style: Classical Chinese poetry

Difficulty level: Intermediate level

Voice type: Tenor, Baritone

Tessitura: C4-G5

Duration: 02:02 mins

Voice characteristics: stepwise melody; several wide leaps in intervals of sixths and sevenths; syllabic and melismatic setting; parlando style passages; a sustained note on $\mathrm{G}$ in the last phrase; frequent changes of meters between $3 / 4$ and $4 / 4$; limited dynamic range

Piano accompaniment: three-voice texture; contrapuntal writing; sustained bass notes throughout; frequent change of meters; independent melody lines; harmonically supportive to the voice; call and response passages; slow-rhythmic motion

Comments: Zhu Dunru wrote "Peng Lang Ji" when he lost his hometown and country. He was escaping to the southern region of China. He traveled by the Penglang Rock during Autumn. The depressed autumn landscape evoked his feelings of anxiety and sadness. Most of Tan Xiaolin's art songs were based on classical Chinese poetry. Xiaolin combined the Chinese pentatonic mode with Hindemith's compositional style for the first time. Usually Hindemith's work did not indicate key signature in the score. However, Tan used two flats to indicate the usage of Chinese pentatonic mode on $\mathrm{D} .{ }^{75}$

\footnotetext{
${ }^{75}$ Suxian Yu, "Contemporary techniques in Tan Xiaolin's compositions" [in Chinese], Yinyue Yanjiu/Music Research 58, no. 3 (January 1990): 53-61.
} 
Composer: Xian Xinghai (洗星海, 1905-1945)

Title: Yi Qin'e: Xiao Shengyan (忆奏娥・箫声咽, 1940)

Title translation: Memories of Qin'e: Weeping Flute

Publisher: People's Music

Poet: Li Bai (李白, 701 - 762)

Poem style: Classical Chinese poetry

Difficulty level: Intermediate level

Voice type: Soprano, Mezzo-soprano

Tessitura: D4-A5

Duration: 04:08 mins

Voice characteristics: flowing and long phrases; stepwise melody with small skips; many sustained notes; melismatic setting; many ornamented passages; G5 and A5 appeared as passing notes; contrasted dynamics in each section

Flute Characteristics: very long prelude with piano and a postlude; has an independent melody line; call and response passage with the voice part; quick running arpeggios in sixteenth notes; long phrases; considerable sustained notes; wide leaps in octaves; long trills; wide dynamic range

Piano accompaniment: very long prelude with the flute and a postlude; mostly arpeggiated passages; broken and blocked patterns of chords; wide dynamic range; three-voice texture; has an independent melody line; harmonically supportive to both the flute and the voice

Comments: Li Bai was a great poetry master in the Tang Dynasty. He wrote more than one thousand poems during his lifetime. People honored him as the "Poet Saint". Xi' an was the city where Li Bai lived and wrote the poem "Yi Qin'e: Xiao Sheng Yan.” Xian Xinghai was staying at the same city in 1940. He had to separate from his family because the war was happening in China. Xian Xinghai deeply resonated with Li Bai's feelings of depression and sadness. In the summer of 1940, Xian Xinghai wrote "Yi Qin'e" for piano, flute, and voice. The song was based on Li Bai's poem. ${ }^{76}$

\footnotetext{
${ }^{76}$ Mimi Liu, "Analysis of Xian Xinghai's Art Song Yi Qin'e" [in Chinese], Journal of Xinghai Conservatory of Music 124, no. 3 (November 2011): 80-85.
} 
Composer: Ying Shangneng (应尚能, 1902-1973)

Title: Wo Nong Ci (我侬词, 1940)

Title translation: The poem of You and I

Publisher: People's Music

Poet: Guan Daosheng (管道升, 1262-1339)

Poem style: Classical Chinese poetry

Difficulty level: Intermediate level

Voice type: Soprano, Mezzo-soprano

Tessitura: Eb4-G5

Duration: 02:50 mins

Voice characteristics: small skips in intervals of thirds and fifths; wide leaps in intervals of sixths; melismatic setting; some accidentals; many ornamented notes; sustained notes on G5; limited dynamic control

Piano accompaniment: blocked patterns of chords throughout; arpeggiated patterns in the left hand; sustained octaves; interlude and short postlude; harmonically supportive to the voice

Comments: Guan Daosheng was a female poet and painter in the Song Dynasty. She wrote this poem to her husband. She expressed her fidelity towards their love by intervening in her husband's attempt to bring home a concubine. After reading this poem, her husband decided to give up on having a concubine. ${ }^{77}$ Ying Shangneng was a baritone singer and composer in the $20^{\text {th }}$ century. He composed many art songs and choral music. He was an influential vocal educator. He was the pioneer who brought the Bel Canto singing method to China. ${ }^{78}$

\footnotetext{
77 Li Wang, Chinese Classical Art Song 1920-1949, Volume One [in Chinese], (Beijing: People's Music Publishing House, 2015), 37.

78 Yuzi Yu, "Artist Ying Shangneng and His Contribution" [in Chinese], Journal of the Central Conservatory of Music 39, no. 2 (January 1990): 67-71.
} 
Composer: Ying Shangneng (应尚能, 1902-1973)

Title: Yu Fu (渔夫, 1942)

Title translation: Old Fisherman

Publisher: People's Music

Poet: Guan Daosheng (管道升, 1262-1339)

Poem style: Classical Chinese poetry

Difficulty level: Intermediate level

Voice type: All types

Tessitura: Bb3-G5

Duration: 02:20 mins

Voice characteristics: angular motion; syllabic and melismatic settings; many skips and wide leaps; ornamented notes; strophic form; limited dynamic range

Piano accompaniment: prelude and interlude; blocks of chords in repeated patterns; sustained octaves; simple texture; harmonically supportive to the voice part

Comments: Su Shi wrote this collection of poems after he was demoted from political power. There were four poems in this collection. The poems expressed his enjoyment of being a simple fisherman and staying outside the trouble of the political conflicts. Ying Shangneng took three poems out of the original four and wrote "Old Fisherman" based on them. He composed this song in 1942. 
Composer: Zhang Shu (张曙, 1908-1938)

Title: Ri Luo Xi Shan (日落西山, 1935)

Title translation: Sunset of the West Mountain

Publisher: People's Music

Poet: Tian Han (田汉, 1898-1968)

Poem style: Modern Chinese poetry

Difficulty level: Beginning level

Voice type: All types

Tessitura: D4-E5

Duration: 01:12 mins

Voice characteristics: small skips and stepwise melody; syllabic setting; syncopations; dotted rhythms; ornamented notes; limited dynamic range

Piano accompaniment: short prelude; broken patterns of chords; doubles the voice part; linear texture; arpeggios in the end

Comments: Zhang Shu's original name was Zhang Enxi. He was a dedicated composer of antiwar songs in the 1930s. During his short lifetime, he composed more than two hundred songs. He valued the use of ethnic style in compositions of modern Chinese art songs. He also wrote his songs in a style that was intentionally accessible for the people at the grass roots. Many of them were easy to sing and understand. The songs mostly described anti-war themes and patriotic feelings. "Ri Luo Xi Shan" was representative of his works during the 1930s. ${ }^{79}$

\footnotetext{
${ }^{79}$ Shen Sun, "Commemorating the $100^{\text {th }}$ years of the death of Zhang Shu" [in Chinese], Renmin yinyue/People's music, no. 9 (September 2008): 56.
} 


\section{Bibliography}

$\underline{\text { Books }}$

Luo, Xianjun. Normal College Education Teaching Source: Selected Vocal Works: Chinese Works I. [In Chinese]. Beijing: People's Music Publishing House, 2013.

Mo, Jigang. Chinese Art Song Performance Guide. [In Chinese]. Shanghai: Shanghai Music Publishing House, 2003.

Sun, YueMei, and Chang Liu. The Appreciation of Chinese Art Songs. [In Chinese]. Hefei: Anhui Art Publishing House, 2015.

Wang, Li. Chinese Classical Art Song 1920-1949, Volume One. [In Chinese]. Beijing: People's Music Publishing House, 2015.

Wang, Yuhe. The History of Modern Chinese Music. [In Chinese]. Beijing: People's Music Publishing House, 2009.

Zheng, Jie, Liping Zhao, and Mimi Yang. Guide of Chinese Art Songs. [In Chinese]. Shanghai: Shanghai Education Publishing House, 2009.

Zhang, Shaojun, and Yanjing Zhang. A Cultural History of Modern China. [In Chinese]. Beijing: Zhonghua Publishing House, 2018.

Zhang, Xiaonong. History of Chinese Vocal Music. [In Chinese]. Shanghai: Shanghai Music Publishing House, 2015.

\section{$\underline{\text { Dissertations }}$}

Chao, Nancy Hao-Ming. "Twentieth Century Chinese Vocal Music with Particular Reference to Its Development and Nationalistic Characteristics from the May Fourth Movement (1919) to 1945." PhD diss., University of California, Los Angeles, 1995. ProQuest (AAT 9526456).

Chi, MeiFeng Kang. "A Performance Guide for Contemporary Chinese Art Songs from Taiwan.” EdD diss., Teachers College, Columbia University,1996. ProQuest (AAT 9635963).

Hallis, Xiang Chen. "Chinese Art Song from 1912-1949." DA diss., The University of Texas at Austin,1995. ProQuest (AAT 9617398).

Tyan, Jann-Ay. "A Performer's Guide to Selected Chinese Art Songs by Twentieth-Century Chinese Composers.” DA diss., The Southern Baptist Theological Seminary, 2003. ProQuest (AAT 3128850). 
Yang, Schuman Chuo. "20th Century Chinese Solo Songs: A Historical and Analytical Study of Selected Chinese Solo Songs Composed and Arranged by Chinese Composers.” PhD diss., George Peabody College for Teachers, Vanderbilt University, 1973.

\section{$\underline{\text { Articles }}$}

Dai, Min. "Musical Thinking of the Common People During the May Fourth Period." [In Chinese]. Journal of Xinghai Conservatory of Music 118, no. 1 (March 2010): 57-58.

Fei, Mingyi. "In Memory of Professor Huang Youdi." [In Chinese]. Yueyou/Music Companion, no. 93 (December 2010): 2-4.

Li, Yan. "Development of Modern Art Song in China." [In Chinese]. Chinese Music 3, no. 1 (January 1990): 36.

Lin, Chunxiang. "Poetic Style of Qin Guan under Competition between New and Old Partisans." [In Chinese], Journal of Longyan University 33, no. 1 (February 2015): 117.

Lu, Zaiyi. "My Opinions on the Composing of Chinese Art Song." [In Chinese]. People's Music 515, no. 8 (August 2007): 8.

Qian, RenKang. "Analysis of Songs Composed by Zhao Yuanren.” [In Chinese]. Musicology in China no.1, (January 1988): 7-8.

Sun, Shen. "Commemorating the 100th Years of the Death of Zhang Shu." [In Chinese]. Renmin Yinyue/People's music, no. 9 (September 2008): 56.

Wang, Yuhe. "Dreams of May 4th: Written in Commemoration of the 90th Anniversary of the May Fourth Movement." [In Chinese]. Huangzhong/ Journal of Wuhan Conservatory of Music 90, no. 2 (Summer 2009): 7.

Wang, Yuhe. "New music of China: Its Development under the Blending of Chinese and Western Cultures through the First Half of the 20th Century. II" [In Chinese]. Journal of the Central Conservatory of Music 60, no. 3, (January 1995):77-78.

Wei, Zhang. "Discussion of the Style Characteristics and Performance of Tan Xiaolin's Art Songs: On the Examples of Penglang Ji and Zhengqi Ge." [In Chinese]. Journal of Nanjin Arts Institute 128, no. 2 (Summer 2011): 123-128.

Xia, Xiaoyan. "The History of Chinese Art Songs in the First Half of the 20th Century." [In Chinese]. Sounds of Nature/Journal of Tianjin Conservatory of Music 78, no. 3 (January 2004): 85.

Xue, Qianghua. "On the Development of Chinese Art Song.” [In Chinese]. Music \& performance/ Journal of Nanjing Arts Institute 99, no. 1 (January 2004):87-89. 
Yang, Lingling. "The Compositional Pattern and Aesthetic Format of Chinese Art Songs." [In Chinese]. Journal of Xi' an Conservatory of Music 142, no. 4 (December 2013): 126-127.

Yu, Suxian. "Contemporary Techniques in Tan Xiaolin's Compositions." [In Chinese]. Yinyue Yanjiu/Music Research 58, no. 3 (January 1990): 53-61.

Yu, Yuzi. "Artist Ying Shangneng and His Contribution." [In Chinese]. Journal of the Central Conservatory of Music 39, no. 2 (January 1990): 67-71.

Zhang, Shaotong. "The Chinese Art Song and Chinese Culture." [In Chinese]. People's Music 521, no. 11 (November 2007): 24-25.

Zeng, Jinshou. "Review of the Origin and Development of Art Song in China (1920-1949)." [In Chinese]. Pts. 1, 2 and 3. Journal of Xi' an Conservatory of Music 60, no. 2 (Summer 1993): 71-72; 61, no. 3 (Fall 1993): 72-74; 62, no. 4 (Winter 1993): 56-57.

\section{$\underline{\text { Website }}$}

"Qu Yuan." Accessed October 14, 2019. Britannica Academic. https://academic-ebcom.www.libproxy.wvu.edu/levels/collegiate/article/Qu-Yuan/82499. 


\section{Appendix I: Lyrics and Translations for Chinese Art Songs from the 1920s}

Composer: Chen Xiaokong (陈啸空, 1904-1953)

Piano arrangement: Zeng Lizhong (曾理中, 1926-1992)

Title: Xiang Lei (湘累, 1924)

Title Translation: Xiang's Weary

Poet: Guo Moruo (郭沫若, 1892-1978)

\begin{tabular}{|c|c|c|}
\hline 湘累 & Xiang's Weary & Xiāng Léi \\
\hline $\begin{array}{l}\text { 我们为了他泪珠儿要流尽 } \\
\text { 了, } \\
\text { 我们为了他, 寸心儿要破碎 } \\
\text { 了, } \\
\text { 爱人呀!还不回来呀? } \\
\text { 层层绕着的九嶷山上的白云 } \\
\text { 呀, } \\
\text { 微微波着的洞庭湖中的流水 } \\
\text { 呀, } \\
\text { 你们知不知道他, 知不知道 } \\
\text { 他的所在呀? } \\
\text { 九嶷山上的白云有聚有消, } \\
\text { 洞庭湖中的流水有汐有潮, } \\
\text { 我们心中的愁云呀! } \\
\text { 我们眼中的泪涛呀! } \\
\text { 永远不能消, 永远只是潮。 } \\
\text { 太阳照着洞庭波, } \\
\text { 我们魂儿颤栗不敢歌, } \\
\text { 待到日西斜, }\end{array}$ & $\begin{array}{l}\text { Our tears are about to run dry, } \\
\text { Lover! You're still not coming back! } \\
\text { We have waited for you from Spring } \\
\text { to Autumn, from Autumn to Summer, } \\
\text { We have waited for you until the sea } \\
\text { has withered and the stone has rotted, } \\
\text { Lover! You're still not coming back! } \\
\text { We have dried out our tears for him, } \\
\text { We have broken our hearts for him, } \\
\text { Lover! Are you coming back? } \\
\text { The white clouds over the Nine-Gating } \\
\text { Mountain, } \\
\text { the water of the Dongting Lake, } \\
\text { Do you know him, do you know where } \\
\text { he is? } \\
\text { The clouds of Nine-Gating Mountain } \\
\text { come and go, } \\
\text { and the waters of Dongting Lake rise } \\
\text { and fall. } \\
\text { The sadness in our hearts! } \\
\text { Tears in our eyes! } \\
\text { Never will decrease, } \\
\text { They are always just a tide. } \\
\text { The sun shines on the lake, } \\
\text { Our souls are in fear and are afraid to } \\
\text { sing, } \\
\text { During the sunset, the flowers of our } \\
\text { tears bloomed. }\end{array}$ & 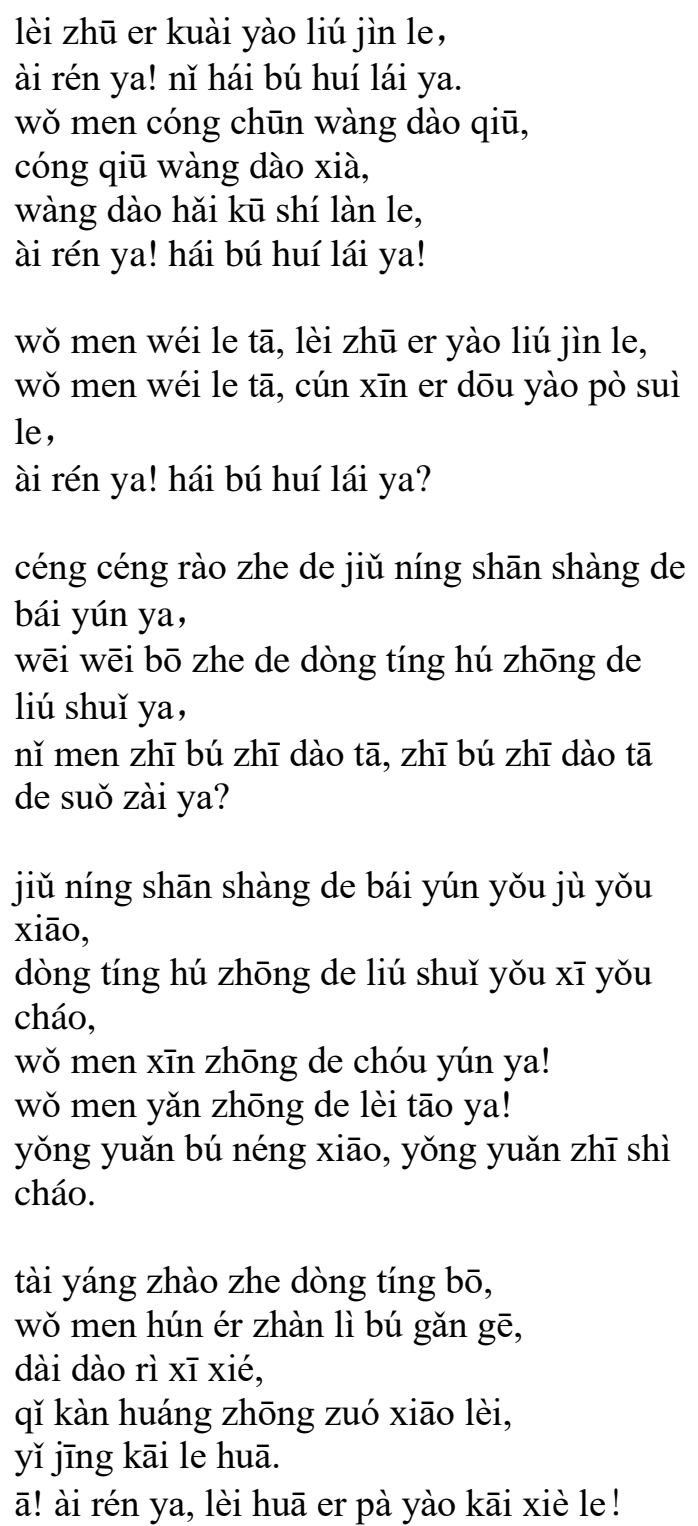 \\
\hline
\end{tabular}




\begin{tabular}{|c|c|c|}
\hline $\begin{array}{l}\text { 起看簣中昨宵泪, } \\
\text { 已经开了花。 } \\
\text { 啊!爱人呀, 泪花儿怕要开谢 } \\
\text { 了! } \\
\text { 你还回不回来呀? }\end{array}$ & $\begin{array}{l}\text { Ah! Lover, the flowers of our tears are } \\
\text { about to wither away! } \\
\text { You, are you coming back? }\end{array}$ & Nĩ hái bú huí lái ya? \\
\hline
\end{tabular}


Composer: Qing Zhu (青主, 1893-1959)

Title: Da Jiang Dong Qu (大江东去, 1920)

Title translation: The River Flowing to the East

Poet: Su Shi (苏轱, 1037-1101)

\begin{tabular}{|c|c|c|}
\hline 大江东去 & The River Flowing to the East & Dà Jiāng Dōng Qù \\
\hline $\begin{array}{l}\text { 大江东去, 浪淘尽, } \\
\text { 千古风流人物。 } \\
\text { 故垒西边, 人道是: 三国周郎赤 } \\
\text { 壁。 } \\
\text { 乱石崩云, 惊涛裂岸, } \\
\text { 卷起千堆雪。 } \\
\text { 江山如画, } \\
\text { 一时多少豪杰。 } \\
\text { 遥想公瑾当年, 小乔初嫁, 雄姿 } \\
\text { 英发。 } \\
\text { 羽扇纶市, 谈笑间、强虏灰飞 } \\
\text { 烟灭。 } \\
\text { 故国神游, 多情应笑我, 早生华 } \\
\text { 发。 } \\
\text { 人间如梦, 一尊还酹江月。 }\end{array}$ & $\begin{array}{l}\text { The river flowing to the East, the waves } \\
\text { washing away all the distinguished } \\
\text { heroes. } \\
\text { There is the west of the old camp, people } \\
\text { say that it was Zhou Yu }{ }^{80} \text { who win the } \\
\text { battle of Red Cliff during the Three } \\
\text { Kingdoms period. } \\
\text { The cloud is exploded by the rocks. } \\
\text { The waves crash against the riverbank. } \\
\text { The waves are stirred like thousands of } \\
\text { white snows. } \\
\text { The majestic landscape is like a beautiful } \\
\text { painting. } \\
\text { Countless heroes appeared during the } \\
\text { Three Kingdom period. } \\
\text { Thinking back to the years when Zhou Yu } \\
\text { was young, he got married with his wife } \\
\text { Xiao Qiao. He already had extraordinary } \\
\text { spirit and heroic insight. } \\
\text { By holding hand-cranked feather fan and } \\
\text { wearing a nylon scarf, and between } \\
\text { laughter, Zhou Yu used clever tricks won } \\
\text { the powerful enemy. All their warships } \\
\text { were burnt to ashes. } \\
\text { Now that I am at the ancient battlefield of } \\
\text { famous Red Cliff War. So, I wandered } \\
\text { back to the past. } \\
\text { People may say, I grow white hair at such } \\
\text { an early age. It may just because I have so } \\
\text { much nostalgia and tenderness. } \\
\text { Life is just a dream. Let's toast to the river } \\
\text { and the moon! }\end{array}$ & $\begin{array}{l}\text { dà jiāng dōng qù, làng táo jìn, } \\
\text { qiān gǔ fēng liú rén wù. } \\
\text { gù lěi xī biān, rén dào shì: sān guó } \\
\text { zhōu láng chì bì. } \\
\text { luàn shí bēng yún, jīng tāo liè àn, } \\
\text { juàn qĩ qiān duī xuě. } \\
\text { jiāng shān rú huà, } \\
\text { yī shí duō shăo háo jié. } \\
\text { yáo xiăng gōng jǐn dāng nián,xiăo } \\
\text { qiáo chū jià liáo,xióng zī ȳing fā. } \\
\text { yŭ shàn lún jīn,tán xiào jiān 、 qiáng } \\
\text { lǔ huī fēi yān miè. } \\
\text { gù guó shén yóu, duō qíng yīng xiào } \\
\text { wǒ,zăo shēng huá fā. } \\
\text { rén jiān rú mèng, yī zūn hái lèi jiāng } \\
\text { yuè. }\end{array}$ \\
\hline
\end{tabular}

\footnotetext{
${ }^{80}$ Zhou Yu was a famous Chinese military general under Warlord Sun Ce and Sun Quan. Xiao Qiao married to Zhou Yu. She was famous for her beauty and grace during the Three Kingdom period.
} 
Composer: Qing Zhu (青主, 1893-1959)

Title: Wo Zhu Changjiang Tou (我住长江头, 1930)

Title translation: I Live Near the Source of the Yangtze River

Poet: Li Zhiyi (李之仪, 1038-1117)

\begin{tabular}{|c|c|c|}
\hline 我住长江头 & I Live Near the Source of the Yangtze River & Wǒ Zhù Chángjiāng Tóu \\
\hline $\begin{array}{l}\text { 我住长江头, } \\
\text { 君住长江尾。 } \\
\text { 日日思君不见君, } \\
\text { 共饮长江水。 } \\
\text { 此水几时休? } \\
\text { 此恨何时已? } \\
\text { 只愿君心似我心, } \\
\text { 定不负相思意。 }\end{array}$ & $\begin{array}{l}\text { I live near the origin of the Yangtze River. } \\
\text { You live near the end of the Yangtze River. } \\
\text { Day after day I miss you, but I cannot see you, } \\
\text { Even though we share the water from the river. } \\
\text { When will the waters stop flowing? } \\
\text { When will this regret end? } \\
\text { I only hope that your heart is like mine, } \\
\text { Never betray our lovesickness. }\end{array}$ & $\begin{array}{l}\text { wǒ zhù chăng jiāng tóu, } \\
\text { jun zhù chăng jiāng wěi. } \\
\text { rì rì sī jun bú jiàn jun, } \\
\text { gòng yǐn zhăng jiāng shuǐ. } \\
\text { cǐ shuǐ jǐ shí xiū? } \\
\text { cǐ hèn hé shí yǐ ? } \\
\text { zhī yuàn jun xīn sì wǒ xīn, } \\
\text { dìng bú fù xiàng sī yì. }\end{array}$ \\
\hline
\end{tabular}


Composer: Xiao Youmei (萧友梅, 1884-1940)

Title: Wen (问, 1922)

Title translation: Question

Poet: Yi Weizhai (易韦斋, 1874-1941)

\begin{tabular}{|c|c|c|}
\hline 问 & Question & Wèn \\
\hline $\begin{array}{l}\text { 你知道你是谁? } \\
\text { 你知道华年如水? } \\
\text { 你知道秋声添得几分憔悴? } \\
\text { 垂垂!垂垂! } \\
\text { 你知道今日的江山, } \\
\text { 有多少凄惶的泪? } \\
\text { 你想想啊: } \\
\text { 对, 对对。 } \\
\text { 你知道你是谁? } \\
\text { 你知道人生如荵? } \\
\text { 你知道秋花开得为何沉醉? } \\
\text { 吹 吹!吹 吹! } \\
\text { 你知道尘世的波澜, } \\
\text { 有几种温良的泪? } \\
\text { 你讲讲啊: } \\
\text { 脆, 脆脆。 }\end{array}$ & $\begin{array}{l}\text { Do you know who you are? } \\
\text { Do you know that time passes like } \\
\text { water? } \\
\text { Do you know that the sound of } \\
\text { Autumn makes people languish? } \\
\text { Sad, Sad! Sad, Sad! } \\
\text { How many tears of sadness in the } \\
\text { country today? } \\
\text { Think about it: } \\
\text { Yes, yes, yes. } \\
\text { Do you know who you are? } \\
\text { Do you know life is like a flower's } \\
\text { core? } \\
\text { Do you know why the flowers in } \\
\text { Autumn are so pretentious? } \\
\text { Blow, Blow! Blow, Blow! } \\
\text { Do you know the crushing waves of } \\
\text { life? } \\
\text { How many tears can be gentle? } \\
\text { You say it: } \\
\text { Crisp, crisp, crisp. }\end{array}$ & 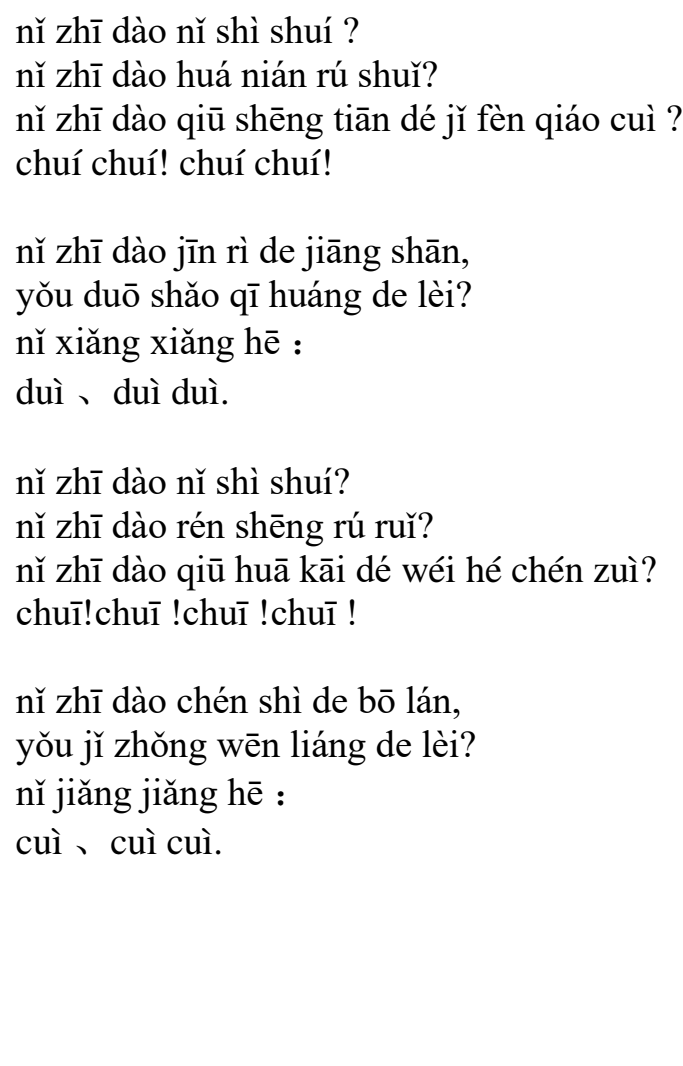 \\
\hline
\end{tabular}


Composer: Zhao Yuanren (赵元任, 1892-1982)

Title: Shang Shan (上山, 1926)

Title translation: Climbing the Mountain

Poet: Hushi (胡适, 1891-1962)

\begin{tabular}{|c|c|c|}
\hline 上山 & Climbing the Mountain & Shàng Shān \\
\hline $\begin{array}{l}\text { “努力!努力!努力往上跑!” } \\
\text { 我头也不回呀, } \\
\text { 汗也不擦, } \\
\text { 拼命地爬上山去。 } \\
\text { “半山了! } \\
\text { 努力!努力往上跑!” } \\
\text { 上面已沒有路, } \\
\text { 我手攀著石上的青藤, } \\
\text { 脚尖抵住岩石縫裡的小树, } \\
\text { 一步一步地爬上山去。 } \\
\text { “小心点! 小心点! 小心点! } \\
\text { 努力, 努力! 努力往上跑!” } \\
\text { 树椿扯破了我的衫袖, } \\
\text { 荊棘刺伤了我的双手, } \\
\text { 我好容易打开了一条线路爬 } \\
\text { 上山去。 } \\
\text { “好了, 好了, 上面就是平路 } \\
\text { 了， } \\
\text { 努力!努力!努力望上跑!” } \\
\text { 上面果然是平坦的路, } \\
\text { 有好看的野花, 有遮阴的老 } \\
\text { 树, } \\
\text { 但是我可倦了, 衣服都被汗湿 } \\
\text { 遍了 } \\
\text { 四肢都觉软了, 我在树下睡 } \\
\text { 倒, } \\
\text { 闻著那扑鼻的草香, } \\
\text { 便昏昏沉沉的睡了一觉。 } \\
\text { 睡醒来時, 天已黑了, } \\
\text { 路已行不得了, }\end{array}$ & $\begin{array}{l}\text { "Work hard! Work hard! Keep } \\
\text { Climbing!" } \\
\text { I don't turn back! } \\
\text { I can't even wipe the sweat of my brow, } \\
\text { Because I'm struggling to climb the } \\
\text { mountain. } \\
\text { "Already Halfway! } \\
\text { Work hard! Work hard to run!" } \\
\text { There is no road above, } \\
\text { I climbed the green vine on the stone. } \\
\text { The toes touch the small tree in the crack } \\
\text { of the rock. } \\
\text { Take it step by step and climb up the } \\
\text { mountain. } \\
\text { "Be careful! Be careful! Be careful! } \\
\text { work hard! Try to run up!" } \\
\text { The stump broke my sleeves. } \\
\text { The thorns stabbed my hands, } \\
\text { I easily opened a line and climbed up the } \\
\text { mountain. } \\
\text { "Ok, well, the top of the mountain is a } \\
\text { flat road, } \\
\text { Work hard! Work hard! Work hard to } \\
\text { run!" } \\
\text { The top of the mountain is a flat road, } \\
\text { There are beautiful wildflowers and } \\
\text { shady old trees. } \\
\text { But I am tired, my clothes are all sweaty. } \\
\text { My limbs feel weak, I fall asleep under } \\
\text { the tree. } \\
\text { Smelled the smell of the grass, } \\
\text { Then fell asleep and slept. } \\
\text { When I woke up, it was already dark. } \\
\text { I had to stop climbing, because } \\
\text { the road had disappeared in the dark. } \\
\text { a }\end{array}$ & 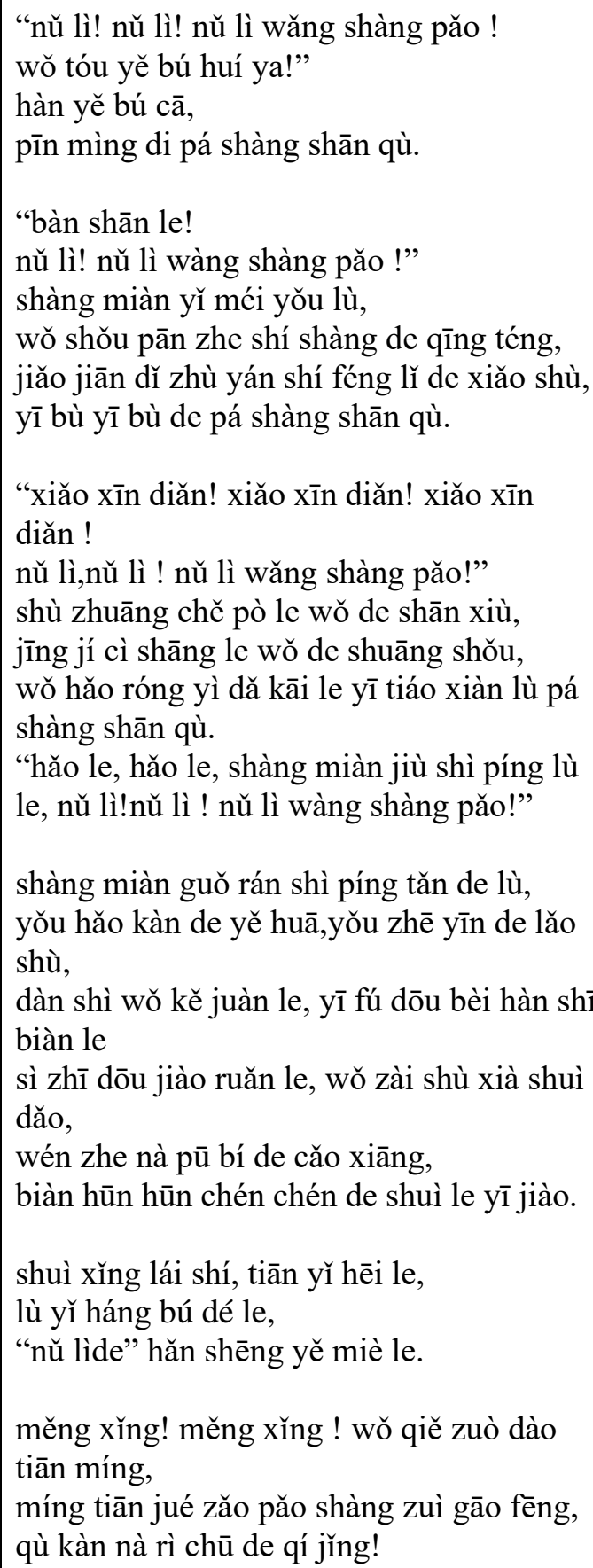 \\
\hline
\end{tabular}




\begin{tabular}{|l|l|l|}
\hline "努力"的喊声也灭了。 & $\begin{array}{l}\text { My shouts of “effort” had also } \\
\text { dissipated. }\end{array}$ \\
$\begin{array}{l}\text { 猛省!猛省!我且坐到天明, } \\
\text { 明天绝早跑上最高峰, } \\
\text { 去看那日出的奇景! }\end{array}$ & $\begin{array}{l}\text { Wake up! Wake up! I am sitting until the } \\
\text { sun rises, } \\
\text { I will go to the highest peak early } \\
\text { tomorrow, } \\
\text { Go and see the wonders of the sunrise! }\end{array}$ & \\
\hline
\end{tabular}


Composer: Zhao Yuanren (赵元任, 1892-1982)

Title: Ting Yu (听雨, 1927)

Title translation: Listening to the Rain

Poet: Liu Bannong (刘半农, 1891-1934)

\begin{tabular}{|l|l|l|}
\hline 听雨 & Listening to the Rain & Tīng Yǔ \\
\hline $\begin{array}{l}\text { 今日我北地将半年, } \\
\text { 今日初听一宵雨, } \\
\text { 若移此雨在江南, } \\
\text { 故园新笋添几许。 }\end{array}$ & $\begin{array}{l}\text { I have been in the Northern land for } \\
\text { nearly half a year, } \\
\text { Today is the first time I experienced an } \\
\text { overnight rain here, } \\
\text { If the rain moves to the Jiangnan region, } \\
\text { Many bamboo shoots will grow in the } \\
\text { homeland. }\end{array}$ & $\begin{array}{l}\text { wǒn lái běi dì jiāng bàn tìng yià xiāo yǔn, } \\
\text { ruò yí cí yǔ zài jiāng nán, } \\
\text { gù yuán xīn sǔn tiān jǐ xǔ。 }\end{array}$ \\
\hline
\end{tabular}


Composer: Zhao Yuanren (赵元任, 1892-1982)

Title: Jiao Wo Ru He Bu Xiang Ta (教我如何不想他, 1926)

Title translation: How Can I Keep from Thinking of You?

Poet: Liu Bannong (刘半农, 1891-1934)

\begin{tabular}{|c|c|c|}
\hline 教我如何不想他 & How Can I Keep from Thinking of You? & Jiào Wǒ Rú Hé Bù Xiăng Tā \\
\hline $\begin{array}{l}\text { 天上飘着些微云, } \\
\text { 地上吹着些微风, } \\
\text { 啊 } \\
\text { 微风吹动了我头发, } \\
\text { 叫我如何不想他? } \\
\text { 月光恋爱着海洋, } \\
\text { 海洋恋爱着月光。 } \\
\text { 啊 } \\
\text { 这般蜜也似的银夜, } \\
\text { 教我如何不想他? } \\
\text { 水面落花慢慢流, } \\
\text { 水底鱼儿慢慢游。 } \\
\text { 啊 } \\
\text { 燕子你说些什么话? } \\
\text { 叫我如何不想他? } \\
\text { 枯树在冷风里摇, } \\
\text { 野火在暮色中烧。 } \\
\text { 啊 } \\
\text { 西天还有些儿残霞, } \\
\text { 叫我如何不想他? }\end{array}$ & $\begin{array}{l}\text { There are some clouds in the sky, } \\
\text { There was a breeze on the ground. } \\
\text { Ah } \\
\text { The breeze blows my hair, } \\
\text { How can I keep from thinking of you? } \\
\text { Moonlight is in love with the ocean, } \\
\text { The ocean is in love with the moonlight. } \\
\text { Ah } \\
\text { This love is like a silver night, } \\
\text { How can I keep from thinking of you? } \\
\text { The flowers flowing on the water slowly } \\
\text { drift away, } \\
\text { At the bottom is a fish swimming slowly. } \\
\text { Ah } \\
\text { A Swallow, what did you just say? } \\
\text { How can I keep from thinking of you? } \\
\text { The withered tree shakes in the cold wind, } \\
\text { The wildfire burns in the twilight. } \\
\text { Ah } \\
\text { There are still red clouds in the West. } \\
\text { How can I keep from thinking of you? }\end{array}$ & $\begin{array}{l}\text { tiān shàng piāo zhe xiē wēi yún, } \\
\text { dì shàng chuī zhe xiē wēi fēng, } \\
\text { a } \\
\text { wēi fêng chuī dòng le wǒ de tóu } \\
\text { fā, } \\
\text { jiào wǒ rú hé bú xiăng tā? } \\
\text { yuè guāng liàn ài zhe hăi yáng, } \\
\text { hăi yáng liàn ài zhe yuè guāng. } \\
\text { a } \\
\text { zhè bān mì yě sì de yín yè, } \\
\text { jiāo wǒ rú hé bú xiăng tā? } \\
\text { shuǐ miàn luò huā màn màn liú, } \\
\text { shuǐ dǐ yú er màn màn yóu. } \\
\text { a } \\
\text { yàn zǐ nǐ shuō xiē shén mehuà? } \\
\text { jiào wǒ rú hé bú xiăng tā? } \\
\text { kū shù zài lěng fēng lî̀ yáo, } \\
\text { yě huǒ zài mù sè zhōng shāo. } \\
\text { a } \\
\text { xī tiān hái yǒu xiē er cán xiá, } \\
\text { jiào wǒ rú hé bú xiăng tā? }\end{array}$ \\
\hline
\end{tabular}


Composer: Zhao Yuanren (赵元任, 1892-1982)

Title: Qiu Zhong (秋钟, 1922)

Title translation: The Autumn Bell

Poet: Zhao Yuanren (赵元任, 1892-1982)

\begin{tabular}{|c|c|c|}
\hline 秋钟 & The Autumn Bell & Qiū Zhōng \\
\hline $\begin{array}{l}\text { 钟一声一声地响, } \\
\text { 风一阵一阵地吹, } \\
\text { 吹到天色渐渐地暗了, } \\
\text { 钟声也断了, } \\
\text { 耳朵里还像似有屑屑屑屑, } \\
\text { 吹来吹去, } \\
\text { 飞来飞去的落叶, } \\
\text { 冬冬冬的钟声, } \\
\text { 似连似断, } \\
\text { 和那轰轰轰的风声, } \\
\text { 似有似绝。 }\end{array}$ & $\begin{array}{l}\text { The bell rung continuously one sound } \\
\text { after another, } \\
\text { The wind blew one gust after another, } \\
\text { It blew until the dusk. } \\
\text { The sound of the bell stopped, } \\
\text { The ears can still hear the sounds of the } \\
\text { wind, blowing to and fro, } \\
\text { The leaves fly to and fro, } \\
\text { The sounds of the bell "Dong, Dong, } \\
\text { Dong," } \\
\text { It may ring or it may stop, } \\
\text { And the sound of the wind "Long, Long, } \\
\text { Long" } \\
\text { It may blow, or it may end. }\end{array}$ & $\begin{array}{l}\text { zhōng ȳi shēng ȳì shēng dì xiăng, } \\
\text { fēng yī zhèn yī zhèn dì chūi, } \\
\text { chuī dào tiān sè jiàn jiàn dì àn } \\
\text { liăo, } \\
\text { zhōng shēng yě duàn liăo, } \\
\text { ěr duǒ lǐ huán xiàng sì yǒu xiè xiè } \\
\text { xiè xiè, } \\
\text { chuī lái chuī qù, } \\
\text { fēi lái fèi qù dí luò yè, } \\
\text { dōng dōng dōng dí zhōng shēng, } \\
\text { sì lián sì duàn, } \\
\text { hé nà hōng hōng hōng dí fēng } \\
\text { shēng, } \\
\text { sì yǒu sì jué. }\end{array}$ \\
\hline
\end{tabular}


Composer: Zhao Yuanren (赵元任, 1892-1982)

Title: Mai Bu Yao (卖布谣, 1922)

Title translation: Fabric Selling Ballad

Poet: Liu Da Bai (刘大白, 1880-1932)

\begin{tabular}{|c|c|c|}
\hline 卖布谣 & Fabric Selling Ballad & Mài Bù Yáo \\
\hline $\begin{array}{l}\text { 嫂嫂织布, } \\
\text { 哥哥卖布。 } \\
\text { 卖布买米, } \\
\text { 有饭落肚。 } \\
\text { 嫂嫂织布, } \\
\text { 哥哥卖布。 } \\
\text { 小弟弟裤破, } \\
\text { 没布补裤。 } \\
\text { 嫂嫂织布, } \\
\text { 哥哥卖布。 } \\
\text { 是谁买布? } \\
\text { 前村财主。 } \\
\text { 土布粗, } \\
\text { 洋布细。 } \\
\text { 洋布便宜, } \\
\text { 财主欢喜。 } \\
\text { 土布没人要, } \\
\text { 饿倒了哥哥嫂嫂! }\end{array}$ & $\begin{array}{l}\text { My sister-in-law weaves cloth, } \\
\text { My brother sells cloth. } \\
\text { Selling cloth to buy rice, } \\
\text { So, we have a meal. } \\
\text { My sister-in-law weaves cloth, } \\
\text { My brother sells cloth. } \\
\text { My Brother's pants are broken, } \\
\text { But we have no cloth to patch the pants. } \\
\text { My sister-in-law weaves cloth, } \\
\text { My brother sells cloth. } \\
\text { Who buys all this cloth, } \\
\text { The village's rich men and landlords. } \\
\text { The local cloth is rough, } \\
\text { The foreign cloth is fine. } \\
\text { The foreign cloth is cheap, } \\
\text { And rich men like it. } \\
\text { Nobody wants local cloth. } \\
\text { My brothers and sisters go hungry! }\end{array}$ & $\begin{array}{l}\text { săo săo zhī bù, } \\
\text { gē gē mài bù. } \\
\text { mài bù măi mǐ, } \\
\text { yŏu fàn luò dù. } \\
\text { săo săo zhī bù, } \\
\text { gē gē mài bù. } \\
\text { xiao dì dì kù pò, } \\
\text { méi bù bǔ kù. } \\
\text { săo săo zhī bù, } \\
\text { gē gē mài bù. } \\
\text { shì shuí măi bù, } \\
\text { qián cūn cái zhǔ yǔ dì zhǔ. } \\
\text { tǔ bù cū, } \\
\text { yáng bù xì. } \\
\text { yáng bù biàn yí, } \\
\text { cái zhǔ huān xí. } \\
\text { tǔ bù méi rén yào, } \\
\text { è dăo gē gē săo săo! }\end{array}$ \\
\hline
\end{tabular}


Composer: Zhao Yuanren (赵元任, 1892-1982)

Title: Ye Shi Wei Yun (也是微云, 1926)

Title translation: Also, Are the Smallest Clouds

Poet: Hu Shi (胡适, 1891-1962)

\begin{tabular}{|c|c|c|}
\hline 也是微云 & Also, Are the Smallest Clouds & Yě Shì Wēi Yún \\
\hline $\begin{array}{l}\text { 也是微云, } \\
\text { 也是微云过后月光明, } \\
\text { 只不见去年得游伴, } \\
\text { 也没有当日的心情。 } \\
\text { 不愿勾起相思, } \\
\text { 不敢出门看月; } \\
\text { 偏偏月进窗来, } \\
\text { 害我相思一夜。 }\end{array}$ & $\begin{array}{l}\text { Also, are the smallest clouds. } \\
\text { Also, the moonlight through the cloud. } \\
\text { But I am not with my lover from last year. } \\
\text { So gone are my moods from the past. } \\
\text { I do not want to evoke lovesickness, } \\
\text { Or to watch the moon outside. } \\
\text { But the moonlight comes through windows, } \\
\text { Making me have lovesickness for a whole night. }\end{array}$ & $\begin{array}{l}\text { yě shì wēi yún, } \\
\text { yě shì wēi yún guò hòu yuè guāng míng, } \\
\text { zhī bú jiàn qù nián dé yóu bàn, } \\
\text { yě méi yǒu dāng rì de xīn qíng. } \\
\text { bú yuàn gōu qî̀ xiàng sī, } \\
\text { bú găn chū mén kàn yuè; } \\
\text { piān piān yuè jìn chuāng lái, } \\
\text { hài wǒ xiàng sī yī yè. }\end{array}$ \\
\hline
\end{tabular}




\section{Appendix II : Lyrics and Translations for Chinese Art Songs from the 1930s}

Composer: Chen Tianhe (陈田鹤, 1911-1955)

Title: Chun Gui He Chu (春归何处, 1931)

Title translation: Where does Spring Belong

Poet: Huang Tingjian (黄庭坚, 1045-1105)

\begin{tabular}{|c|c|c|}
\hline 春归何处 & Where does Spring Belong & Chūn Guī Hé Chǔ \\
\hline $\begin{array}{l}\text { 春归何处? } \\
\text { 寂寞无行路。 } \\
\text { 若有人知春去处, } \\
\text { 唤取归来同住。 } \\
\text { 春无踪迹谁知? } \\
\text { 除非问取黄丽鸟。 } \\
\text { 百啭无人能解, } \\
\text { 因风飞过菩薇。 }\end{array}$ & $\begin{array}{l}\text { Where does Spring belong? } \\
\text { We can't find its footprint on the lonely path, } \\
\text { If someone knows any news about Spring, } \\
\text { tell her to come back and live with us. } \\
\text { Has anyone seen any trace of Spring? } \\
\text { If anyone wants to know, just ask the oriole bird. } \\
\text { The oriole keeps twittering } \\
\text { a hundred times, } \\
\text { But who can understand its meaning? } \\
\text { Look, the oriole is riding the wind, } \\
\text { Flying over the roses. }\end{array}$ & $\begin{array}{l}\text { chūn guī hé chù? } \\
\text { jì mò wú háng lù. } \\
\text { ruò yǒu rén zhī chūn qù chù, } \\
\text { huàn qǔ guī lái tóng zhù. } \\
\text { chūn wú zōng jì shuí zhī? } \\
\text { chú fêi wèn qǔ huáng lí. } \\
\text { băi zhuàn wú rén néng jiě, } \\
\text { yīn fēng fêi guò qiáng wēi. }\end{array}$ \\
\hline
\end{tabular}


Composer: Chen Tianhe (陈田鹤, 1911-1955)

Title: Shan Zhong (山中, 1934)

Title translation: In the Mountain

Poet: Xu Zhi Mo (徐志摩, 1903-1987)

\begin{tabular}{|c|c|c|}
\hline 山中 & In the Mountain & Shān Zhōng \\
\hline $\begin{array}{l}\text { 处处是一片静, } \\
\text { 听市谣围抱, } \\
\text { 织成一地松影, } \\
\text { 看当头月好! } \\
\text { 不知今夜山中, } \\
\text { 是何等光景; } \\
\text { 想也有月有松, } \\
\text { 有更深的静。 } \\
\text { 我原攀附月色, } \\
\text { 化一阵清风, } \\
\text { 吹醒群松春醉, } \\
\text { 去山中浮动。 } \\
\text { 吹下一针新碧, } \\
\text { 掉在你窗前, } \\
\text { 轻柔如同叹息, } \\
\text { 不惊你安眠! }\end{array}$ & $\begin{array}{l}\text { Everywhere in the mountains is silent, } \\
\text { Surrounded by the city noise, } \\
\text { The shadow of the pines woven into the ground. } \\
\text { Watching the full moon over my head; } \\
\text { What a beautiful view! } \\
\text { I'm thinking about the moon and the pines, } \\
\text { Where there is deeper silence. } \\
\text { I wish to go with the moon, } \\
\text { By turning into a gust of wind, } \\
\text { I will wake all the drunk pines to sway in the mountain. } \\
\text { I will blow one leave of the new pine, } \\
\text { And land in front of your window, } \\
\text { Soft as one sigh, } \\
\text { Not disturbing your rest! }\end{array}$ & $\begin{array}{l}\text { chù chù shì yī piàn jìng, } \\
\text { tîng shì yáo wéi bào, } \\
\text { zhī chéng yì dì sōng yǐng, } \\
\text { kàn dāng tóu yuè hăo! } \\
\text { bú zhī jīn yè shān zhōng, } \\
\text { shì hé děng guāng jǐng; } \\
\text { xiǎng yě yǒu yuè yǒu sōng, } \\
\text { yǒu gèng shēn di jìng. } \\
\text { wǒ yuán pān fù yuè sè, } \\
\text { huà yī zhèn qīng fêng, } \\
\text { chuī xǐng qún sōng chūn zuì, } \\
\text { qù shān zhōng fú dòng. } \\
\text { chuī xià yì zhēn xīn bì, } \\
\text { diào zài nǐ chuāng qián, } \\
\text { qīng róu rú tóng tàn xī, } \\
\text { bú jīng nǐ ān mián! }\end{array}$ \\
\hline
\end{tabular}


Composer: Chen Tianhe (陈田鹤, 1911-1955)

Title: Qiu Tian de Meng (秋天的梦, 1936)

Title translation: Autumn's Dream

Poet: Dai Wangshu (戴望舒, 1905-1950)

\begin{tabular}{|c|c|c|}
\hline 秋天的梦 & Autumn's Dream & Qiū Tiān De mèng \\
\hline $\begin{array}{l}\text { 迢遥的牧女的羊铃, } \\
\text { 摇落了轻的树叶。 } \\
\text { 那是窈家的牧女之恋。 } \\
\text { 于是我的梦是静静地来了; } \\
\text { 但却载着沉重的昔日, } \\
\text { 哦现在, 我有一些儿寒冷, } \\
\text { 一些儿寒冷, 和一些儿忧郁。 }\end{array}$ & $\begin{array}{l}\text { The Goat bell of the shepherd girl was in } \\
\text { the distance, } \\
\text { It made the light leaves fall. } \\
\text { The Autumn's dream was light, } \\
\text { It was the beautiful shepherd girl's love. } \\
\text { So, my dream came gently; } \\
\text { But it carried a heavy burden from } \\
\text { yesterday, } \\
\text { Oh, now, I feel a little chill, } \\
\text { a little chill, and a little sad. }\end{array}$ & $\begin{array}{l}\text { tiáo yáo di mù nü di yáng líng, } \\
\text { yáo luò le qīng di shù yè. } \\
\text { qiū tiān di mèng shì qīng de, } \\
\text { nà shì yăo tiăo di mù nü zhī liàn. } \\
\text { yú shì wǒ de mèng shì jìng jìng dì lái le; } \\
\text { dàn què zăi zhe chén zhòng di xî̀ rì, } \\
\text { ò xiàn zài, wǒ yǒu yî xi ēr hán lěng, } \\
\text { yī xiēr hán lěng. hé yī xiēr yōu yù. }\end{array}$ \\
\hline
\end{tabular}


Composer: Chen Tianhe (陈田鹤, 1911-1955)

Title: Cai Sang Qu (采桑曲, 1930s)

Title translation: The Song of Picking Mulberry Leaves

Poet: Zheng Qi (郑起, 1199-1262)

\begin{tabular}{|c|c|c|}
\hline 采桑曲 & The Song of Picking Mulberry Leaves & Căi Sāng Qū \\
\hline $\begin{array}{l}\text { 晴采桑, } \\
\text { 雨采桑, } \\
\text { 田头陌上家家忙。 } \\
\text { 去年养䖯十分熟, } \\
\text { 桑姑只着麻衣裳。 }\end{array}$ & $\begin{array}{l}\text { Picking Mulberry leaves on a Sunny day, } \\
\text { Picking mulberry leaves on a rainy day, } \\
\text { On the farmland, every family is busy. } \\
\text { Last year, our mulberry business was prospering. } \\
\text { But the women in our family can only afford linen. }\end{array}$ & $\begin{array}{l}\text { qíng căi sāng, } \\
\text { yǔ căi sāng, } \\
\text { tián tóu mò shàng jiā jiā máng } \\
\text { qù nián yăng cán shí fèn shú, } \\
\text { sāng gū zhī zhuó má yī shang。 }\end{array}$ \\
\hline
\end{tabular}


Composer: He Luding (贺绿汀, 1903-1999)

Title: Jialing Jiang Shang (嘉陵江上, 1939)

Title translation: On the Jialing River

Poet: Duan Mu Hong Liang（端木蕻良, 1912-1996)

\begin{tabular}{|c|c|c|}
\hline 嘉陵江上 & On the Jialing River & Jiālíng Jiāng Shàng \\
\hline $\begin{array}{l}\text { 那一天, 敌人打到了我的村庄, } \\
\text { 我便失去了我的田舍、家人和 } \\
\text { 牛羊, } \\
\text { 如今我徘徊在嘉陵江上, } \\
\text { 我仿佛闻到故乡泥土的芳香; } \\
\text { 一样的流水,一样的月亮, } \\
\text { 我已失去了一切欢笑和梦想。 } \\
\text { 江水每夜鸣咽地流过, } \\
\text { 都仿佛流在我的心上! } \\
\text { 我必须回到我的故乡, } \\
\text { 为了那没有收割的菜花, } \\
\text { 和那饿瘦了的羔羊。 } \\
\text { 我必须回去, } \\
\text { 从敌人的枪弹底下回去; } \\
\text { 我必须回去, } \\
\text { 从敌人的刺刀丛里回去。 } \\
\text { 把我那打胜仗的刀枪, } \\
\text { 放在我生长的地方! }\end{array}$ & $\begin{array}{l}\text { That day, the enemy invaded our } \\
\text { village, } \\
\text { I lost my lands, my family and my } \\
\text { cows and goats, } \\
\text { Now I am wondering on the Jialing } \\
\text { River, } \\
\text { As if I can smell the mud in my } \\
\text { hometown. } \\
\text { The same stream, the same moon, } \\
\text { I lost all my joy and dreams. } \\
\text { The river is weeping every night, as } \\
\text { if it is flowing in my heart! } \\
\text { I have to go back to my home, } \\
\text { Because the cauliflower needs } \\
\text { harvesting, } \\
\text { and the goat needs feeding. } \\
\text { I have to go back, } \\
\text { Go back under the enemy's bullets. } \\
\text { I have to go back, } \\
\text { Go back under the enemy's bayonet. } \\
\text { I have to put my winning sword and } \\
\text { gun where I grew up! }\end{array}$ & $\begin{array}{l}\text { nà yī tiān, dí rén dă dào le wǒ di cūn zhuāng, } \\
\text { wǒ biàn shī qù le wǒ di tián shě,jiā rén hé niú } \\
\text { yáng, } \\
\text { rú jīn wǒ pái huái zài jiā líng jiāng shàng, } \\
\text { wǒ făng fó wén dào gù xiāng ní tǔ di fāng } \\
\text { xiāng; } \\
\text { yī yàng di liú shuǐ,yī yàng di yuè liàng, } \\
\text { wǒ yî shī qù le yī qiē huān xiào hé mèng } \\
\text { xiăng. } \\
\text { jiāng shuǐ měi yè wū yān dì liú guò, } \\
\text { dōu făng fó liú zài wǒ di xīn shang! } \\
\text { wǒ bì xū huí dào wǒ di gù xiāng, } \\
\text { wéi le nà méi yǒu shōu gē di cài huā, } \\
\text { hé nà è shòu le di gāo yáng. } \\
\text { wǒ bì xū huí qù, } \\
\text { cóng dí rén di qiāng dàn dĩ xià huí qù; } \\
\text { wó bì xū huí qù, } \\
\text { cóng dí rén di cì dāo cóng lǐ huí qù. } \\
\text { bǎ wǒ nà dă shèng zhàng di dāo qiāng, } \\
\text { fàng zài wǒ shēng zhăng di dì fang! }\end{array}$ \\
\hline
\end{tabular}


Composer: Huang Zi (黄自, 1904-1953)

Title: Meigui San Yua (玫瑰三愿, 1932)

Title Translation: The Three Wishes of the Rose

Poet: Long Qi (龙t, 1902-1966)

\begin{tabular}{|c|c|c|}
\hline 玫瑰三愿 & The Three Wishes of the Rose & Méiguī Sān Yuàn \\
\hline $\begin{array}{l}\text { 玫瑰花, 玫瑰花, } \\
\text { 烂开在碧栏杆下, } \\
\text { 玫瑰花, 玫瑰花, } \\
\text { 烂开在碧栏杆下。 } \\
\text { 我愿那妒我的无情风雨 } \\
\text { 莫吹打, } \\
\text { 我愿那爱我的多情游客 } \\
\text { 莫攀摘! } \\
\text { 我愿那红颜常好不凋谢 }{ }^{81}, \\
\text { 好教我留芳华。 }\end{array}$ & $\begin{array}{l}\text { A Rose, a Rose, } \\
\text { A brilliant blossom by the green fence, } \\
\text { A Rose, a Rose, } \\
\text { A brilliant blossom by the green fence. } \\
\text { I wish the jealous and ruthless wind and rain } \\
\text { would not blow me down, } \\
\text { I wish the passionate tourist wouldn't pluck me } \\
\text { away, } \\
\text { I wish my beauty would never fade, } \\
\text { So, I could keep my youth forever. }\end{array}$ & $\begin{array}{l}\text { méi guī huā, méi guī huā, } \\
\text { làn kāi zài bì lán găn xià, } \\
\text { méi gui huā, méi guī huā, } \\
\text { làn kāi zài bì lán găn xià. } \\
\text { wǒ yuàn nà dù wǒ di wú qíng fēng yǔ } \\
\text { mò chuī dă, } \\
\text { wǒ yuàn nà ài wǒ di duō qíng yóu kè } \\
\text { mò pān zhāi! } \\
\text { wǒ yuàn nà hóng yán cháng hăo bú } \\
\text { diāo xia, } \\
\text { hăo jiāo wǒ liú fāng huá. }\end{array}$ \\
\hline
\end{tabular}

\footnotetext{
${ }^{81}$ The pronunciation is "Xia" not "Xie."
} 
Composer: Huang Zi (黄自, 1904-1953)

Title: Si Xiang (思乡,1932)

Title Translation: Homesick

Poet: Wei Hanzhang (韦瀚章, 1905-1993)

\begin{tabular}{|c|c|c|}
\hline 思乡 & Homesick & Sī Xiāng \\
\hline $\begin{array}{l}\text { 柳丝系绿, } \\
\text { 清明才过了, } \\
\text { 独自个凭栏无语。 } \\
\text { 更那堪墙外鹃啼, } \\
\text { 一声声道:“不如归去!” } \\
\text { 惹起了万种闲情, 满怀 } \\
\text { 别绪. } \\
\text { 问落花: “随渺渺微波 } \\
\text { 是否向南流?” } \\
\text { 我愿与他同去。 }\end{array}$ & $\begin{array}{l}\text { The willow is green, } \\
\text { Qingming } 82 \text { just passed, } \\
\text { I am standing by the fence alone. } \\
\text { I have nothing to say. } \\
\text { The cuckoo bird is calling outside. It is saying, "It's } \\
\text { better to go back to your hometown." } \\
\text { It caused me thousands of emotions. } \\
\text { Now I am full of the desire to leave. } \\
\text { I ask the falling flowers on the river: 'Is the river } \\
\text { flowing to the south? Should I follow the small } \\
\text { waves of the river." } \\
\text { I want to go with it! }\end{array}$ & $\begin{array}{l}\text { liǔ sī xì lǜ, } \\
\text { qīng míng cái guò liao, } \\
\text { dú zì gè píng lán wú yǔ. } \\
\text { gèng nà kān qiáng wài juān tí, } \\
\text { yī shēng shēng dào: "bú rú guī } \\
\text { qù!"” } \\
\text { rě qǐ le wàn zhǒng xián qíng, } \\
\text { măn huái bié xù . } \\
\text { wèn luò huā: "suí miăo miăo } \\
\text { wēi bō } \\
\text { shì fŏu xiàng nán liú?" } \\
\text { wǒ yuàn yǔ tā tóng qù! }\end{array}$ \\
\hline
\end{tabular}

${ }^{82}$ Qingming is a festival in China. People commemorate their ancestors, like during the day of the dead. 
Composer: Huang Zi (黄自, 1904-1953)

Title: Chun Si Qu (春思曲, 1932)

Title Translation: Song of Spring Thoughts

Poet: Wei Hanzhang (韦瀚章, 1905-1993)

\begin{tabular}{|c|c|c|}
\hline 春思曲 & Song of Spring Thoughts & Chūn Sī Qū \\
\hline $\begin{array}{l}\text { 潇潇夜雨滴阶前, } \\
\text { 寒衾孤枕未成眠。 } \\
\text { 今朝揽镜, 应是梨涡浅, } \\
\text { 绿云慵掠, 懒贴花钿。 } \\
\text { 小楼独倚, 怕睹陌头杨 } \\
\text { 柳, 分色上穷边。 } \\
\text { 更妒繁无知双燕, } \\
\text { 吱吱语过花栏前。 } \\
\text { 忆个郎远别已经年, } \\
\text { 恨只恨, 不化成杜宇,唤 } \\
\text { 他快整归鞭。 }\end{array}$ & $\begin{array}{l}\text { The night rain fell quietly, It dropped down to the stone } \\
\text { stairs along the eaves, } \\
\text { With the coldness and loneliness, the wife heard the } \\
\text { raindrops, and could not fall asleep. } \\
\text { The next morning, the wife woke up and looked the } \\
\text { mirror, } \\
\text { She saw a face with a gentle smile, } \\
\text { She lazily used her fingers to pull back her cloud-like } \\
\text { black hair,She was also lazily putting on her "Huadian" } \\
\text { make up. } \\
\text { Standing outside the house, the wife is afraid the willows } \\
\text { on the streets will share their green colors with the } \\
\text { willows near her house. } \\
\text { She is even more afraid to see swallow bird couples, } \\
\text { singing to each other, and flying over the flower bar } \\
\text { together. } \\
\text { After seeing the swallow couple in love, how could the } \\
\text { wife not miss her husband more deeply or avoid being } \\
\text { jealous? } \\
\text { The wife has been separated from her husband for years. } \\
\text { Instead of staying at home, she would rather become a } \\
\text { swallow bird and go off to see her husband. } \\
\text { Then she will ask him to pack his suitcases and ride a } \\
\text { horse home right away. }\end{array}$ & $\begin{array}{l}\text { xiāo xiāo yè yǔ dī jiē qián, } \\
\text { hán qīn gū zhěn wèi chéng } \\
\text { mián。 } \\
\text { jīn zhāo lăn jìng, yīng shì lí wō } \\
\text { qiăn, } \\
\text { lǜ yún yōng luě, lăn tiē huā } \\
\text { diàn. } \\
\text { xiăo lóu dú yǐ, pà dǔ mò tóu } \\
\text { yáng liǔ, fèn sè shàng lián biān. } \\
\text { gèng dù shà wú zhī shuāng yàn, } \\
\text { zì zī yǔ guò huā lán qián. } \\
\text { yì gè láng yuăn bié yǐ jīng nián, } \\
\text { hèn zhī hèn, bú huà chéng dù } \\
\text { yǔ, huàn tā kuài zhěng guī biān. }\end{array}$ \\
\hline
\end{tabular}


Composer: Huang Zi (黄自, 1904-1953)

Title: Hua Fei Hua (花非花, 1933)

Title Translation: Flowers are not Flowers

Poet: Bai Juyi (白居易, 772-846)

\begin{tabular}{|c|c|c|}
\hline 花非花 & Flowers are not Flowers & Huā Fēi Huā \\
\hline $\begin{array}{l}\text { 花非花, 雾非雾; } \\
\text { 夜半来, 天明去。 } \\
\text { 来如春梦几多时, } \\
\text { 去似朝云无受处。 }\end{array}$ & $\begin{array}{l}\text { Flowers are not flowers, } \\
\text { Fog is not fog, } \\
\text { The night comes, the day goes. } \\
\text { When the dream of spring comes, it won't stay long. } \\
\text { When the morning clouds leave, they won't be found again. }\end{array}$ & $\begin{array}{l}\text { huā fēi huā, wù fèi wù; } \\
\text { yè bàn lái, tiān míng qù. } \\
\text { lái rú chūn mèng jǐ duō shí, } \\
\text { qù sì cháo yún wú mì chù. }\end{array}$ \\
\hline
\end{tabular}


Composer: Huang Zi (黄自, 1904-1953)

Title: Ta Xue Xun Mei (踏雪寻梅, 1933)

Title Translation: Stepping in the Snow to Find Plums

Poet: Liu Xue'an (刘雪庵, 1905-1985)

\begin{tabular}{|c|c|c|}
\hline 踏雪寻梅 & Stepping in the Snow to Find Plums & Tà Xuě Xún Méi \\
\hline $\begin{array}{l}\text { 雪雺天晴朗, } \\
\text { 腊梅处处香。 } \\
\text { 骑驴灞桥过, } \\
\text { 铃儿响叮当。 } \\
\text { 响叮当 响叮当, } \\
\text { 响叮当 响叮当。 } \\
\text { 好花采得瓶供养, } \\
\text { 伴我书声琴韵, } \\
\text { 共度好时光。 }\end{array}$ & $\begin{array}{l}\text { The snow stops, the sky is sunny, } \\
\text { The plum blossoms make everywhere smell good. } \\
\text { I ride the donkey past the Pa Bridge, } \\
\text { The donkey's bell rings with the sound "ding dang." } \\
\text { "Ding dang," "ding dang," } \\
\text { "ding dang," "ding dang." } \\
\text { A good flower needs a good vase. } \\
\text { The flower accompanies me by my side, to the sound of my } \\
\text { reading and music making. } \\
\text { We are having a good time together. }\end{array}$ & $\begin{array}{l}\text { xuě jì tiān qíng lăng, } \\
\text { là méi chù chù xiāng. } \\
\text { qí lǘ bà qiáo guò, } \\
\text { líng er xiăng dīng dāng. } \\
\text { xiăng dīng dāng xiăng dīng } \\
\text { dāng, } \\
\text { xiăng dīng dāng xiăng dīng } \\
\text { dāng. } \\
\text { hăo huā căi dé píng gòng yang, } \\
\text { bàn wǒ shū shēng qín yùn, } \\
\text { gòng dù hăo shí guāng. }\end{array}$ \\
\hline
\end{tabular}


Composer: Huang Zi (黄自, 1904-1953)

Title: Xi Feng de Hua (西风的话, 1934)

Title Translation: The Words of the West Wind

Poet: Liao Fushu (廖辅叔,1907-2002)

\begin{tabular}{|c|c|c|}
\hline 西风的话 & The Words of the West Wind & X̄̄ Fēng de Huà \\
\hline $\begin{array}{l}\text { 去年我回去, } \\
\text { 你们刚穿新棉袍, } \\
\text { 今年我来看你们, } \\
\text { 你们变胖又变高, } \\
\text { 你们可记得, } \\
\text { 池里荷花变莲蓬? } \\
\text { 花少不愁没颜色, } \\
\text { 我把树叶都染红。 }\end{array}$ & $\begin{array}{l}\text { Last year, when I came back home, } \\
\text { you had just gotten new coat. } \\
\text { This year, when I came back to see you, } \\
\text { you had become bigger and taller. } \\
\text { Do you still remember, } \\
\text { the lotus in the pond had become a cultivar? }{ }^{83} \\
\text { There are not many flowers left, } \\
\text { so, there is not much color remaining. } \\
\text { Therefore, I (the west wind) will color all the leaves red. }\end{array}$ & $\begin{array}{l}\text { qù nián wǒ huí qù, } \\
\text { nǐ men gāng chuān xīn mián páo, } \\
\text { jīn nián wǒ lái kàn nǐ men, } \\
\text { nǐ men biàn pàng yòu biàn gāo, } \\
\text { nǐ men kě jì dé, } \\
\text { chí lǐ hé huā biàn lián péng? } \\
\text { huā shǎo bú chóu méi yán sè, } \\
\text { wǒ bă shù yè dōu răn hóng. }\end{array}$ \\
\hline
\end{tabular}

${ }^{83}$ When the lotus dies, it becomes the cultivar. The cultivar is a fruit of lotus, which can be eaten or used for medicinal purposes. 
Composer: Huang Zi (黄自, 1904-1953)

Title: Nan Xiang Zi, Deng Jing Kou Beigu Ting You Huai (南乡子・登京口北固亭有怀, 1934)

Title Translation: Nan Xiang Zi, Having Thoughts while Boarding Beigu Pavilion at the City of Jingkou

Poet: Xin Qiji (辛弃疾, 1140-1207)

\begin{tabular}{|c|c|c|}
\hline 南乡子 & Nan Xiang Zi, Deng Jing Kou Beigu Ting You Huai & $\begin{array}{l}\text { Nán Xiāng Zǐ • Dēng Jīng Kǒu } \\
\text { Běigù Tíng Yǒu Huái }\end{array}$ \\
\hline $\begin{array}{l}\text { 何处望神州? } \\
\text { 满眼风光北固楼, } \\
\text { 千古兴亡多少事? } \\
\text { 悠悠, } \\
\text { 不尽长江滚滚流。 } \\
\text { 年少万自鏱, } \\
\text { 坐断东南战未休。 } \\
\text { 天下英雄谁敌手? } \\
\text { 曹刘, } \\
\text { 生子当如孙仲谋。 }\end{array}$ & $\begin{array}{l}\text { Where can I go to find the prosperous land in China? } \\
\text { I can only find magnificent land near Beigu Pavilion, } \\
\text { Thousands of years, nobody knows how much prosperity we } \\
\text { lost and what a decline we saw. } \\
\text { Long time, } \\
\text { Just like the Yang'ze River flows and goes. } \\
\text { Thinking back to the prosperous days, how brave and } \\
\text { powerful was Sun Quan. } \\
\text { In his youth, } \\
\text { he commanded thousands of soldiers, } \\
\text { and occupied the entire region of Jiangnan. } \\
\text { Who was worthy to be his opponent? } \\
\text { Only Cao Cao }{ }^{85} \text { and Liu Bei }{ }^{86} \text { were worthwhile opponents to } \\
\text { him. } \\
\text { People all wish to raise their child to be like Sun Quan. }\end{array}$ & $\begin{array}{l}\text { hé chù wàng shén zhōu? } \\
\text { măn yăn fêng guāng běi gù lóu, } \\
\text { qiān gŭ xìng wáng duō shăo shì? } \\
\text { yōu yōu, } \\
\text { bú jìn zhăng jiāng gǔn gŭn liú } \\
\text { nián shăo wàn dōu móu, } \\
\text { zuò duàn dōng nán zhàn wèi xiū. } \\
\text { tiān xià yīng xióng shuí dí shǒu? } \\
\text { cáo liú, } \\
\text { shēng zǐ dāng rú sūn zhòng móu. }\end{array}$ \\
\hline
\end{tabular}

\footnotetext{
${ }^{84}$ Sun Quan (182-252), also called Sun Zhongmou. He was the founder of the state of Eastern Wu during the Three Kingdoms period.

${ }^{85}$ Cao Cao (155-220), founder of Cao Wei in the Three Kingdoms Period.

${ }^{86}$ Liu Bei (161-223), founded of Shu Han in the Three Kingdoms period.
} 
Composer: Huang Zi (黄自, 1904-1953)

Title: Dian Jiang Chun, Fu Deng Lou (点㖓唇・赋登楼, 1934)

Title Translation: Dian Jiang Chun, Ode to Ascending the Tower

Poet: Wang Zhuo (王昫)

\begin{tabular}{|c|c|c|}
\hline 点㖓唇 & Dian Jiang Chun, Ode to Ascending the Tower & Diăn Jiàng Chún • Fù Dēng Lóu \\
\hline $\begin{array}{l}\text { 休惜余春! } \\
\text { 试来把酒留春住, } \\
\text { 问春无语, } \\
\text { 穷卷西山雨。 } \\
\text { 一掬愁心, } \\
\text { 强欲登高赋。 } \\
\text { 山无数。 } \\
\text { 烟波无数。 } \\
\text { 不放春归去。 }\end{array}$ & $\begin{array}{l}\text { When I am taking a break, I feel like there are not many } \\
\text { spring days remaining! } \\
\text { I tried to get spring to stay, } \\
\text { using good wine. } \\
\text { I asked spring to stay, } \\
\text { but she remained silent. } \\
\text { I rolled up the curtain and looked at the west mountains in the } \\
\text { rain. } \\
\text { When I feel sadness, } \\
\text { I must go and climb to the top of the mountain and write a } \\
\text { poem. } \\
\text { The mountain peaks are countless, } \\
\text { The mist of the rain is countless, } \\
\text { Maybe the mist can make spring stay. }\end{array}$ & $\begin{array}{l}\text { xiū xī yú chūn! } \\
\text { shì lái bǎ jiǔ liú chūn zhù, } \\
\text { wèn chūn wú yǔ, } \\
\text { lián juàn xī shān yǔ. } \\
\text { yī jū chóu xīn, } \\
\text { qiáng yù dēng gāo fù. } \\
\text { shān wú shù. } \\
\text { yān bō wú shù. } \\
\text { bú fàng chūn guī qù. }\end{array}$ \\
\hline
\end{tabular}


Composer: Jiang Dingxian (江定仙, 1912-2000)

Title: Sui Yue You You (岁月悠悠, 1936)

Title translation: Years Long ago

Poet: Huang Jiamo (黄嘉谟, 1916-2004)

\begin{tabular}{|c|c|c|}
\hline 岁月悠悠 & Years Long ago & Suì Yuè Yōu Yōu \\
\hline $\begin{array}{l}\text { 岁月悠悠, } \\
\text { 旧情付水流。 } \\
\text { 忆去年今日, } \\
\text { 送你上归舟。 } \\
\text { 江风拂杨柳, } \\
\text { 一日不见如三秋。 } \\
\text { 岁月悠悠, } \\
\text { 旧情不可留。 } \\
\text { 临江空惆怅, } \\
\text { 胜地忆旧游, } \\
\text { 江风逐水流, } \\
\text { 旧情不堪重回首。 }\end{array}$ & $\begin{array}{l}\text { Years long ago, } \\
\text { old love went away with the flowing water. } \\
\text { I remember last year, } \\
\text { I said goodbye to you by the riverboat. } \\
\text { The wind is blowing in the willows. } \\
\text { I have only been separated from you for one day, but it } \\
\text { feels like it has been three years. } \\
\text { Years long ago, } \\
\text { Old love wouldn't stay. } \\
\text { I felt sadness by the river, } \\
\text { At the resort I missed the times you were here with me. } \\
\text { The wind is flowing with the river water, } \\
\text { I can't look back on our old love. }\end{array}$ & $\begin{array}{l}\text { suì yuè yōu yōu, } \\
\text { jiù qíng fù shuǐ liú. } \\
\text { yì qù nián jīn rì, } \\
\text { sòng nǐ shàng guī zhōu. } \\
\text { jiāng fēng fú yáng liǔ, } \\
\text { yī rì bú jiàn rú sān qiū. } \\
\text { suì yuè yōu yōu, } \\
\text { jiù qíng bú kě liú. } \\
\text { lín jiāng kōng chóu chàng, } \\
\text { shèng dì yì jiù yóu, } \\
\text { jiāng fêng zhú shuǐ liú, } \\
\text { jiù qíng bú kān zhòng huí shǒu. }\end{array}$ \\
\hline
\end{tabular}


Composer: Jiang Wenye (江文也, 1910-1983)

Title: Shang Chun (伤春, 1939)

Title translation: Sad Spring

Poet: Wang Anshi (王安石, 1021-1085)

\begin{tabular}{|c|c|c|}
\hline $\begin{array}{l}\text { 伤春 } \\
\end{array}$ & Sad Spring & Shāng Chūn \\
\hline $\begin{array}{l}\text { 雨打江南树, } \\
\text { 一夜花开无数。 } \\
\text { 绿叶渐成阴, } \\
\text { 下有游人归路。 } \\
\text { 与君相逢处, } \\
\text { 不道春将暮。 } \\
\text { 把酒祝东风, } \\
\text { 且莫恁、犳物去。 }\end{array}$ & $\begin{array}{l}\text { The rain came down. } \\
\text { Overnight, countless flowers bloomed. } \\
\text { Green leaves gradually created the shade. } \\
\text { Below the trees, many visitors walked home. } \\
\text { Don't you remember that it was the late spring when I met you? } \\
\text { Let's toast to the East wind; } \\
\text { "please continue blowing, don't leave in a hurry. (let the spring } \\
\text { stay)." }\end{array}$ & $\begin{array}{l}\text { yǔ dǎ jiāng nán shù, } \\
\text { yī yè huā kāi wú shù. } \\
\text { lǜ yè jiàn chéng yīn, } \\
\text { xià yǒu yóu rén guî lù. } \\
\text { yǔ jūn xiàng féng chù, } \\
\text { bú dào chūn jiāng mù. } \\
\text { bǎ jiǔ zhù dōng fēng, } \\
\text { qiě mò nín, cōng cōng qù. }\end{array}$ \\
\hline
\end{tabular}


Composer: Lao Zhicheng (老志诚, 1910-2006)

Title: Leifeng Ta Ying (雷锋塔影, 1932)

Title translation: The Shadow of Leifeng Tower

Poet: Xu Zhi Mo (徐志摩, 1903-1987)

\begin{tabular}{|c|c|c|}
\hline 雷锋塔影 & The Shadow of Leifeng Tower & Léifēng Tă Yĩng \\
\hline $\begin{array}{l}\text { 我送你一个雷锋塔影, } \\
\text { 漫天稠密的黑暗与白云。 } \\
\text { 我送你一个雷峰塔顶, } \\
\text { 明月泻影在睡熟的波心。 } \\
\text { 深深的黑夜, } \\
\text { 依依的塔影, } \\
\text { 圆圆的月影, } \\
\text { 纤纤的波麟。 } \\
\text { 啊 } \\
\text { 假如你我当一只无遮的小艇, } \\
\text { 假如你我创造一个完全的梦境。 }\end{array}$ & $\begin{array}{l}\text { I will give you a shadow of Leifeng } \\
\text { Tower. } \\
\text { All over the sky are darkness and } \\
\text { white clouds. } \\
\text { I will give you the top of Leifeng } \\
\text { Tower. } \\
\text { The moon reflects in the center of the } \\
\text { sleeping river. } \\
\text { I see the deep dark night, } \\
\text { the tilt moon shadow, } \\
\text { the slim water waves. } \\
\text { Ah, } \\
\text { If you and I could sail in a small boat, } \\
\text { If you and I could create a complete } \\
\text { dream. }\end{array}$ & $\begin{array}{l}\text { wǒ sòng nǐ yī gè léifēng tă yǐng, } \\
\text { màn tiān chóu mì di hēi àn yǔ bái yún. } \\
\text { wǒ sòng nǐ yī gè léifêng tă dǐng, } \\
\text { míng yuè xiè yǐng zài shuì shú di bō xīn. } \\
\text { shēn shēn di hēi yè, } \\
\text { yî yì di tă yǐng, } \\
\text { yuán yuán di yuè yǐng, } \\
\text { xiān xiān di bō lín. } \\
\text { ā } \\
\text { jiă rú nǐ wǒ dāng yī zhī wú zhē di xiăo } \\
\text { tǐng, } \\
\text { jiă rú nǐ wǒ chuàng zào yī gè wán quán } \\
\text { di mèng jìng. }\end{array}$ \\
\hline
\end{tabular}


Composer: Lin Shengxi (林声翕, 1914-1991)

Title: Bai Yun Gu Xiang (白云故乡,1938)

Title translation: White Cloud and Hometown

Poet: Wei Hanzhang (韦瀚章, 1905-1993)

\begin{tabular}{|c|c|c|}
\hline 白云故乡 & White Cloud and Hometown & Bái Yún Gù Xiāng \\
\hline $\begin{array}{l}\text { 海风翻起白浪, } \\
\text { 浪花贼湿衣裳, } \\
\text { 寂寞的沙滩, } \\
\text { 只有我在凝望, } \\
\text { 群山浮在海上, } \\
\text { 白云躲在山旁, } \\
\text { 层云的后面, } \\
\text { 便是我的故乡。 } \\
\text { 海水茫茫, } \\
\text { 山色苍苍, } \\
\text { 白云依恋在群山的怀里, } \\
\text { 我却望不见故乡, } \\
\text { 我却望不见故乡! } \\
\text { 血沸胸膛, } \\
\text { 仇恨难忘, } \\
\text { 把坚决的信念著称壁垒, } \\
\text { 莫让人侵占故乡, } \\
\text { 莫让人侵占故乡! }\end{array}$ & $\begin{array}{l}\text { The sea breeze turns the white waves, } \\
\text { The wave breaks and splashes on my clothes, } \\
\text { The lonely beach, } \\
\text { It is just me gazing out } \\
\text { The mountains appear to float on the sea, } \\
\text { The white clouds are hidden by the mountain, } \\
\text { Behind the stratus clouds, } \\
\text { is my hometown. } \\
\text { The sea is vast, } \\
\text { The mountains are pale, } \\
\text { The white clouds are attached to the arms of } \\
\text { the mountains, } \\
\text { But I can't see my hometown, } \\
\text { I can't see my hometown! } \\
\text { There is blood boiling in my chest, } \\
\text { The hatred is unforgettable, } \\
\text { Use your strong faith in victory as the barrier } \\
\text { against the invasion, } \\
\text { Do not let people occupy our hometown, } \\
\text { Do not let people occupy our hometown! }\end{array}$ & $\begin{array}{l}\text { hăi fēng fān qǐ bái làng, } \\
\text { làng huā jiàn shī yī shang, } \\
\text { jì mò di shā tān, } \\
\text { zhī yǒu wǒ zài níng wàng, } \\
\text { qún shān fú zài hăi shàng, } \\
\text { bái yún duó zài shān páng, } \\
\text { céng yún di hòu miàn, } \\
\text { biàn shì wǒ di gù xiāng. } \\
\text { hăi shuǐ máng máng, } \\
\text { shān sè cāng cāng, } \\
\text { bái yún yī liàn zài qún shān di huái lǐ, } \\
\text { wǒ què wàng bú jiàn gù xiāng, } \\
\text { wò què wàng bú jiàn gù xiāng! } \\
\text { xuè fèi xiōng táng, } \\
\text { chóu hèn nán wàng, } \\
\text { bǎ jiān jué di xìn niàn zhe chēng bì } \\
\text { lěi, } \\
\text { mò ràng rén qīn zhàn gù xiāng, } \\
\text { mò ràng rén qīn zhàn gù xiāng! }\end{array}$ \\
\hline
\end{tabular}


Composer: Lin Shengxi (林声翕, 1912-2000)

Title: Wang Yun (望云,1938)

Title translation: Watch the Clouds

Poet: Yu Jingshan (余景山, 1916-2004)

\begin{tabular}{|c|c|c|}
\hline 望云 & Watch the Clouds & Wàng Yún \\
\hline $\begin{array}{l}\text { 我欲忘情, } \\
\text { 无奈怎也忘情不了, } \\
\text { 天涯海角, } \\
\text { 伊人宛在梦中微笑。 } \\
\text { 白云故乡, } \\
\text { 如今异国情调。 } \\
\text { 莫说道, } \\
\text { “换你心为我心”, } \\
\text { 却已斡负青春多少。 } \\
\\
\text { 昨宵白浪滔天, } \\
\text { 今日又波平如沼; } \\
\text { 明朝啊, } \\
\text { 何处握手相逢, } \\
\text { 把臂高歌狂跳! }\end{array}$ & $\begin{array}{l}\text { I wanted to forget our love } \\
\text { But I can't forget it. } \\
\text { In the edge of the sky and the sea, } \\
\text { She smiled in my dream. } \\
\text { The white cloud in our hometown, } \\
\text { Now our hometown has become an exotic place. } \\
\text { We used to promise each other in our youth, } \\
\text { 'My heart belongs to your heart," } \\
\text { But we have broken our promise and disappointed our } \\
\text { youth. } \\
\text { Last night the white waves were sky-high, } \\
\text { Today it is quiet again; } \\
\text { When will we hold each other's hands, } \\
\text { wrap our arms around one another, and dance wildly } \\
\text { together? }\end{array}$ & $\begin{array}{l}\text { wǒ yù wàng qíng, } \\
\text { wú nài zěn yě wàng qíng bú le, } \\
\text { tiān yá hăi jiăo, } \\
\text { yī rén wăn zài mèng zhōng wēi xiào. } \\
\text { bái yún gù xiāng, } \\
\text { rú jīn yì guó qíng diào. } \\
\text { mò shuō dào, } \\
\text { "huàn nǐ xīn wéi wǒ xīn", } \\
\text { què yǐ gū fù qīng chūn duō shăo. } \\
\text { zuó xiāo bái làng tāo tiān, } \\
\text { jīn rì yòu bō píng rú zhăo; } \\
\text { míng cháo ā, } \\
\text { hé chù wò shǒu xiàng féng, } \\
\text { bă bì gāo gē kuáng tiào! }\end{array}$ \\
\hline
\end{tabular}


Composer: Li Weining (李惟宁, 1910-1985)

Title: Ou Ran (偶然, 1937)

Title translation: By Chance

Poet: Xu Zhi Mo (徐志摩, 1903-1987)

\begin{tabular}{|c|c|c|}
\hline 偶然 & By Chance & Ǒu Rán \\
\hline $\begin{array}{l}\text { 我是天空里的一片云, } \\
\text { 偶尔投射在你的波心, } \\
\text { 你不必讶异, } \\
\text { 更无须欢喜, } \\
\text { 在转瞬间消灭了踪影。 } \\
\\
\text { 你我相逢在黑夜的海上, } \\
\text { 你有你的我有我的方向； } \\
\text { 你记得也好, } \\
\text { 最好你忘掉 } \\
\text { 在这交会时互放的光亮! }\end{array}$ & $\begin{array}{l}\text { I was a cloud in the sky, } \\
\text { (you were a wave in the sea), } \\
\text { Occasionally, I gazed in to } \\
\text { The center of your wave, } \\
\text { You didn't have to be surprised } \\
\text { and there was no need to rejoice, } \\
\text { because the moment of our meeting } \\
\text { disappeared in an instant. } \\
\text { You and I met in the sea at night, } \\
\text { We were headed in our own different } \\
\text { directions; } \\
\text { Whether or not you can remember our } \\
\text { meeting, } \\
\text { It is best if you can forget the mutual lights } \\
\text { formed then! }\end{array}$ & $\begin{array}{l}\text { wǒ shì tiān kōng lǐ di yī piàn yún, } \\
\text { ǒu ěr tóu shè zài nǐ di bō xīn, } \\
\text { nǐ bú bì yà yì, } \\
\text { gèng wú xū huān xǐ, } \\
\text { zài zhuăn shùn jiān xiāo miè le zōng yǐng. } \\
\text { nǐ wǒ xiàng féng zài hēi yè di hăi shàng, } \\
\text { nǐ yǒu nì di wǒ yǒu wǒ di fāng xiàng; } \\
\text { nǐ jì dé yě hăo, } \\
\text { zuì hăo nǐ wàng diào } \\
\text { zài zhè jiāo huì shí hù fàng di guāng liàng! }\end{array}$ \\
\hline
\end{tabular}


Composer: Liu Xue'an (刘雪庵, 1905-1985)

Title: Piao Ling de Luo Hua (飘零的落花, 1935)

Title translation: The Falling Flowers

Poet: Liu Xue'an (刘雪庵, 1905-1985)

\begin{tabular}{|c|c|c|}
\hline 飘零的落花 & The Falling Flowers & Piāo Líng De Luò Huā \\
\hline $\begin{array}{l}\text { 想当日梢头独占一枝春, } \\
\text { 嫩绿嫣红何等媚人, } \\
\text { 不幸攀折惨遭无情手, } \\
\text { 未随流水转埅风尘。 } \\
\text { 莫怀薄幸惹伤心, } \\
\text { 落花无主任飘零。 } \\
\text { 可怜鸿鱼望断无踪影, } \\
\text { 向谁去鸣咽诉不平。 } \\
\text { 想乍辞枝头别恨新, } \\
\text { 和风和泪舞盈盈。 } \\
\text { 堪叹时人未解侬心苦, } \\
\text { 翻笑红雨落纷纷。 } \\
\text { 愿逐洪流葬此身, } \\
\text { 天涯何处是归程。 } \\
\text { 让玉消相逝无踪影, } \\
\text { 也不求世间予同情。 }\end{array}$ & $\begin{array}{l}\text { On that day, I was the prettiest flower on the top } \\
\text { branch of the tree in the spring. } \\
\text { How beautiful were my colors, the red and green? } \\
\text { Unfortunately, I was crumbled by his merciless } \\
\text { hand? } \\
\text { Then I fell into the dust. } \\
\text { Don't be sad and heartless. } \\
\text { I, as a falling flower, was drifting by with no } \\
\text { purpose. } \\
\text { The merciless Hong bird disappeared without a } \\
\text { trace. } \\
\text { Whom can I complain to? } \\
\text { Don't hate the new flower blooming on the branches } \\
\text { now. } \\
\text { The wind and my tears danced together with me. } \\
\text { People won't be able understand my pitifulness. } \\
\text { They laughed at me in the rain. } \\
\text { I wish to die in the flowing river. } \\
\text { Where will my final journey in this world be? } \\
\text { Let my body disappear without a trace, } \\
\text { I will not beg for any sympathy from this world. }\end{array}$ & $\begin{array}{l}\text { xiăng dāng rì shāo tóu dú zhàn yī zhī } \\
\text { chūn, } \\
\text { nèn lǜ yān hóng hé děng mèi rén, } \\
\text { bú xìng pān shé căn zāo wú qíng } \\
\text { shǒu, } \\
\text { wèi suí liú shuǐ zhuăn duò fēng chén. } \\
\text { mò huái báo xìng rě shāng xīn, } \\
\text { luò huā wú zhǔ rèn piāo líng. } \\
\text { kě lián hóng yú wàng duàn wú zōng } \\
\text { y̌ng, } \\
\text { xiàng shuí qù wū yān sù bú píng. } \\
\text { xiăng zhà cí zhī tóu bié hèn xīn, } \\
\text { hé fêng hé lèi wǔ yíng yíng. } \\
\text { kān tàn shí rén wèi jiè nóng xīn kǔ, } \\
\text { fān xiào hóng yǔ luò fēn fền. } \\
\text { yuàn zhú hóng liú zàng cǐ shēn, } \\
\text { tiān yá hé chù shì guī chéng. } \\
\text { ràng yù xiāo xiàng shì wú zōng yǐng, } \\
\text { yě bú qiú shì jiān yǔ tóng qíng. }\end{array}$ \\
\hline
\end{tabular}


Composer: Liu Xue'an (刘雪庵, 1905-1985)

Title: Chang Cheng Yao (长城谣, 1937)

Title translation: The Ballad of the Great Wall

Poet: Pan jienong (潘子农, 1909-1993)

\begin{tabular}{|c|c|c|}
\hline 长城谣 & The Ballad of the Great Wall & Cháng Chéng Yáo \\
\hline $\begin{array}{l}\text { 万里长城万里长, } \\
\text { 长城外面是故乡, } \\
\text { 高粱肥, 大豆香, } \\
\text { 遍地黄金少灾殊。 } \\
\text { 自从大难平地起, } \\
\text { 奸淫掳掠苦难当, } \\
\text { 苦难当,奔他方, } \\
\text { 骨肉流散父母丧. } \\
\text { 没齿难忘仇和恨, } \\
\text { 日夜只想回故乡, } \\
\text { 大家拼命打回去, } \\
\text { 哪怕倭奴逞豪强. } \\
\text { 万里长城万里长, } \\
\text { 长城外面是故乡 } \\
\text { 四万万同胞心一样, } \\
\text { 新的长城万里长. }\end{array}$ & $\begin{array}{l}\text { The Great Wall is ten thousand miles long, } \\
\text { Outside the Great Wall is our hometown, } \\
\text { The Sorghum grew with fertilizer. } \\
\text { When the soybean grew, it smelled good. } \\
\text { The farm was our gold, } \\
\text { there was no disaster. } \\
\text { When the war started, } \\
\text { the war crimes burdened us with misery. } \\
\text { We had to escape somewhere else, } \\
\text { families were broken up and children lost their } \\
\text { parents. } \\
\text { I won't ever forget this. } \\
\text { Day and night, } \\
\text { we just want to go back to our hometown. } \\
\text { Let's protect our homeland, } \\
\text { no matter how strong our enemy is. } \\
\text { The Great Wall is ten thousand miles long, } \\
\text { Outside the Great Wall is our hometown. } \\
\text { Forty thousand peoples' hearts are filled with } \\
\text { longing to return to their hometown. } \\
\text { The new great wall is ten thousand miles long. }\end{array}$ & $\begin{array}{l}\text { wàn lǐ cháng chéng wàn lǐ zhăng, } \\
\text { zhăng chéng wài miàn shì gù xiāng, } \\
\text { gāo liáng féi, dà dòu xiāng, } \\
\text { biàn dì huáng jīn shăo zāi yāng. } \\
\text { zì cóng dà nán píng dì qǐ, } \\
\text { jiān yín lǔ luě kǔ nán dāng, } \\
\text { kǔ nán dāng,bēn tā fāng, } \\
\text { gǔ ròu liú sàn fù mǔ sàng。 } \\
\text { méi chǐ nán wàng chóu hé hèn, } \\
\text { rì yè zhī xiăng huí gù xiāng, } \\
\text { dà jiā pīn mìng dǎ huí qù, } \\
\text { nă pà wō nú chěng háo qiáng } \\
\text { wàn lǐ zhăng chéng wàn lǐ zhăng, } \\
\text { zhăng chéng wài miàn shì gù xiāng } \\
\text { sì wàn wàn tóng bāo xīn yī yàng, } \\
\text { xīn di zhăng chéng wàn lǐ zhăng。 }\end{array}$ \\
\hline
\end{tabular}


Composer: Liu Xue'an (刘雪庵, 1905-1985)

Title: Zhui Xun (追寻, 1938)

Title translation: The Pursuit

Poet: Xu Jianwu (许建吾, 1903-1987)

\begin{tabular}{|c|c|c|}
\hline 追寻 & The Pursuit & Zhuī Xún \\
\hline $\begin{array}{l}\text { 你是晴空的流云, } \\
\text { 你是子夜的流星。 } \\
\text { 一片深情, } \\
\text { 紧紧封锁着我的 } \\
\text { 心。 } \\
\text { 一线光明, } \\
\text { 时时照耀着我的 } \\
\text { 心。 } \\
\text { 我哪能忍得住呦! } \\
\text { 我哪能再等待呦! } \\
\text { 我要追寻, } \\
\text { 追寻那无尽的深情, } \\
\text { 追寻那永远的光 } \\
\text { 明。 }\end{array}$ & $\begin{array}{l}\text { You are a floating cloud in the sunny sky. } \\
\text { You are the meteor in the mighty night sky. } \\
\text { Our love is so full that it fills my heart completely. } \\
\text { The light shines in my heart all the time. } \\
\text { I can't bear it anymore! } \\
\text { I can't wait anymore! } \\
\text { I need to pursue; } \\
\text { pursue the never ending love, } \\
\text { pursue the forever light. }\end{array}$ & $\begin{array}{l}\text { nǐ shì qíng kōng di liú yún, } \\
\text { nǐ shì zǐ yè di liú xīng. } \\
\text { yī piàn shēn qíng, } \\
\text { jǐn jǐn fēng suǒ zhe wǒ di xīn. } \\
\text { yī xiàn guāng míng, } \\
\text { shí shí zhào yào zhe wǒ di xīn. } \\
\text { wǒ nă néng rěn dé zhù yōu! } \\
\text { wǒ nă néng zài děng dài yōu! } \\
\text { wǒ yào zhuī xún, } \\
\text { zhuī xún nà wú jìn di shēn qíng, } \\
\text { zhuī xún nà yǒng yuăn di guāng míng. }\end{array}$ \\
\hline
\end{tabular}


Composer: Lu Huabai (陆华柏, 1914-1994)

Title: Gu Xiang (故乡,1937)

Title translation: Hometown

Poet: Zhang Anzhi (张安治, 1911-1990)

\begin{tabular}{|c|c|c|}
\hline 故乡 & Hometown & Gù Xiāng \\
\hline $\begin{array}{l}\text { 故乡! } \\
\text { 我生长的地方, } \\
\text { 本来是一个天堂。 } \\
\text { 那儿有清澈的河流, } \\
\text { 垂杨夹岸; } \\
\text { 那儿有茂密的松林, } \\
\text { 在那小小的山冈。 } \\
\text { 春天新绿的草原有牛羊来往, } \\
\text { 秋天的丛树灿烂辉煌。 } \\
\text { 月夜我们曾泛舟湖上, } \\
\text { 在那庄严的古庙, } \\
\text { 几次凭吊斜现, } \\
\text { 现在一切都改变了! } \\
\text { 现在已经是野兽的屠场! }\end{array}$ & $\begin{array}{l}\text { Hometown! } \\
\text { The place where I grew up } \\
\text { was originally a paradise. } \\
\text { There were clear rivers and } \\
\text { poplar trees on the sides of the river. } \\
\text { There was a dense pine forest } \\
\text { on that little hill. } \\
\text { There were cows and sheep in the fresh green } \\
\text { grassland in the spring. } \\
\text { The bushes were brilliant in autumn. } \\
\text { On the moonlit night we once rafted on the } \\
\text { lake. } \\
\text { We gazed out at the world from inside the } \\
\text { stately old temple many times. } \\
\text { Now everything has changed! } \\
\text { Our hometown is now the slaughterhouse of } \\
\text { the beast! }\end{array}$ & $\begin{array}{l}\text { gù xiāng! } \\
\text { wǒ shēng zhăng di dì fāng, } \\
\text { běn lái shì yī gè tiān táng } \\
\text { nàr yǒu qīng chè di hé liú, } \\
\text { chuí yáng jiá àn; } \\
\text { nàr yǒu mào mì di sōng lín, } \\
\text { zài nà xiăo xiăo di shān gāng } \\
\text { chūn tiān xīn lù di căo yuán yǒu } \\
\text { niú yáng lái wăng, } \\
\text { qiū tiān di cóng shù càn làn huī } \\
\text { huáng } \\
\text { yuè yè wǒ men céng fàn zhōu hú } \\
\text { shàng, } \\
\text { zài nà zhuāng yán di gǔ miào, } \\
\text { jì cì píng diào xié xiàn, } \\
\text { xiàn zài yī qiē dōu găi biàn le! } \\
\text { xiàn zài yî jīng shì yě shòu di tú } \\
\text { chăng! }\end{array}$ \\
\hline
\end{tabular}


Composer: Lu Huabai (陆华柏, 1914-1994)

Title: Yong Shi Gu (勇士骨,1938)

Title translation: The Warriors' Bones

Poet: Hu Ran (胡然, 1911-1990)

\begin{tabular}{|c|c|c|}
\hline 勇士骨 & The Warriors' Bones & Yǒng Shì Gǔ \\
\hline $\begin{array}{l}\text { 这原野啊! } \\
\text { 曾流遍了英雄的血, } \\
\text { 多少战士为祖国作了光荣地 } \\
\text { 牺牲, } \\
\text { 和敌人一同倒卧在战场上。 }\end{array}$ & $\begin{array}{l}\text { This field! } \\
\text { It once flowed with the heroes' blood. } \\
\text { How many soldiers made glorious sacrifices } \\
\text { for the motherland? } \\
\text { They lie on the battlefield together with the } \\
\text { enemy. }\end{array}$ & $\begin{array}{l}\text { zhè yuán yě a! } \\
\text { céng liú biàn le yīng xióng di xuè, } \\
\text { duō shăo zhàn shì wéi zǔ guó zuò le } \\
\text { guāng róng dì xī shēng, } \\
\text { hé dí rén yī tóng dăo wò zài zhàn } \\
\text { chăng shàng. }\end{array}$ \\
\hline $\begin{array}{l}\text { 炮火已经息了, } \\
\text { 现在是一片死的原野, } \\
\text { 只有西风在那里哭泣, } \\
\text { 在那里凭吊。 }\end{array}$ & $\begin{array}{l}\text { The artillery is over. } \\
\text { Now there is a field full of the dead. } \\
\text { And only the westerly wind was left to cry for } \\
\text { them. }\end{array}$ & $\begin{array}{l}\text { pào huǒ yǐ jīng xī le, } \\
\text { xiàn zài shì yī piàn sǐ di yuán yě, } \\
\text { zhī yǒu xī fēng zài nà lǐ kū qì, } \\
\text { zài nà lǐ píng diào. }\end{array}$ \\
\hline $\begin{array}{l}\text { 红叶轻轻地抚着白骨, } \\
\text { “战士, } \\
\text { 你还躺在这里做什么?” } \\
\text { “我吗?” } \\
\text { 他安静地回答: } \\
\text { “我在等待最后胜利的消息”. }\end{array}$ & $\begin{array}{l}\text { The red leaves gently touched the bones and } \\
\text { asked; "Warrior, what are you doing here?" } \\
\text { "Me?" He answered quietly, } \\
\text { "I am waiting for the news of our final } \\
\text { victory." }\end{array}$ & $\begin{array}{l}\text { hóng yè qīng qīng dì fǔ zhe bái gǔ, } \\
\text { "zhàn shì, } \\
\text { nǐ hái tăng zài zhè lǐ zuò shí me?" } \\
\text { "wǒ ma?" } \\
\text { tā ān jìng dì huí dá : } \\
\text { "wǒ zài děng dài zuì hòu shèng lì di } \\
\text { xiāo xī". }\end{array}$ \\
\hline
\end{tabular}


Composer: Nie Er (聂耳, 1921-1935)

Piano arrangement: Chen Yixin (陈贻金金, 1926-)

Title: Gao Bie Nan Yang (告别南洋, 1934)

Title translation: Farewell to South Asia

Poet: Tian Han (田汉, 1898-1968)

\begin{tabular}{|c|c|c|}
\hline 告别南洋 & Farewell to South Asia & Gào Bié Nán Yáng \\
\hline $\begin{array}{l}\text { 再会吧,南洋! } \\
\text { 你海波绿, } \\
\text { 海云长, } \\
\text { 你是我们第二个故乡; } \\
\text { 我们民族的血汗, } \\
\text { 滴遍了这几百个荒凉的岛上。 } \\
\text { 再会吧,南洋! } \\
\text { 你椰子肥, } \\
\text { 豆蔻香, } \\
\text { 你受着自然的丰实的供养; } \\
\text { 但在帝国主义的剥削下, } \\
\text { 千百万被压迫者都闹着饥荒。 } \\
\text { 再会吧,南洋! } \\
\text { 你不见尸横着长白山, } \\
\text { 血流着黑龙江? } \\
\text { 这是中华民族的存亡! } \\
\\
\text { 再会吧,南洋! } \\
\text { 我们要去争取一线光明的希望! }\end{array}$ & $\begin{array}{l}\text { Goodbye to South Asia! } \\
\text { Your sea waves are green, } \\
\text { your sea clouds are long. } \\
\text { You are our second hometown. } \\
\text { The blood and sweat of our nation are } \\
\text { dripping all over these hundreds of } \\
\text { desolate islands. } \\
\text { Goodbye, South Asia! } \\
\text { Your coconuts grow large. } \\
\text { Your cardamom smells great. } \\
\text { Your nutritious environment is productive } \\
\text { and fruitful. } \\
\text { But under the exploitation of imperialism, } \\
\text { millions of oppressed are starving. } \\
\text { Goodbye, South Asia! } \\
\text { You do not see the corpses laying under } \\
\text { Changbai Mountain. } \\
\text { Blood is flowing in Heilong River? } \\
\text { This is the state of our nation! } \\
\text { Goodbye, South Asia! } \\
\text { We are going to fight for a glimmer of } \\
\text { hope! }\end{array}$ & $\begin{array}{l}\text { zài huì ba, nán yang! } \\
\text { nǐ hăi bō lü, } \\
\text { hăi yún zhăng, } \\
\text { nǐ shì wǒ men dì èr gè gù xiāng; } \\
\text { wǒ men mín zú di xuè hàn, } \\
\text { dī biàn le zhè jǐ băi gè huāng liáng di } \\
\text { dǎo shàng. } \\
\text { zài huì ba, nán yang! } \\
\text { nǐ yē zǐ féi, } \\
\text { dòu kòu xiāng, } \\
\text { nǐ shòu zhe zì rán di fēng shí di gòng } \\
\text { yang; } \\
\text { dàn zài dì guó zhǔ yì de bāo xuē xià, } \\
\text { qiān băi wàn bèi yā pò zhě dōu nào zhe } \\
\text { jī huāng. } \\
\text { Zài huì ba, nán yang! } \\
\text { nǐ bú jiàn shī héng zhe zhăng bái shān, } \\
\text { xuè liú zhe hēi lóng jiāng? } \\
\text { zhè shì zhōng huá mín zú di cún wáng! } \\
\text { zài huì ba, nán yáng! } \\
\text { wó men yào qù zhēng qǔ yī xiàn guāng } \\
\text { míng di xī wàng! }\end{array}$ \\
\hline
\end{tabular}


Composer：Nie Er (聂耳, 1921-1935)

Piano arrangement: Song Chengxian (宋承宪)

Title: Meiniang Qu (梅娘曲, 1934)

Title translation: Song of Meiniang

Poet: Tian Han (田汉, 1898-1968)

\begin{tabular}{|c|c|c|}
\hline 梅娘曲 & Song of Meiniang & Méiniáng Qū \\
\hline $\begin{array}{l}\text { 哥哥,你别忘了我呀, } \\
\text { 我是你亲爱的梅娘, } \\
\text { 你曾坐在我们家的窗上, } \\
\text { 嚼着那鲜红的槟榔, } \\
\text { 我曾轻弹着吉他, } \\
\text { 为你慢声儿歌唱, } \\
\text { 当我们在遥远的南洋。 } \\
\text { 哥哥,你别忘了我呀, } \\
\text { 我是你亲爱的梅娘, } \\
\text { 你曾坐在红河的岸旁, } \\
\text { 我们祖宗流血的地方, } \\
\text { 送我们的勇士还乡, } \\
\text { 我不能和你同来, } \\
\text { 我是那样的惆怅。 } \\
\text { 哥哥,你别忘了我呀, } \\
\text { 我是你亲爱的梅娘, } \\
\text { 我为你违背了昘娘, } \\
\text { 离开那遥远的南洋, } \\
\text { 我预备用我的眼泪, } \\
\text { 搽好你的创伤, } \\
\text { 但是,但是, } \\
\text { 你已经不认得我了, } \\
\text { 你的可怜的梅娘。 }\end{array}$ & $\begin{array}{l}\text { My lover, don't forget me. } \\
\text { I am your dear Meiniang. } \\
\text { You sat on the window of our house, chewing the } \\
\text { bright red betel nut. } \\
\text { I used to strum the guitar, } \\
\text { and sing slowly for you. } \\
\text { When we were in the far South Asia. } \\
\text { My lover, don't forget me. } \\
\text { I am your dear Meiniang. } \\
\text { You were sitting on the shore of the Red River, } \\
\text { where our ancestors bled. } \\
\text { I asked them to send our warriors back home. } \\
\text { I couldn't come with you. } \\
\text { I'm so sad. } \\
\text { My lover, don't forget me. } \\
\text { I am your dear Meiniang. } \\
\text { I left my father and mother for you and left that } \\
\text { distant South Asia. } \\
\text { I am going to use my tears to } \\
\text { heal your wounds. } \\
\text { However, however, } \\
\text { You don't recognize me anymore. } \\
\text { Your poor Meiniang. }\end{array}$ & $\begin{array}{l}\text { gē gē, nǐ bié wàng liao wǒ ya, } \\
\text { wǒ shì nǐ qīn ài di méi niáng, } \\
\text { nǐ céng zuò zài wǒ men jiā di chuāng } \\
\text { shàng, } \\
\text { jiáo zhe nà xiān hóng di bīn láng, } \\
\text { wó céng qīng dàn zhe jí tā, } \\
\text { wéi nǐ màn sheng er gē chàng, } \\
\text { dāng wó men zài yáo yuăn di nán } \\
\text { yang. } \\
\text { gē gē, nǐ bié wàng le wǒ ya, } \\
\text { wǒ shì nǐ qīn ài di méi niáng, } \\
\text { nǐ céng zuò zài hóng hé di àn pang, } \\
\text { wǒ men zǔ zōng liú xuè di dì fang, } \\
\text { sòng wó men di yǒng shì hái xiāng, } \\
\text { wǒ bú néng hé nǐ tóng lái, } \\
\text { wǒ shì nà yàng di chóu chàng. } \\
\text { gē gē, nǐ bié wàng le wǒ ya, } \\
\text { wǒ shì nǐ qīn ài di méi niáng, } \\
\text { wǒ wéi nǐ wéi bèi le diē niáng, } \\
\text { lí kāi nà yáo yuăn di nán yang, } \\
\text { wǒ yù bèi yòng wǒ di yăn lèi, } \\
\text { chá hăo nǐ di chuàng shāng, } \\
\text { dàn shì, dàn shì, } \\
\text { nǐ y̌̌ jīng bú rèn dé wǒ liao, } \\
\text { nǐ di kě lian di méi niáng. }\end{array}$ \\
\hline
\end{tabular}


Composer: Nie $\operatorname{Er}$ (聂耳, 1921-1935)

Piano arrangement: Qu Xixian (㫿希贤, 1919-2008)

Title: Tie Ti Xia de Ge Nv (铁蹄下的歌女, 1935)

Title translation: The Singing Women under the Iron Hoof

Poet: Xu Xing Zhi (许幸之, 1904-1991)

\begin{tabular}{|c|c|c|}
\hline 铁蹄下的歌女 & The Singing Women under the Iron Hoof & Tiě Tí Xià Dí Gē Nü \\
\hline $\begin{array}{l}\text { 我们到处卖唱, } \\
\text { 我们到处献舞, } \\
\text { 谁不知道国家将亡, } \\
\text { 为什么被人当作商女? } \\
\text { 为了饥寒交迫,我们到处哀歌, } \\
\text { 尝尽了人生的滋味, } \\
\text { 舞女是永远的漂流, } \\
\\
\text { 谁甘心做人的奴隶, } \\
\text { 谁愿意让乡土沦丧? } \\
\text { 可怜是铁蹄下的歌女, } \\
\text { 被楩挞的遍体鳞伤! }\end{array}$ & $\begin{array}{l}\text { Everywhere, we sing to live our lives. } \\
\text { Everywhere, we dance to live our lives. } \\
\text { Doesn't everyone know that the country is } \\
\text { about to die? } \\
\text { Why are people treating us as showgirls? } \\
\text { Because of the hunger and cold, we are } \\
\text { lamenting everywhere. } \\
\text { We have tasted the bitterness of life. } \\
\text { The showgirls are homeless forever. } \\
\text { Who is willing to be a slave? } \\
\text { Who wants to lose our country? } \\
\text { The showgirls are poor, under the iron hoof. } \\
\text { They were whipped all over their bodies! }\end{array}$ & $\begin{array}{l}\text { wǒ men dào chù mài chàng, } \\
\text { wǒ men dào chù xiàn wǔ, } \\
\text { shuí bú zhī dào guó jiā jiāng wáng, } \\
\text { wéi shén me bèi rén dāng zuò shāng } \\
\text { nǔ́? } \\
\text { wéi le jī hán jiāo pò, wǒ men dào } \\
\text { chù āi gē, } \\
\text { cháng jìn le rén shēng di zī wèi, } \\
\text { wǔ nü shì yǒng yuăn di piāo liú, } \\
\text { shuí gān xīn zuò rén di nú lì, } \\
\text { shuí yuàn yì ràng xiāng tǔ lún sàng? } \\
\text { kě lián shì tiě tí xià di gē nŭ́, } \\
\text { bèi biān tǎ di biàn tǐ lín shāng! }\end{array}$ \\
\hline
\end{tabular}


Composer: Ren Guang (任光, 1990-1941)

Piano Arrangement: Cheng Yixin (陈贻金金, 1926-)

Title: Yu Guangqu (渔光曲, 1934)

Title translation: Fisherman's Song

Poet: An E (安娥, 1905-1976)

\begin{tabular}{|c|c|c|}
\hline 渔光曲 & Fisherman's Song & Yú Guāng Qū \\
\hline $\begin{array}{l}\text { 云儿飘在海空, } \\
\text { 鱼儿藏在水中。 } \\
\text { 早晨太阳里晒鱼网, } \\
\text { 迎面吹过来大海风。 } \\
\text { 潮水升,浪花涌, } \\
\text { 渔船儿飘飘各西东。 } \\
\text { 轻撒网,紧拉绳, } \\
\text { 烟雾里辛苦等鱼踪。 } \\
\text { 鱼儿难捕船租重, } \\
\text { 捕鱼人地穷。 } \\
\text { 爷爷留下的破鱼网, } \\
\text { 小心再靠它过一冬。 } \\
\text { 东方现出微明, } \\
\text { 星儿藏入天空。 } \\
\text { 早晨渔船儿返回程, } \\
\text { 迎面吹过来送潮风。 } \\
\text { 天已明,力已尽, } \\
\text { 眼望着渔村路万重。 } \\
\text { 腰已酸,手也肿, } \\
\text { 捕得了鱼儿腹内空。 } \\
\text { 鱼儿捕得不满筐, } \\
\text { 又是东方太阳红。 } \\
\text { 爷爷留下的破鱼网, } \\
\text { 小心还靠它过一冬。 }\end{array}$ & $\begin{array}{l}\text { The cloud was floating on the sky. } \\
\text { The fish was hiding under the water. } \\
\text { There were fishnets in the morning sun. } \\
\text { The sea breeze blew over my face. } \\
\text { The tide rose, the waves surged, } \\
\text { The fishing boat flew to the west and the east. } \\
\text { I gently spread the net. I tightly pulled the rope. } \\
\text { I waited for any fish to appear in the smoky mist. } \\
\text { It's hard to catch a fish. } \\
\text { A boat's rent is very expensive. } \\
\text { Fishermen are poor throughout generations. } \\
\text { The broken fishnet was left to me by my grandpa. } \\
\text { I need to be careful with it so that I can rely on it for } \\
\text { another winter. } \\
\text { The moonlight appears in the East. } \\
\text { The stars hide in the sky. } \\
\text { The fishing boat from the morning is returning. } \\
\text { The sea breeze blows over my face. } \\
\text { The sky is clear, and my energy is exhausted. } \\
\text { I gaze towards my town. } \\
\text { There is a long way to go to get back to my town. } \\
\text { My waist is sore, and my hands are swollen. } \\
\text { I caught fish, but I still have to starve. } \\
\text { I didn't catch many fish. } \\
\text { The eastern sun is red again. } \\
\text { The broken fishnet was left to me by my grandpa. } \\
\text { I need to be careful with it so that I can rely on it for } \\
\text { another winter. }\end{array}$ & $\begin{array}{l}\text { yún er piāo zài hăi kōng, } \\
\text { yú er cáng zài shuǐ zhōng. } \\
\text { zăo chén tài yáng lǐ shài yú wăng, } \\
\text { yíng miàn chuī guò lái dà hăi fēng. } \\
\text { cháo shuǐ sheng, làng huā yǒng, } \\
\text { yú chuán er piāo piāo gè xī dōng. } \\
\text { qīng sā wăng, jīn lā sheng, } \\
\text { yān wù lǐ xīn kǔ děng yú zōng. } \\
\text { yú er nán bǔ chuán zū zhòng, } \\
\text { bǔ yú rén er shì shì qióng. } \\
\text { yé yé liú xià di pò yú wăng, } \\
\text { xiăo xīn zài kào tā guò yī dōng. } \\
\text { dōng fāng xiàn chū wēi míng, } \\
\text { xīng er cáng rù tiān kōng. } \\
\text { zăo chén yú chuán er făn huí chéng, } \\
\text { yíng miàn chuī guò lái sòng cháo } \\
\text { fēng. } \\
\text { tiān yì míng, lì yǐ jìn, } \\
\text { yăn wàng zhe yú cūn lù wàn zhòng. } \\
\text { yāo yǐ suān, shǒu yě zhǒng, } \\
\text { bǔ dé le yú er fù nèi kōng. } \\
\text { yú er bǔ dé bú măn kuāng. } \\
\text { yòu shì dōng fāng tài yáng hóng. } \\
\text { yé yé liú xià di pò yú wăng, } \\
\text { xiăo xīn hái kào tā guò yī dōng. }\end{array}$ \\
\hline
\end{tabular}


Composer: Sha Mei (沙梅, 1909-)

Title: Da Chai Ge (打柴歌, 1930s)

Title translation: Chopping Wood Song

Poet: Chen Zizhan (陈子展, 1998-1990)

\begin{tabular}{|c|c|c|}
\hline 打柴歌 & Chopping Wood Song & Dă Chái Gē \\
\hline $\begin{array}{l}\text { 八十岁公公打藜蒿 } \\
\text { 哦喂哟哦喂, } \\
\text { 头发胡子白飘飘 } \\
\text { 哦呀儿哟哦喂哟哦喂, } \\
\text { 你看我拿着弯刀, } \\
\text { 挑着扁担, } \\
\text { 逢山过了坳, } \\
\text { 逢水过了桥, } \\
\text { 山高哪怕有虎豹, } \\
\text { 水深哪怕有龙蛟哦喂。 } \\
\text { 逢热脱了袄, } \\
\text { 逢冷穿了袍, } \\
\text { 热天哪怕阳光烤, } \\
\text { 冷天哪怕北风号哦喂。 } \\
\text { 我一天不打要柴烧呀儿哟哦 } \\
\text { 喂, } \\
\text { 八十岁公公打藜蒿 } \\
\text { 八哦呀儿哟哦喂, } \\
\text { 呦嗬喂, } \\
\text { 哟哦喂哟哦喂。 }\end{array}$ & $\begin{array}{l}\text { 80-year-old grandpa was cutting down some } \\
\text { Artemisia. } \\
\text { "Oh wei. You, oh wei." } \\
\text { His white hair and mustache were floating in } \\
\text { the wind. } \\
\text { "Oh ya er. You, oh wei. You, oh wei." } \\
\text { You looked at me while I was holding a sickle } \\
\text { and carrying a shoulder pole. } \\
\text { I crossed the low valley in the mountains. } \\
\text { I crossed over the bridge and looked at the } \\
\text { water underneath it. } \\
\text { If the mountain is high, there won't be any } \\
\text { tigers or jaguars. } \\
\text { If the water is deep, there won't be any } \\
\text { dragons. } \\
\text { If the weather is hot, we will take off our } \\
\text { coats. } \\
\text { If the weather is cold, we will put on our } \\
\text { coats. } \\
\text { During hot days, we won't be afraid of the hot } \\
\text { sun. } \\
\text { During cold days, we won't be afraid of the } \\
\text { north wind. } \\
\text { I won't stop chopping wood even for one day. } \\
80 \text {-year-old grandpa was cutting down some } \\
\text { Artemisia. } \\
\text { "Oh wei. You, oh wei." }\end{array}$ & $\begin{array}{l}\text { bā shí suì gōng gōng dă lí hāo } \\
\text { o wèi yō o wèi, } \\
\text { tóu fā hú zǐ bái piāo piāo } \\
\text { o ya er yō o wèi yō o wèi, } \\
\text { nǐ kàn wǒ ná zhe wān dāo, } \\
\text { tiāo zhe biăn dān, } \\
\text { féng shān guò le ào, } \\
\text { féng shuǐ guo le qiáo, } \\
\text { shān gāo nă pà yôu hŭ bào, } \\
\text { shuǐ shēn nă pà yǒu lóng jiāo wèi. } \\
\text { féng rè tuō le ǎo, } \\
\text { féng lěng chuān le páo, } \\
\text { rè tiān nă pà yáng guāng kăo, } \\
\text { lěng tiān nă pà běi fēng háo o wèi. } \\
\text { wǒ yī tiān bú dă yào chái shāo ya er } \\
\text { yō o wèi, } \\
\text { bā shí suì gōng gōng dă lí hāo } \\
\text { o ya er yōo oèi, } \\
\text { yōu he wèi, } \\
\text { yō o wèi yō o wèi. }\end{array}$ \\
\hline
\end{tabular}


Composer: Wang Luobin (王洛宾, 1913-1996)

Piano Arrangement: Zhang Yan'ni (张彦妮)

Title: Zai Na Yao Yuan de Di Fang (在那遥远的地方, 1939)

Title translation: At That Distant Place

\begin{tabular}{|c|c|c|}
\hline 在那遥远的地方 & At That Distant Place & Zài Nà Yáo Yuăn de Dì Fāng \\
\hline $\begin{array}{l}\text { 在那遥远的地方 } \\
\text { 有位好姑娘, } \\
\text { 人们走过了她的帐房 } \\
\text { 都要回头留恋地张望。 } \\
\text { 我愿抛弃了财产跟她去放羊, } \\
\text { 每天看着她粉红的笑脸 } \\
\text { 和那美丽金边的衣裳。 } \\
\text { 我愿做一只小羊 } \\
\text { 坐在她身旁, } \\
\text { 我愿她拿着细细的皮鞭 } \\
\text { 不断轻轻打在我身上。 }\end{array}$ & $\begin{array}{l}\text { In that distant place, } \\
\text { there is a beautiful shepherd girl. } \\
\text { Anyone who has ever walked past her } \\
\text { tent, } \\
\text { can't help but look back at her again and } \\
\text { again. } \\
\text { I am willing to abandon my belongings } \\
\text { in order to be with her. } \\
\text { I want to be a shepherd with her, so that I } \\
\text { can look into her smiling pink face and at } \\
\text { her beautiful golden clothes every day. } \\
\text { I would like to be a lamb } \\
\text { sitting beside her. } \\
\text { I wish she would use her thin leather } \\
\text { whip to keep hitting me gently. }\end{array}$ & $\begin{array}{l}\text { zài nà yáo yuăn di dì fāng } \\
\text { yóu wèi hăo gū niáng, } \\
\text { rén men zǒu guò le tā di zhàng fáng } \\
\text { dōu yào huí tóu liú liàn dì zhāng wàng. } \\
\text { wǒ yuàn pāo qì le cái chăn gēn tā qù fàng } \\
\text { yáng, } \\
\text { měi tiān kàn zhe tā fěn hóng di xiào liăn } \\
\text { hé nà měi lì jīn biān di yī shang. }\end{array}$ \\
\hline
\end{tabular}


Composer: Xia Zhiqiu (夏之秋, 1912-1993)

Title: Si Xiang Qu (思乡曲, 1939)

Title translation: The Song of Homesickness

Poet: Dai Tiandao (戴天道, 1904-1991)

\begin{tabular}{|c|c|c|}
\hline 思乡曲 & The Song of Homesickness & Sī Xiāng Qǔ \\
\hline $\begin{array}{l}\text { 月儿高挂在天上, } \\
\text { 光明照耀四方, } \\
\text { 在这个静静的深夜里, } \\
\text { 记起了我的故乡。 } \\
\text { 一夜里炮声高涨, } \\
\text { 火光布满四方, } \\
\text { 我独自逃出了敌人手, } \\
\text { 到如今东西流浪。 } \\
\text { 故乡远隔在重洋, } \\
\text { 旦夕不能相忘, } \\
\text { 那儿有我高年的苦命娘, } \\
\text { 盼望着游子返乡。 } \\
\text { 月儿高挂在天上, } \\
\text { 光明照耀四方, } \\
\text { 在这个静静的深夜里, } \\
\text { 记起了我的故乡. }\end{array}$ & $\begin{array}{l}\text { The moon hangs high up in the sky. } \\
\text { Light is shining in every direction. } \\
\text { In this quiet late night, } \\
\text { I remember my hometown on a night long ago. } \\
\text { The sound of gunfire rose overnight, } \\
\text { and firelight covered the sky in every direction. } \\
\text { I escaped from the enemy, } \\
\text { and now I'm fleeing everywhere. } \\
\text { My hometown is far away over the sea, } \\
\text { I can't forget it during the day or night. } \\
\text { My old mother is living a bitter life there. } \\
\text { She is looking forward to my return. } \\
\text { The moon hangs high up in the sky. } \\
\text { Light is shining in every direction. } \\
\text { In this quiet late night, } \\
\text { I remember my hometown on a night long ago. }\end{array}$ & $\begin{array}{l}\text { yuè er gāo guà zài tiān shàng, } \\
\text { guāng míng zhào yào sì fāng, } \\
\text { zài zhè gè jìng jìng di shēn yè lǐ, } \\
\text { jì qî le wǒ di gù xiāng. } \\
\text { yĩ yè lǐ pào shēng gāo zhăng, } \\
\text { huǒ guāng bù măn sì fāng, } \\
\text { wǒ dú zì táo chū le dí rén shǒu, } \\
\text { dào rú jīn dōng xī liú làng. } \\
\text { gù xiāng yuăn gé zài zhòng yáng, } \\
\text { dàn xī bú néng xiàng wàng, } \\
\text { nà er yǒu wǒ gāo nián di kǔ mìng } \\
\text { niáng, } \\
\text { pàn wàng zhe yóu zĩ fãn xiāng. } \\
\text { yuè er gāo guà zài tiān shàng } \\
\text { guāng míng zhào yào sì fāng } \\
\text { zài zhè gè jìng jìng di shēn yè lǐ } \\
\text { jì qî le wǒ di gù xiāng }\end{array}$ \\
\hline
\end{tabular}


Composer: Xian Xing Hai (冼星海, 1905-1945)

Title: Ye Ban Ge Sheng (夜半歌声, 1937)

Title Translation: Singing at Midnight

Poet: Tian Han (田汉, 1898-1968)

\begin{tabular}{|c|c|c|}
\hline 夜半歌声 & Singing at Midnight & Yè Bàn Gē Shēng \\
\hline $\begin{array}{l}\text { 空庭飞着流萤, } \\
\text { 高台走着狸鼠, } \\
\text { 人儿伴着孤灯, } \\
\text { 梆儿敲着三更, } \\
\text { 风凄凄,雨淋淋, } \\
\text { 花乱落,叶飘零。 } \\
\text { 在这漫漫的黑夜里谁同我等待着 } \\
\text { 天明? } \\
\text { 我形儿是鬼似的狰狞, } \\
\text { 心儿是铁似的坚贞。 } \\
\text { 我只要一息尚存, } \\
\text { 誓和那封建的魔王抗争。 }\end{array}$ & $\begin{array}{l}\text { Fireflies are flying around the empty patio. } \\
\text { A racoon is walking on the high wall. } \\
\text { I am with the lonely lights. } \\
\text { The midnight is drawing near. } \\
\text { The wind is blowing, the rain is dripping, } \\
\text { the flowers are scattered, and the leaves are } \\
\text { falling. } \\
\text { Who is waiting with me for the sunrise } \\
\text { tonight? } \\
\text { My body looks like a distorted ghost. } \\
\text { My heart is as strong as iron. } \\
\text { If only I had one breath left, } \\
\text { I would make an oath to fight the demon } \\
\text { king. } \\
\text { Ah, my girl, } \\
\text { Only your eyes can understand my life. } \\
\text { Only you can understand my heartfelt } \\
\text { emotions! } \\
\text { You are the moon in the sky, } \\
\text { I am the cold star by the moon! } \\
\text { You are the tree on the mountain, } \\
\text { I am the dead branch on the tree! } \\
\text { You are the water in the pond, } \\
\text { I am the floating duckweed on the water! } \\
\text { No, my girl, I would rather be buried in the } \\
\text { grave. } \\
\text { Bury my name with me! } \\
\text { I wish I could become a judge so that I } \\
\text { could record all the injustices on the earth. } \\
\text { Oh, my girl, } \\
\text { the sky is dark, and the earth is dark. } \\
\text { What can be used to express my anger? } \\
\text { Only that river's tumult! } \\
\text { What can be used to comfort your } \\
\text { loneliness? } \\
\text { Only this song at midnight! }\end{array}$ & 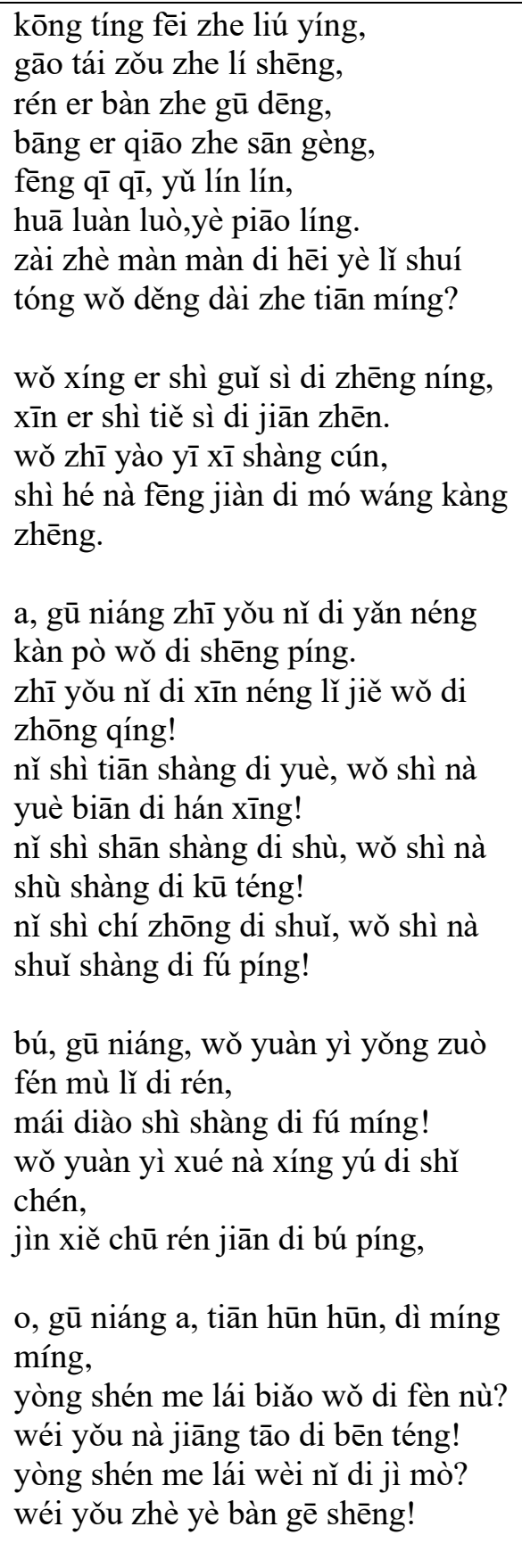 \\
\hline
\end{tabular}


Composer: Xian Xing Hai (洗星海, 1905-1945)

Piano arrangement: Li Yinghai (黎英海, 1927-2007)

Title: Huang He Song (黄河颂, 1939)

Title Translation: Ode to the Yellow River

Poet: Guang Weiran (光未然 1913-2002)

\begin{tabular}{|c|c|c|}
\hline 黄河颂 & Ode to the Yellow River & Huáng Hé Sòng \\
\hline $\begin{array}{l}\text { 我站在高山之巅, } \\
\text { 望黄河滚滚, 奔向东南。 } \\
\text { 惊涛澎湃, 掀起万丈狂澜; } \\
\text { 浊流宛转, 结成九曲连环; } \\
\text { 从昆仑山下奔向黄海之边, } \\
\text { 把中原大地䢃成南北两面。 } \\
\text { 啊! 黄河! } \\
\text { 你是中华民族的摇篮! } \\
\text { 五千年的古国文化, } \\
\text { 从你这儿发源, } \\
\text { 多少英雄的故事, } \\
\text { 在你的身边扮演。 } \\
\text { 啊! 黄河! 你伟大坚强, } \\
\text { 像一个巨人出现在亚洲平原 } \\
\text { 之上, } \\
\text { 用你那英雄的体魄, } \\
\text { 筑成我们民族的屏障。 } \\
\text { 啊! 黄河! } \\
\text { 你一泻万丈,浩浩荡荡, } \\
\text { 向南北两岸伸出千万条铁的 } \\
\text { 臂膀。 } \\
\text { 我们民族的伟大精神, } \\
\text { 将要在你的哺育下发扬滋 } \\
\text { 长! }\end{array}$ & $\begin{array}{l}\text { I stood on the top of the mountain, } \\
\text { I looked at the Yellow River. It was rolling } \\
\text { and heading southeast. } \\
\text { The storm was surging and setting off } \\
\text { mighty tides. } \\
\text { The turbid water flows and turns, forming a } \\
\text { series of nine curves. } \\
\text { The water runs from the Kunlun Mountain to } \\
\text { the edge of the Yellow Sea } \\
\text { and splits the Central Plains into two sides; } \\
\text { the north and the south. } \\
\text { Ah! Yellow River! } \\
\text { You are the cradle of the Chinese nation! } \\
\text { Five thousand years of ancient culture } \\
\text { originate from you. } \\
\text { How many hero stories } \\
\text { have played out beside you! } \\
\text { Ah! Yellow River! You are great and strong. } \\
\text { You appeared like a giant on the Asian plains } \\
\text { and used your hero's physique to build a } \\
\text { barrier for our nation. } \\
\text { Ah! Yellow River! } \\
\text { You poured down ten thousand miles } \\
\text { majestically, and extended thousands of iron } \\
\text { arms to your north and south sides. } \\
\text { The great spirit of our nation } \\
\text { will grow and develop with your nurturing! } \\
\text { Heroes and heirs of our motherland will learn } \\
\text { from you as model. } \\
\text { They will become great and strong like you! } \\
\text { Great and strong like you! }\end{array}$ & 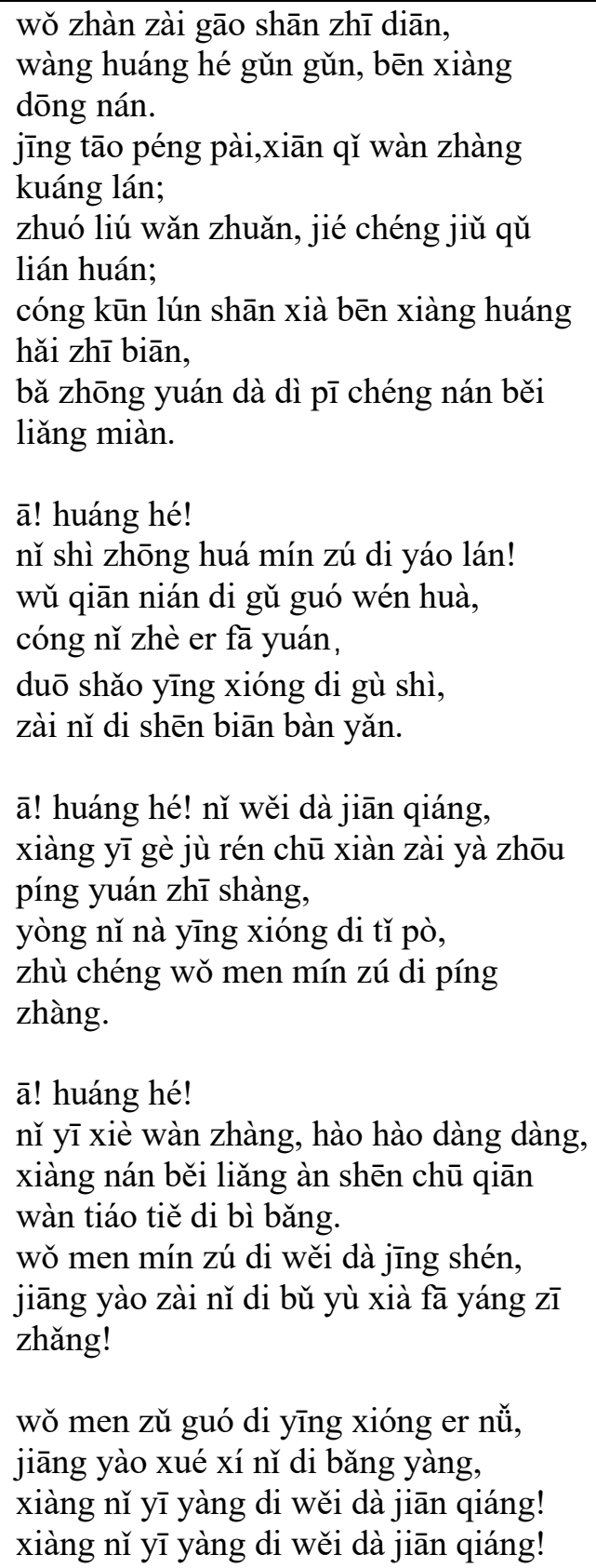 \\
\hline
\end{tabular}


Composer: Xian Xinghai (洗星海, 1905-1945)

Piano arrangement: Liu Zhang (刘庄, 1932-)

Title: Huang Shuiyao (黄水谣, 1939)

Title Translation: Yellow River Ballad

Poet: Guang Weiran (光未然 1913-2002)

\begin{tabular}{|c|c|c|}
\hline 黄水谣 & Yellow River Ballad & Huáng Shuǐ Yáo \\
\hline $\begin{array}{l}\text { 黄水奔流向东方, } \\
\text { 河流万里长. } \\
\text { 水又急, } \\
\text { 浪又高, } \\
\text { 奔腾叫啸如虎狼。 } \\
\text { 开河渠, } \\
\text { 筑堤防, } \\
\text { 河东千里成平壤。 } \\
\text { 麦苗儿肥啊, } \\
\text { 豆花儿香, } \\
\text { 男女老少喜洋洋。 } \\
\text { 自从鬼子来, } \\
\text { 百姓遭了殊! } \\
\text { 奸淫烧杀,一片凄凉, } \\
\text { 扶老携幼, 四处逃亡, } \\
\text { 丢掉了㸘娘, 回不了家乡! } \\
\text { 黄水奔流日夜忙, } \\
\text { 妻离子散, } \\
\text { 天各一方! }\end{array}$ & $\begin{array}{l}\text { The Yellow River rushes to the east. } \\
\text { The river is thousands of miles long. } \\
\text { The water rushes urgently, } \\
\text { and the waves are high. } \\
\text { It is rushing and howling like a tiger and a } \\
\text { wolf. } \\
\text { We opened the river canals, } \\
\text { and built embankments, } \\
\text { along the thousands of miles of the eastern } \\
\text { bank of the river which became farmland. } \\
\text { Wheat seedlings grew tall, } \\
\text { and soybeans smelled good. } \\
\text { All the families were full of happiness. } \\
\text { Then the invader came, } \\
\text { Since the devil came, } \\
\text { the people have suffered! } \\
\text { The invaders are sexually assaulting our } \\
\text { women, everything is burning, and it is } \\
\text { desolate. } \\
\text { Both the elderly and the young had to flee } \\
\text { everywhere. } \\
\text { I lost my father and mother and can't go } \\
\text { home! } \\
\text { Yellow water rushes day and night. } \\
\text { I lost my wife and children. } \\
\text { We are very far apart. } \\
\text { We don't know when we can meet again! }\end{array}$ & $\begin{array}{l}\text { huáng shuǐ bēn liú xiàng dōng fāng, } \\
\text { hé liú wàn lǐ zhăng. } \\
\text { shuǐ yòu jí, } \\
\text { làng yòu gāo, } \\
\text { bēn téng jiào xiào rú hǔ láng. } \\
\text { kāi hé qú, } \\
\text { zhù dī fáng, } \\
\text { hé dōng qiān lǐ chéng píng răng. } \\
\text { mài miáo er féi a, } \\
\text { dòu huā er xiāng, } \\
\text { nán nǔ lǎo shăo xǐ yáng yang. } \\
\text { zì cóng guǐ zǐ lái, } \\
\text { bǎi xìng zāo le yāng! } \\
\text { jiān yín shāo shā, yī piàn qī liáng, } \\
\text { fú lăo xié yòu, sì chù táo wáng, } \\
\text { diū diào le diē niáng, huí bú le jiā } \\
\text { xiāng! } \\
\text { huáng shuǐ bēn liú rì yè máng, } \\
\text { qī lí zǐ sàn, } \\
\text { tiān gè yī fāng! }\end{array}$ \\
\hline
\end{tabular}


Composer: Xian Xinghai (洗星海, 1905-1945)

Piano arrangement: Li Yinghai (黎英海, 1927-2007)

Title: Huang Heyuan (黄河怨, 1939)

Title Translation: Yellow River Resentment

Poet: Guang Weiran (光未然 1913-2002)

\begin{tabular}{|c|c|c|}
\hline 黄河怨 & Yellow River Resentment & Huáng Hé Yuàn \\
\hline $\begin{array}{l}\text { 风啊你不要叫喊, } \\
\text { 云啊你不要躲闪! } \\
\text { 黄河啊你不要鸣咽! } \\
\text { 今晚, } \\
\text { 我在你前面哭诉我的仇和 } \\
\text { 冤。 } \\
\text { 命啊,这样苦! } \\
\text { 生活啊,这样难! } \\
\text { 鬼子啊,你这样没心肝! } \\
\text { 宝贝啊,你死得这样惨! } \\
\text { 我和你无仇又无冤, } \\
\text { 偏让我无颜偷生在人间。 } \\
\text { 狂风啊,你不要叫喊! } \\
\text { 乌云啊,你不要躲闪, } \\
\text { 黄河的水啊, } \\
\text { 你不要鸣咽! } \\
\text { 今晚, } \\
\text { 我要投在你的怀中, } \\
\text { 洗清我的千重愁来万重冤! } \\
\text { 丈夫啊,在天边! } \\
\text { 地下啊,再团圆! } \\
\text { 你要想想妻子儿女死得这样 } \\
\text { 惨! } \\
\text { 你要替我把这笔血债清算! } \\
\text { 你要替我把这笔血债清还! }\end{array}$ & $\begin{array}{l}\text { Wind, do not shout! } \\
\text { Cloud, do not run away! } \\
\text { Yellow River, do not sob! } \\
\text { Tonight, } \\
\text { I cried in front of you about the hatred and } \\
\text { injustice that I have experienced. } \\
\text { Destiny is so bitter! } \\
\text { Life is so difficult! } \\
\text { Invader, you are so ruthless! } \\
\text { My baby, you died in a horrible way! } \\
\text { I had no unjust history with you for you to } \\
\text { avenge. } \\
\text { Nevertheless, you left me without any } \\
\text { dignity in this world. } \\
\text { Rushing wind, don't shout! } \\
\text { Dark clouds, don't run away, } \\
\text { Water of the Yellow River, } \\
\text { please don't sob! } \\
\text { Tonight, I will throw myself into your } \\
\text { arms. } \\
\text { Clear away my countless sorrows and } \\
\text { grief! } \\
\text { My husband, in the sky! } \\
\text { Let's reunite in the afterlife! } \\
\text { If you think about the death of your wife } \\
\text { and children! } \\
\text { you would have to liquidate this blood debt } \\
\text { for me! } \\
\text { You have to let the devil pay this blood } \\
\text { debt for me! }\end{array}$ & $\begin{array}{l}\text { fēng a nǐ bú yào jiào hăn, } \\
\text { yún a nǐ bú yào duǒ shăn! } \\
\text { huáng hé a nǐ bú yào wū yān! } \\
\text { jīn wăn, } \\
\text { wǒ zài nǐ qián miàn kū sù wǒ di } \\
\text { chóu hé yuān. } \\
\text { mìng a, zhè yàng kǔ! } \\
\text { shēng huó a, zhè yàng nán! } \\
\text { guǐ zǐ a, nǐ zhè yàng méi xīn gān! } \\
\text { băo bèi a, nǐ sǐ dé zhè yàng căn! } \\
\text { wǒ hé nǐ wú chóu yòu wú yuān, } \\
\text { piān ràng wǒ wú yán tōu shēng zài } \\
\text { rén jiān. } \\
\text { kuáng fēng a, nǐ bú yào jiào hăn! } \\
\text { wū yún a, nǐ bú yào duǒ shăn, } \\
\text { huáng hé di shuǐ a, } \\
\text { nǐ bú yào wū yān! } \\
\text { jīn wăn, } \\
\text { wǒ yào tóu zài nǐ di huái zhōng, } \\
\text { xǐ qīng wǒ di qiān zhòng chóu lái } \\
\text { wàn zhòng yuān! } \\
\text { zhàng fū ā, zài tiān biān! } \\
\text { dì xià ā, zài tuán yuán! } \\
\text { nǐ yào xiăng xiăng qī zǐ er nŭ sǐ di } \\
\text { zhè yàng căn! } \\
\text { nǐ yào tì wǒ bă zhè bǐ xuè zhài qīng } \\
\text { suàn! } \\
\text { nǐ yào tì wǒ bă zhè bǐ xuè zhài qīng } \\
\text { hái! }\end{array}$ \\
\hline
\end{tabular}


Composer: Ying Shangneng (应尚能, 1902-1973)

Title: Diao Wusong (吊吴淞, 1933)

Title Translation: Commemorate of the Dead Soldiers at Wu Song

Poet: Wei Hanzhang ( 韦瀚章, 1905-1993)

\begin{tabular}{|c|c|c|}
\hline 吊吴淞 & Commemorate of the Dead Soldiers at Wusong & Diào Wú Sōng \\
\hline $\begin{array}{l}\text { 春尽江南, } \\
\text { 不堪回首年前事, } \\
\text { 到如今, } \\
\text { 一寸山河一寸伤心地! }\end{array}$ & $\begin{array}{l}\text { It was the late spring in the south. } \\
\text { I can't bear to look back on the past. } \\
\text { Until now, } \\
\text { every inch of the mountains and the rivers were } \\
\text { expressing sadness! }\end{array}$ & $\begin{array}{l}\text { chūn jìn jiāng nán, } \\
\text { bú kān huí shǒu nián qián shì, } \\
\text { dào rú jīn, } \\
\text { yī cùn shān hé yī cùn shāng xīn } \\
\text { dì! }\end{array}$ \\
\hline $\begin{array}{l}\text { 极目吴淞, } \\
\text { 衰草黄沙迷废垒; } \\
\text { 愒浦暮朝生, } \\
\text { 点点都成泪, } \\
\text { 白骨青麟夜夜飞, } \\
\text { 可怜未竟千城志。 }\end{array}$ & $\begin{array}{l}\text { Gazing over the city of Wusong, I see the discarded } \\
\text { barricades remaining from the war that are covered } \\
\text { in dead grass and yellow sand. } \\
\text { When the tides rose onto the shore at dusk, } \\
\text { every bit of water became tears. } \\
\text { White bones and green scales flew here every night } \\
\text { showing the, pitiful, unfinished ambition of our } \\
\text { heroes. }\end{array}$ & $\begin{array}{l}\text { jí mù wú sōng, } \\
\text { shuāi căo huáng shā mí fèi lěi; } \\
\text { kài pǔ mù cháo shēng, } \\
\text { diăn diăn dōu chéng lèi, } \\
\text { bái gǔ qīng lín yè yè fêi, } \\
\text { kě lián wèi jìng qiān chéng zhì. }\end{array}$ \\
\hline
\end{tabular}


Composer: Zhang Hanhui (张寒晖, 1902-1946)

Piano arrangement: Zhang Dong (张栋)

Title: Songhua Jiang Shang (松花江上, 1936)

Title translation: On the Songhua River

Poet: Zhang Hanhui (张寒晖, 1902-1946)

\begin{tabular}{|c|c|c|}
\hline 松花江上 & On the Songhua River & Sōnghuā Jiāng Shàng \\
\hline $\begin{array}{l}\text { 我的家在东北松花江上, } \\
\text { 那里有森林煤矿, } \\
\text { 还有那满山遍野的大豆高 } \\
\text { 粱。 } \\
\text { 我的家在东北松花江上, } \\
\text { 那里有我的同胞, } \\
\text { 还有那衰老的爹娘。 } \\
\text { 九一八,九一八, } \\
\text { 从那个悲惨的时候! } \\
\text { 九一八,九一八! } \\
\text { 从那个悲惨的时候, } \\
\text { 脱离了我的家乡, } \\
\text { 抛弃那无尽的宝藏, } \\
\text { 流浪!流浪! } \\
\text { 整日价在关内,流浪! } \\
\text { 哪年,哪月, } \\
\text { オ能够回到我那可爱的故乡? } \\
\text { 哪年,哪月, } \\
\text { 才能够收回那无尽的宝藏? } \\
\text { 爹娘啊,爹娘啊。 } \\
\text { 什么时候, } \\
\text { オ能欢聚一堂? }\end{array}$ & $\begin{array}{l}\text { My home is on the Songhua River in } \\
\text { Northeast China. } \\
\text { There are coal mines in the forest. } \\
\text { There are soybean plants all over the } \\
\text { mountain. } \\
\text { My home is on the Songhua River in the } \\
\text { Northeast. } \\
\text { My compatriots are there. } \\
\text { So are my aging father and mother. } \\
\text { September 18th, September } 18^{\text {th }} \text {, } \\
\text { from that tragic day! } \\
\text { September } 18 \text { th, September } 18^{\text {th! }} \\
\text { from that tragic day, } \\
\text { I fled from my hometown, } \\
\text { and abandoned our endless treasures. } \\
\text { Flee! Flee! } \\
\text { We now have to flee all day to the } \\
\text { Guanzhong plain! } \\
\text { In which year, which month, } \\
\text { can I return to my lovely hometown? } \\
\text { In which year, which month, } \\
\text { will we be able to get back our endless } \\
\text { treasure? } \\
\text { Father and mother, father and mother, when, } \\
\text { will we be reunited again? }\end{array}$ & $\begin{array}{l}\text { wǒ di jiā zài dōng běi sōnghuā jiāng } \\
\text { shàng, } \\
\text { nà lǐ yǒu sēn lín méi kuàng, } \\
\text { hái yǒu nà măn shān biàn yě di dà dòu } \\
\text { gāo liáng. } \\
\text { wǒ di jiā zài dōng běi sōnghuā jiāng } \\
\text { shàng, } \\
\text { nà lǐ yǒu wǒ di tóng bāo, } \\
\text { hái yǒu nà shuāi lăo di diē niáng. } \\
\text { jiǔ yī bā, jiǔ yī bā, } \\
\text { cóng nà gè bēi căn di shí hòu! } \\
\text { jiǔ yī bā, jiǔ yì bā! } \\
\text { cóng nà gè bēi căn di shí hòu, } \\
\text { tuō lí le wǒ di jiā xiāng, } \\
\text { pāo qì nà wú jìn di băo zàng, } \\
\text { liú làng! liú làng! } \\
\text { zhěng rì jià zài guān nèi, liú làng! } \\
\text { nǎ nián, nă yuè, } \\
\text { cái néng gòu huí dào wǒ nà kě ài di } \\
\text { gù xiāng? } \\
\text { nă nián, nă yuè, } \\
\text { cái néng gòu shōu huí nà wú jìn di } \\
\text { bǎo zàng? } \\
\text { diē niáng ā, diē niáng ā. } \\
\text { shén me shí hòu, } \\
\text { cái néng huān jù yĩ táng? }\end{array}$ \\
\hline
\end{tabular}


Composer: Zhang Xiaohu (张肖虎, 1914-1997)

Title: Sheng Sheng Man: Xun Xun Mi Mi (声声慢・寻寻受受, 1933)

Title translation: Sheng Sheng Man: The Searching

Poet: Li Qingzhao (李清照, 1084-1151)

\begin{tabular}{|c|c|c|}
\hline 声声慢・寻寻受受 & Sheng Sheng Man: The Searching & $\begin{array}{l}\text { Shēng Shēng Màn • Xún Xún Mì } \\
\text { Mì }\end{array}$ \\
\hline $\begin{array}{l}\text { 寻寻受受,冷冷清清, } \\
\text { 凄凄惨惨戚戚。 } \\
\text { 乍暖还寒时候,最难将息。 } \\
\text { 三杯两盛淡酒, } \\
\text { 怎敌他、晚来风急? } \\
\text { 膺过也,正伤心, } \\
\text { 却是旧时相识。 } \\
\text { 满地黄花堆积,憔悴损, } \\
\text { 如今有谁堪摘? } \\
\text { 守着窗儿,独自怎生得黑? } \\
\text { 梧桐更兼细雨, } \\
\text { 到黄昏、点点滴滴。 } \\
\text { 这次第,怎一个愁字了得! }\end{array}$ & $\begin{array}{l}\text { It is so hard to find the things that are lost in } \\
\text { the past. } \\
\text { How could I not feel miserable? } \\
\text { In the cold season, it is very difficult to stay } \\
\text { warm and rest. Even though I have had three } \\
\text { glasses, and two more glasses of wine, } \\
\text { it is still hard for me to withstand the cold wind } \\
\text { in the evening. } \\
\text { A group of wild geese fly by, which makes me } \\
\text { feel even sadder, because they are old friends. } \\
\text { The garden is full of chrysanthemums, and } \\
\text { they are already withered. Who else would } \\
\text { want to pick them now? } \\
\text { I sit by the window quietly all day long, } \\
\text { how can I stay alone until dawn? } \\
\text { The rain is drizzling on the leaves of the Indus } \\
\text { tree. } \\
\text { It is still dripping bit by bit at dusk. } \\
\text { The word "sorrow" alone cannot begin to } \\
\text { describe this day! }\end{array}$ & 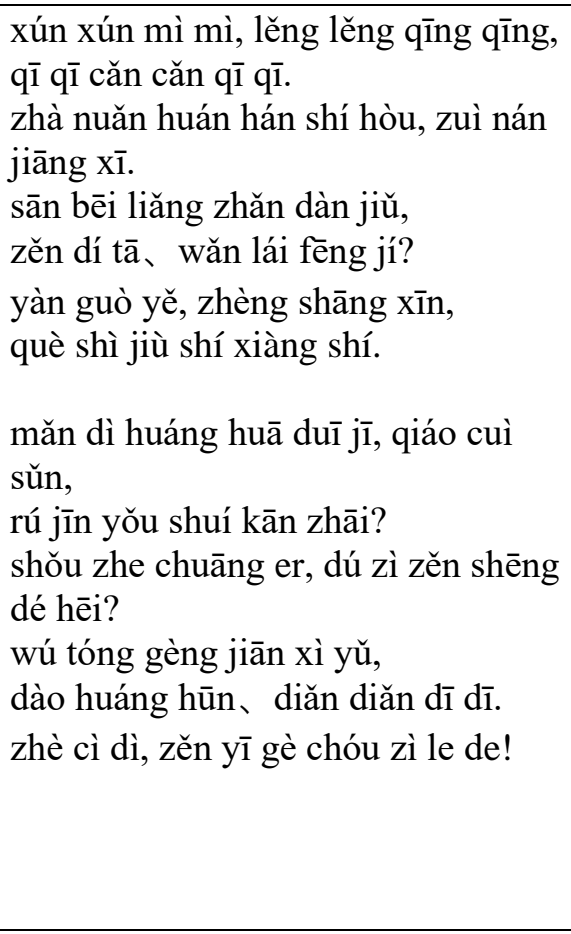 \\
\hline
\end{tabular}


Composer: Zheng Lvcheng (郑律成, 1914-1976)

Piano Arrangement: Tu Ye Jiu (屠冶九, 1927-)

Title: Yan Shui Yao (延水谣, 1938)

Title translation: The Ballade of Yan River

Poet: Xiong Fu (熊复, 1916-1995)

\begin{tabular}{|c|c|c|}
\hline 延水谣 & The Ballade of the Yan River & Yán Shuǐ Yáo \\
\hline $\begin{array}{l}\text { 延水浊,延水清, } \\
\text { 情郎哥哥去当兵, } \\
\text { 当兵啊要当抗日军, } \\
\text { 不是好铁不打钉, } \\
\text { 拿起锄头好种田,拿起枪杆上火 } \\
\text { 线,救国有名声! } \\
\text { 延水清,延水浊,小妹子来送情 } \\
\text { 郎哥, } \\
\text { 哥哥你前方去打仗,要和鬼子拼 } \\
\text { 死活, } \\
\text { 奴家织布又开荒,冬有棉衣夏有 } \\
\text { 粮,莫为奴难过。 } \\
\text { 延水浊,延水清,情郎哥哥去当 } \\
\text { 兵。 }\end{array}$ & $\begin{array}{l}\text { The Yan river is turbid, the Yan river is clear. } \\
\text { My lover is going off to the army. } \\
\text { He will be a soldier, an anti-Japanese soldier. } \\
\text { Only good iron can become a nail. } \\
\text { Pick up a hoe for good farming, } \\
\text { Pick up the firearms, and save the nation's } \\
\text { reputation! } \\
\text { The Yan river is turbid, the Yan river is clear. } \\
\text { I'm sending my lover off to the army. } \\
\text { My lover you are going to the front of the } \\
\text { war, } \\
\text { And will fight hard with the devil. } \\
\text { I will weave fabric and reclaim the unused } \\
\text { land for farming. } \\
\text { There will be warm coats in the winter and } \\
\text { enough food in the summer. Don't feel bad } \\
\text { for me. } \\
\text { The Yan river is turbid, the Yan river is clear. } \\
\text { My lover is going to the army. }\end{array}$ & 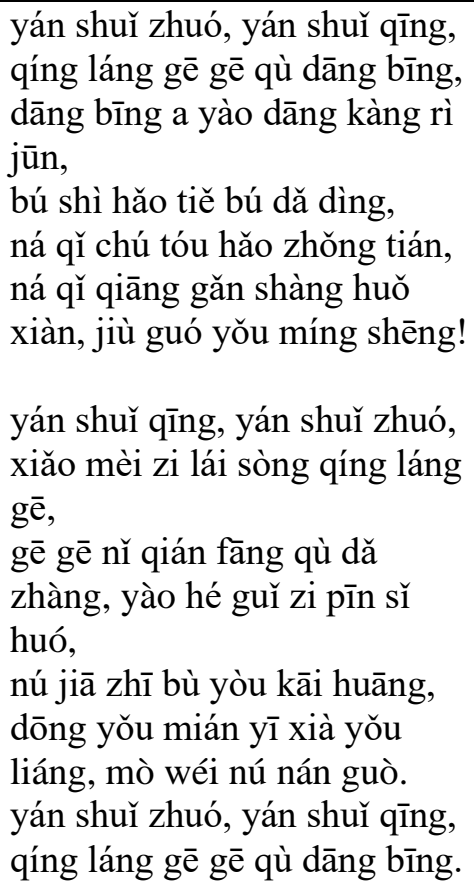 \\
\hline
\end{tabular}


Composer: Zhou Shu'an (周淑安, 1894-1974)

Title: Yu (雨, 1932)

Title Translation: Rain

Poet: Anonymous (件名)

Poem style: Modern Chinese poetry

\begin{tabular}{|c|c|c|}
\hline 雨 & Rain & Yǔ \\
\hline $\begin{array}{l}\text { 雨呀! } \\
\text { 你到底是什么东西? } \\
\text { 说你是水, } \\
\text { 你爬上天去用的什么梯? } \\
\text { 说你不是水, } \\
\text { 你落下地来怎么和水不分离? }\end{array}$ & $\begin{array}{l}\text { Rain! } \\
\text { What are you made from? } \\
\text { Say that you come from water. } \\
\text { What ladder do you use to climb up to the } \\
\text { sky? } \\
\text { Say you are not made of water, } \\
\text { Why don't you separate from the water when } \\
\text { you fall to the ground? }\end{array}$ & $\begin{array}{l}\text { yǔ ya! } \\
\text { nǐ dào dǐ shì shén me dōng xī? } \\
\text { shuō nǐ shì shuǐ, } \\
\text { nǐ pá shàng tiān qù yòng di } \\
\text { shén me tī? } \\
\text { shuō nǐ bú shì shuǐ, } \\
\text { nǐ luò xià dì lái zěn me hé shuì } \\
\text { bú fền lí? }\end{array}$ \\
\hline $\begin{array}{l}\text { 我是雨, } \\
\text { 就是水, } \\
\text { 我上天不用梯, } \\
\text { 化作云气轻轻飞。 } \\
\text { 一朝遇着冷风吹, } \\
\text { 赶快打成堆。 } \\
\text { 空中站不住, } \\
\text { 翻身直向地上回。 }\end{array}$ & $\begin{array}{l}\text { I am rain, } \\
\text { which is water. } \\
\text { I do not need a ladder to the sky, } \\
\text { I can turn in to the air of the clouds and fly } \\
\text { gently to the sky. } \\
\text { when there is a cold wind blowing, } \\
\text { the clouds pile up quickly. } \\
\text { I can't stand still in the air. } \\
\text { I turn back, straight back to the ground. }\end{array}$ & $\begin{array}{l}\text { wǒ shì yǔ, } \\
\text { jiù shì shuǐ, } \\
\text { wǒ shàng tiān bú yòng tī, } \\
\text { huà zuò yún qì qīng qīng fēi. } \\
\text { yī cháo yù zhe lěng fēng chuī, } \\
\text { găn kuài dă chéng duī. } \\
\text { kōng zhōng zhàn bú zhù, } \\
\text { fān shēn zhí xiàng dì shàng } \\
\text { huí. }\end{array}$ \\
\hline
\end{tabular}




\section{Appendix III: Lyrics and Translations for Chinese Art Songs from the 1940s}

Composer: Chen Tianhe (陈田鹤, 1911-1955)

Title: Jiang Cheng Zi (江城子, 1944)

Title translation: Jiang Cheng $\mathrm{Zi}$

Poet: Qin Guan（秦观, 1049 -1100)

\begin{tabular}{|c|c|c|}
\hline 江城子 & Jiang Cheng Zi & Jiāng Chéng Zĩ \\
\hline $\begin{array}{l}\text { 西城杨柳弄春柔, } \\
\text { 动离忧, 泪难收。 } \\
\text { 犹记多情,曾为系归 } \\
\text { 舟。 } \\
\text { 碧野朱桥当日事, } \\
\text { 人不见, 水空流。 } \\
\text { 韶华不为少年留。 } \\
\text { 恨悠悠, 几时休? } \\
\text { 飞絮落花时候一登 } \\
\text { 楼。 } \\
\text { 便做春江都是泪, } \\
\text { 流不尽, 许多愁。 }\end{array}$ & $\begin{array}{l}\text { The willows of the west City are swaying romantically in } \\
\text { the springtime. } \\
\text { They bring back my sorrow over parting with you and I } \\
\text { can't stop my tears. } \\
\text { I still remember you lovingly tying my boat upon my } \\
\text { return. } \\
\text { The green fields and the red bridge that were there that } \\
\text { year are still here. } \\
\text { Where are you now? I can't see anyone; I can only see } \\
\text { the river flowing. } \\
\text { The beautiful times of youth do not wait for the young. } \\
\text { When will my sorrow over parting with you end? } \\
\text { When the willow's catkins fly, the flowers fall, and I } \\
\text { ascend the pavilion. } \\
\text { Even if the waters of the Spring River were all tears, } \\
\text { the flow of sadness in my heart would never end. }\end{array}$ & $\begin{array}{l}\text { xī chéng yáng liǔ nòng chūn róu, } \\
\text { dòng lí yōu,lèi nán shōu. } \\
\text { yóu jì duō qíng,céng wéi xì gū̄ } \\
\text { zhōu. } \\
\text { bì yě zhū qiáo dāng rì shì, } \\
\text { rén bú jiàn, shuî kōng liú. } \\
\text { sháo huá bú wéi shăo nián liú. } \\
\text { hèn yōu yōu, jǐ shí xiū? } \\
\text { fēi xù luò huā shí hòu yī dēng lóu } \\
\text { biàn zuò chūn jiāng dōu shì lèi, } \\
\text { liú bú jìn, xǔ duō chóu. }\end{array}$ \\
\hline
\end{tabular}


Composer: Fan Jisen (范继森, 1917-1969)

Title: An Shui Ba, Yong Shi (安眠吧, 勇士, 1943)

Title translation: Rest in Pease, Warriors

Poet: Tian Han (田汉, 1898-1968)

\begin{tabular}{|c|c|c|}
\hline 安眠吧,勇士 & Rest in peace, warrior & Ān Mián Bā, Yǒng Shì \\
\hline $\begin{array}{l}\text { 安眠吧,勇士! } \\
\text { 安眠吧,勇士! } \\
\text { 用你的血写成了一首悲壮的 } \\
\text { 诗。 } \\
\text { 这是一个非常的时候, } \\
\text { 需要许多贤者的牺牲。 } \\
\text { 但是敌人哪,你别得意。 } \\
\text { 朋友啊,你也别悲伤。 } \\
\text { 这虽是黑暗的尽端, } \\
\text { 也就是光明的开始。 } \\
\text { 这虽是黑暗的尽端, } \\
\text { 也就是光明的开始。 } \\
\text { 千万人的眼泪, } \\
\text { 洗着你墓上的花枝, } \\
\text { 四万万同胞的双手, } \\
\text { 继承着你的意志。 }\end{array}$ & $\begin{array}{l}\text { Rest in peace, warrior. } \\
\text { Rest in peace, warrior. } \\
\text { An epic poem is written in your blood. } \\
\text { This is a special time. } \\
\text { Wise people will inevitably sacrifice } \\
\text { themselves. } \\
\text { The enemy is temporarily victorious, but } \\
\text { they shouldn't be proud. } \\
\text { My friends, don't be sad. } \\
\text { It's the end of the darkness, } \\
\text { and the beginning of the light. } \\
\text { It's the end of the darkness, } \\
\text { and the beginning of the light. } \\
\text { The tears of ten million people are watering } \\
\text { the flowers on your tombs. } \\
\text { Forty thousand compatriots are inheriting } \\
\text { your will. }\end{array}$ & $\begin{array}{l}\text { ān mián ba, yǒng shì ! } \\
\text { ān mián ba, yǒng shì ! } \\
\text { yòng nǐ di xuè xiě chéng le yī } \\
\text { shǒu bēi zhuàng di shī. } \\
\text { zhè shì yī gè fêi cháng di shí hòu, } \\
\text { xū yào xǔ duō xián zhě di xī } \\
\text { shēng. } \\
\text { dàn shì dí rén nă,nǐ bié dé yì. } \\
\text { péng yǒu ā, nǐ yě bié bēi shāng. } \\
\text { zhè suī shì hēi àn di jìn duān, } \\
\text { yě jiù shì guāng míng di kāi shǐ. } \\
\text { zhè suī shì hēi àn di jìn duān, } \\
\text { yě jiù shì guāng míng di kāi shǐ. } \\
\text { qiān wàn rén di yăn lèi, } \\
\text { xǐ zhe nǐ mù shàng de huā zhī, } \\
\text { sì wàn wàn tóng bāo de shuāng } \\
\text { shǒu, } \\
\text { jì chéng zhe nǐ de yì zhì. }\end{array}$ \\
\hline
\end{tabular}


Composer: Huang Yongxi (黄永熙, 1917-2003)

Title: Huai Nian Qu (怀念曲, 1940s)

Title translation: The Yearning Song

Poet: Mao Yu (毛羽,)

\begin{tabular}{|l|l|l|}
\hline 怀念曲 & The Yearning Song & Huái Niàn Qū \\
\hline $\begin{array}{l}\text { 把印着泪痕的笺, } \\
\text { 交给那旅行的水, } \\
\text { 何时流到你屋边, } \\
\text { 让它弹动你心弦。 }\end{array}$ & $\begin{array}{l}\text { The letter is stained by my tears, } \\
\text { and I let it float to you on the running water. } \\
\text { When will it get to your house and into your heart? } \\
\text { Let it play music on the strings of your heart? }\end{array}$ & $\begin{array}{l}\text { bă yìn zhe lèi hén de jiān, } \\
\text { jiāo gěi nà lü háng de shǔ́, } \\
\text { hé shí liú dào nǐ wū biān, } \\
\text { ràng tā dàn dòng nǐ xīn xián. }\end{array}$ \\
$\begin{array}{l}\text { 我曾问南归的燕, } \\
\text { 可带来你的消息? } \\
\begin{array}{l}\text { 它为我命运鸣咽, } \\
\text { 希望似梦,心无依。 }\end{array}\end{array}$ & $\begin{array}{l}\text { They hed swallows from the south } \\
\text { My hope is just a dream and my hearn de yàn, }\end{array}$ \\
\hline
\end{tabular}


Composer: Huang Youdi (黄友棣, 1911-2010)

Title: Du Juan Hua (杜鹃花, 1941)

Title translation: The Rhododendron

Poet: Wu Jun (芜军, 1898-1968)

\begin{tabular}{|c|c|c|}
\hline 杜鹃花 & The Rhododendron & Dù Juān Huā \\
\hline $\begin{array}{l}\text { 淡淡的三月天, } \\
\text { 杜鹃花开在山坡上, } \\
\text { 杜鹃花开在小溪畔, } \\
\text { 多美丽啊! } \\
\text { 像村家的小姑娘, } \\
\text { 像村家的小姑娘。 } \\
\text { 去年,村家小姑娘, } \\
\text { 走到山坡上, } \\
\text { 和情郎唱支山歌, } \\
\text { 摘枝杜鹃花插在头发上, } \\
\text { 今年,村家小姑娘, } \\
\text { 走向小溪畔, } \\
\text { 杜鹃花谢了又开呀! } \\
\text { 记起了战场上的情郎。 } \\
\text { 摘下一支鲜红的杜鹃, } \\
\text { 遥望着烽火的天边, } \\
\text { 哥哥! 你打胜仗回来, } \\
\text { 我把杜鹃花,插在你的胸前, } \\
\text { 不再插在自己的头发上。 }\end{array}$ & $\begin{array}{l}\text { In March, } \\
\text { the rhododendron bloom on the hillside. } \\
\text { The rhododendron is blooming by the creek. } \\
\text { How beautiful. } \\
\text { Like the young girl from the village, } \\
\text { like the young girl from the village. } \\
\text { Last year, } \\
\text { the young girl walked up the hillside } \\
\text { singing a mountain song with her lover } \\
\text { and picking rhododendron to decorate her hair. } \\
\text { This year, } \\
\text { the young girl walks towards the creek. } \\
\text { The rhododendron withers and blooms, } \\
\text { remembering her lover on the war field. } \\
\text { She picks a bright red rhododendron flower } \\
\text { and stares at the distant sky. } \\
\text { "My lover, when will you come back home so I } \\
\text { can put rhododendron on your chest } \\
\text { instead of in my hair?" }\end{array}$ & $\begin{array}{l}\text { dàn dàn di sān yuè tiān, } \\
\text { dù juān huā kāi zài shān pō shàng, } \\
\text { dù juān huā kāi zài xiăo xī pàn, } \\
\text { duō měi lì ā! } \\
\text { xiàng cūn jiā di xiăo gū niáng, } \\
\text { xiàng cūn jiā di xiăo gū niáng. } \\
\text { qù nián,cūn jiā xiăo gū niáng, } \\
\text { zóu dào shān pō shàng, } \\
\text { hé qíng láng chàng zhī shān gē, } \\
\text { zhāi zhī dù juān huā chā zài tóu fā } \\
\text { shàng, } \\
\text { jīn nián, cūn jiā xiăo gū niáng, } \\
\text { zǒu xiàng xiăo xī pàn, } \\
\text { dù juān huā xiè le yòu kāi ya! } \\
\text { jì qǐ le zhàn chăng shàng di qíng } \\
\text { láng. } \\
\text { zhāi xià yī zhī xiān hóng di dù } \\
\text { juān, } \\
\text { yáo wàng zhe fēng huǒ di tiān } \\
\text { biān, } \\
\text { gē gē! nǐ dă shèng zhàng huí lái, } \\
\text { wǒ bă dù juān huā,chā zài nǐ di } \\
\text { xiōng qián, } \\
\text { bú zài chā zài zì jǐ di tóu fā shàng. }\end{array}$ \\
\hline
\end{tabular}


Composer: Jin Sha (金眇, 1922-1996)

Piano arrangement: Li Xi'an (李西安, 1937-)

Title: Mu Yang Gu Niang (牧羊姑娘, 1941)

Title translation: The Shepherd Girl

Poet: Di Fan (荻帆, 1917-1995)

\begin{tabular}{|c|c|c|}
\hline 牧羊姑娘 & The Shepherd Girl & Mù Yáng Gū Niáng \\
\hline $\begin{array}{l}\text { 对面山上的姑娘, } \\
\text { 你为谁放着群羊? } \\
\text { 泪水湿透了你的衣裳, } \\
\text { 你为什么这样悲伤? } \\
\text { 山上这样的荒凉, } \\
\text { 草儿是这样枯黄, } \\
\text { 羊儿再没有食粮, } \\
\text { 主人的鞭儿举起了抽在我身 } \\
\text { 上。 }\end{array}$ & $\begin{array}{l}\text { (I say) } \\
\text { The girl on the opposite hill, } \\
\text { who do you keep tending the sheep for? } \\
\text { Tears have drenched your clothes. } \\
\text { Why are you so sad? } \\
\text { (The girl says) } \\
\text { Look at the desolate mountains. } \\
\text { The grass is so withered and yellow. } \\
\text { The sheep don't have food anymore. } \\
\text { My master uses the whip to beat me. } \\
\text { (I say) } \\
\text { The girl on the opposite hill, } \\
\text { the wind is so bleak at dusk, } \\
\text { and you are wearing thin clothes. } \\
\text { Why don't you go back to your village? } \\
\text { (The girl said) } \\
\text { The cold north wind chills me. } \\
\text { I don't want to go back to the village anymore, } \\
\text { I'd rather lean against the sheep. } \\
\text { My master's butcher is ready to kill my sheep. }\end{array}$ & $\begin{array}{l}\text { duì miàn shān shàng di gū niáng, } \\
\text { nǐ wéi shuí fàng zhe qún yáng? } \\
\text { lèi shuǐ shì tòu le nǐ di yī shang, } \\
\text { nǐ wéi shí me zhè yàng bēi shāng? } \\
\text { shān shàng zhè yàng di huāng } \\
\text { liáng, } \\
\text { cǎo ér shì zhè yàng kū huáng, } \\
\text { yáng ér zài méi yǒu shí liáng, } \\
\text { zhǔ rén di biān ér jǔ qǐ le chōu zài } \\
\text { wǒ shēn shàng. } \\
\text { duì miàn shān shàng di gū niáng, } \\
\text { nà huáng hūn fēng chuī di hăo qī } \\
\text { liáng! } \\
\text { chuān di shì báo báo di yī shang, } \\
\text { nî wéi shí me hái bú huí cūn } \\
\text { zhuāng? } \\
\text { běi fēng chuī dé wǒ bīng liáng, } \\
\text { wǒ yuàn kào zài yáng ér shēn } \\
\text { páng, } \\
\text { zài yě bú yuàn huí cūn zhuāng, } \\
\text { zhǔ rén di tú dāo shăn liàng liàng } \\
\text { yào zăi wǒ di yáng. }\end{array}$ \\
\hline
\end{tabular}


Piano arrangement: Jiang Dingxian (江定仙, 1922-1996)

Title: Kangding Qing Ge (康定情歌, 1940s)

Title translation: Kongding Love Song

Poet: Sichuan Folk Song

\begin{tabular}{|c|c|c|}
\hline 康定情歌 & Kangding Love Song & Kāng Dìng Qíng Gē \\
\hline $\begin{array}{l}\text { 跑马(溜溜的)山上一朵(溜溜的) } \\
\text { 云哟, } \\
\text { 端端(溜溜的)照在康定(溜溜的) } \\
\text { 城哟, } \\
\text { 月亮弯弯, } \\
\text { 康定(溜溜的)城哟。 } \\
\text { 李家(溜溜的)大姐人才(溜溜的) } \\
\text { 好哟, } \\
\text { 张家(溜溜的)大哥看上(溜溜的) } \\
\text { 她哟, } \\
\text { 月亮弯弯, 看上(溜溜的)她哟。 }\end{array}$ & $\begin{array}{l}\text { A cloud floats above the Running Horse } \\
\text { Hill, } \\
\text { and shines brightly over the city of } \\
\text { Kangding. } \\
\text { The moon is beautiful, } \\
\text { so is Kangding City. } \\
\text { The maid from the Li family is talented. } \\
\text { A man from the Zhang family falls in } \\
\text { love with her. } \\
\text { The moon is beautiful, } \\
\text { and the man falls in love with the maid. } \\
\text { The man falls in love with her } \\
\text { because she is talented, } \\
\text { because she is good at housework, and } \\
\text { because the moon is beautiful. } \\
\text { The man in the Zhang Family said, "all } \\
\text { the women in the world are so beautiful } \\
\text { that I could fall in love with any of } \\
\text { them. } \\
\text { The men in the world are going to } \\
\text { pursue love. } \\
\text { The moon is beautiful, and } \\
\text { the men will pursue love." }\end{array}$ & $\begin{array}{l}\text { păo mă (liū liū di) shān shàng yī duǒ } \\
\text { (liū liū di) yún yō, } \\
\text { duān duān (liū liū di) zhào zài kāng dìng } \\
\text { (liū liū di) chéng yō, } \\
\text { yuè liàng wān wān, } \\
\text { kāng dìng (liū liū di) chéng yō. } \\
\text { lî jiā (liū liū di) dà jiě rén cái (liū liū di) } \\
\text { hăo yō, } \\
\text { zhāng jiā (liū liū di) dà gē kàn shàng } \\
\text { (liū liū di) tā yō, } \\
\text { yuè liàng wān wān,kàn shàng (liū liū } \\
\text { di )tā yō. } \\
\text { yī lái (liū liū di) kàn shàng rén cái (liū } \\
\text { liū di) hăo yō, } \\
\text { èr lái (liū liū di) kàn shàng huì dāng (liū } \\
\text { liū di) jiā yō, } \\
\text { yuè liàng wān wān,huì dāng (liū liū di ) } \\
\text { jiā yō! } \\
\text { shì jiān (liū liū di) nŭ zǐ rèn wǒ (liū liū } \\
\text { di) ài yō, } \\
\text { shì jiān (liū liū di) nán zǐ rèn nǐ (liū liū } \\
\text { di) qiú yō, } \\
\text { yuè liàng wān wān,rèn nǐ (liū liū di ) qiú } \\
\text { yō. }\end{array}$ \\
\hline
\end{tabular}


Composer: Lin Shengxi (林声翕, 1914-1991)

Title: Shui Diao Ge Tou: Ming Yue Ji Shi You (水调歌头・明月几时有, 1942)

Title translation: The Prelude of the Water Tune: How Long Until the Full Moon Appears?

Poet: Su Shi (苏轼, 1037-1101)

\begin{tabular}{|c|c|c|}
\hline 水调歌头・明月几时有 & $\begin{array}{l}\text { The Prelude of the Water Tune: How Long } \\
\text { Until the Full Moon Appears? }\end{array}$ & $\begin{array}{l}\text { Shuǐ Diào Gē Tóu・Míng Yuè Jĩ } \\
\text { Shí Yǒu }\end{array}$ \\
\hline $\begin{array}{l}\text { 明月几时有? 把酒问青天。 } \\
\text { 不知天上宫阙, 今夕是何年? } \\
\text { 我欲乘风归去, } \\
\text { 又恐琼楼玉宇, 高处不胜寒。 } \\
\text { 起舞弄清影, } \\
\text { 何似在人间。 } \\
\text { 转朱阁, 低绮户,照无眠。 } \\
\text { 不应有恨, 何事长向别时圆? } \\
\text { 人有悲欢离合, 月有阴晴圆缺, } \\
\text { 此事古难全。 } \\
\text { 但愿人长久, } \\
\text { 千里共婵娟。 }\end{array}$ & $\begin{array}{l}\text { "How long until the full moon appears?" I } \\
\text { would ask the sky with a cup of wine in my } \\
\text { hand. } \\
\text { I don't know which year it is now in the palace } \\
\text { of heaven. } \\
\text { I want to ride the wind and go to heaven, } \\
\text { but I'm afraid the palace is too high and too } \\
\text { cold. } \\
\text { I rise and dance with my shadow, } \\
\text { and it doesn't seem like the human world } \\
\text { anymore. } \\
\text { The moonlight turns around the red house, and } \\
\text { through the lower window, it shines on me, } \\
\text { sleepless. } \\
\text { "Moon, do you have any regret? Why do you } \\
\text { choose to be full when people are parting with } \\
\text { each other?" } \\
\text { Life has joys and sorrows. People part ways and } \\
\text { unite. } \\
\text { The moon changes its phase from part to full. } \\
\text { Since ancient times, things have never remained } \\
\text { the same. } \\
\text { I just hope that all the loved ones in this world } \\
\text { can be safe and healthy. } \\
\text { Even if they are thousands of miles apart, they } \\
\text { can share this beautiful moonlight. }\end{array}$ & $\begin{array}{l}\text { míng yuè jǐ shí yǒu? bǎ jiǔ wèn } \\
\text { qīng tiān. } \\
\text { bú zhī tiān shàng gōng què, jīn xī } \\
\text { shì hé nián? } \\
\text { wǒ yù chéng fēng guī qù, } \\
\text { yòu kǒng qióng lóu yù yǔ, gāo chù } \\
\text { bú shèng hán. } \\
\text { qî wǔ nòng qīng yinng, } \\
\text { hé sì zài rén jiān . } \\
\text { zhuăn zhū gé, } \\
\text { dī qǐ hù,zhào wú mián. } \\
\text { bú yīng yǒu hèn, } \\
\text { hé shì zhăng xiàng bié shí yuán? } \\
\text { rén yǒu bēi huān lí hé, } \\
\text { yuè yǒu yīn qíng yuán quē, } \\
\text { cǐ shì gǔ nán quán. } \\
\text { dàn yuàn rén zhăng jiǔ, } \\
\text { qiān lǐ gòng chán juān. }\end{array}$ \\
\hline
\end{tabular}


Composer: Liu Xue'an (刘雪庵, 1905-1985)

Piano arrangement: Sang Tong (桑桐, 1923-2011)

Title: Hong Dou Ci (红豆词, 1943)

Title translation: The Poem of the Red Beans

Poet: Cao Xueqin (曹雪芹, 1715-1763)

\begin{tabular}{|c|c|c|}
\hline 红豆词 & The Poem of the Red Beans & Hóng Dòu Cí \\
\hline $\begin{array}{l}\text { 滴不尽相思血泪抛红豆, } \\
\text { 开不完春柳春花满画楼, } \\
\text { 睡不稳纱窗风雨黄昏后, } \\
\text { 忘不了新愁与旧愁。 } \\
\text { 咽不下王粒金莼噎满喉, } \\
\text { 照不见菱花镜里形容瘦, } \\
\text { 展不开眉头,捱不明更漏, } \\
\text { 啊! } \\
\text { 恰似遮不住的青山隐隐, } \\
\text { 流不断的绿水悠悠. }\end{array}$ & $\begin{array}{l}\text { With endless blood and tears for my longing, I } \\
\text { throw the red beans. }{ }^{87} \\
\text { The art building is full of endless Spring } \\
\text { willows and flowers. } \\
\text { I can't forget my new sorrow or my old } \\
\text { sorrows. } \\
\text { I can't swallow the jade-like grains and the } \\
\text { gold-like liquid. } \\
\text { I can't see the thin maid in the Linghua Mirror. } \\
\text { The sadness appears on my eyebrow. } \\
\text { I can't wait by the unclear water clock anymore. } \\
\text { Ah! } \\
\text { It is just like the partially hidden mountain in } \\
\text { the distance and the endlessly flowing green } \\
\text { water. }\end{array}$ & $\begin{array}{l}\text { dī bú jìn xiàng sī xuè lèi pāo hóng } \\
\text { dòu, } \\
\text { kāi bú wán chūn liǔ chūn huā } \\
\text { măn huà lóu, } \\
\text { shuì bú wěn shā chuāng fēng yǔ } \\
\text { huáng hūn hòu, } \\
\text { wàng bú le xīn chóu yǔ jiù chóu. } \\
\text { yān bú xià yù lì jīn chún yē măn } \\
\text { hóu, } \\
\text { zhào bú jiàn líng huā jìng lǐ xíng } \\
\text { róng shòu, } \\
\text { zhăn bú kāi méi tóu,ái bú míng } \\
\text { gèng lòu, } \\
\text { ā! } \\
\text { qià sì zhē bú zhù di qīng shān yǐn } \\
\text { y̌nn, } \\
\text { liú bú duàn di lù̀ shuǐ yōu yōu. }\end{array}$ \\
\hline
\end{tabular}

\footnotetext{
${ }^{87}$ In this poem, red beans symbolize lovesickness which pulls on typical symbolism prominent in much of Chinese literature.
} 
Composer: Ma Ke (马克, 1918-1976)

Title: Nan Ni Wan (南泥湾, 1943)

Title translation: The Nanni Bay

Poet: He Jingzhi (贺敬之, 1924-)

\begin{tabular}{|c|c|c|}
\hline 南泥湾 & The Nanni Bay & Nán Ní Wān \\
\hline $\begin{array}{l}\text { 花篮的花儿香, } \\
\text { 听我来唱一唱唱一(呀)唱, } \\
\text { 来到了南泥湾, } \\
\text { 南泥湾好地方好地(呀)方, } \\
\text { 好地方(来)好风光, } \\
\text { 好地方(来)好风光, } \\
\text { 到处是庄稼, } \\
\text { 遍地是牛羊。 } \\
\text { 往年的南泥湾, } \\
\text { 处处是荒山没(呀)人烟, } \\
\text { 如今的南泥湾, } \\
\text { 与往年不一般不一(呀)般, } \\
\text { 如(呀)今的南泥湾, } \\
\text { 与(呀)往年不一般, } \\
\text { 再不是旧模样, } \\
\text { 是陕北的好江南。 } \\
\text { 陕北的好江南, } \\
\text { 鲜花开满山开(呀)满山, } \\
\text { 学习那南泥湾, } \\
\text { 处处是江南是江(呀)南, } \\
\text { 又学习来又生产, } \\
\text { 三五九旅是模范, } \\
\text { 咱们走向前, } \\
\text { 鲜花送模范。 }\end{array}$ & $\begin{array}{l}\text { The flowers in the basket are fragrant. } \\
\text { Listen to me sing a little song, } \\
\text { sing a little song. } \\
\text { Come to Nanni Bay, } \\
\text { Nanni Bay is a nice place. } \\
\text { It is a nice place with beautiful scenery. } \\
\text { It is a nice place with beautiful scenery. } \\
\text { Crops are everywhere, } \\
\text { Cattle and sheep are all around. } \\
\text { In the past, Nanni Bay was a barren } \\
\text { mountain with no people around. } \\
\text { Today, Nanni Bay is different from the past. } \\
\text { Today, Nanni Bay is different from the past. } \\
\text { It is not like it was in the past anymore. } \\
\text { It is like the Jiangnan region of Northern } \\
\text { Shanxi province.88 } \\
\text { The mountains are full of flowers. } \\
\text { Let's learn from the experiences of Nanni } \\
\text { Bay. } \\
\text { Then everywhere will be like the Jiangnan } \\
\text { region. } \\
\text { Let's learn how to cultivate and farm. } \\
\text { The } 359 \text { th Brigade are our models. } \\
\text { Let's go forward. } \\
\text { Let's give flower bouquets to our models. }\end{array}$ & $\begin{array}{l}\text { huā lán di huā ér xiāng, } \\
\text { tīng wǒ lái chàng yī chàng } \\
\text { chàng yī (ya )chàng, } \\
\text { lái dào le nán ní wān, } \\
\text { nán ní wān hăo dì fāng hăo dì } \\
\text { (ya )fāng, } \\
\text { hăo dì fāng (lái )hăo fēng } \\
\text { guāng, } \\
\text { hăo dì fāng (lái )hăo fēng } \\
\text { guāng, } \\
\text { dào chù shì zhuāng jià, } \\
\text { biàn dì shì niú yáng. } \\
\text { wăng nián de nán ní wān, } \\
\text { chù chù shì huāng shān méi } \\
\text { (ya )rén yān, } \\
\text { rú jīn di nán ní wān, } \\
\text { yǔ wăng nián bú yī bān bú yī } \\
\text { (ya )bān, } \\
\text { rú (ya )jīn di nán ní wān, } \\
\text { yǔ (ya )wăng nián bú yī bān, } \\
\text { zài bú shì jiù mó yàng, } \\
\text { shì shăn běi di hăo jiāng nán. } \\
\text { shăn běi di hăo jiāng nán, } \\
\text { xiān huā kāi măn shān kāi } \\
\text { (ya )măn shān, } \\
\text { xué xí nà nán ní wān, } \\
\text { chù chù shì jiāng nán shì jiāng } \\
\text { (ya )nán, } \\
\text { yòu xué xí lái yòu shēng chăn, } \\
\text { sān wǔ jiǔ lü shì mó fàn, } \\
\text { zán men zǒu xiàng qián, } \\
\text { xiān huā sòng mó fàn. }\end{array}$ \\
\hline
\end{tabular}

\footnotetext{
${ }^{88}$ During this period, the Jiangnan region was a model city renowned for its wealth and prosperity. It is used here as a form of comparison to indicate Nanni Bay's prosperity.
} 
Composer: Ma Sicong (马思聪, 1912-1987)

Title: Hai Shang (海上, 1943)

Title translation: On the Sea

Poet: Guo Moruo (郭沫若, 1892-1978)

\begin{tabular}{|c|c|c|}
\hline 海上 & On the Sea & Hăi Shàng \\
\hline $\begin{array}{l}\text { 夕阳, } \\
\text { 瞬息万变的霞光, } \\
\text { 西方的那朵木星呦! } \\
\text { 又巨,又郎。 } \\
\text { 那儿的下面, } \\
\text { 便是昨儿别了的故乡, } \\
\text { 风吹雨打的故乡。 } \\
\text { 你虽是雨打风吹, } \\
\text { 我总觉心儿惆怅。 } \\
\text { 欲圆未圆的月亮, } \\
\text { 已高高挂在天上, } \\
\text { 旷渺无迹的光泼。 } \\
\text { 大海平铺, } \\
\text { 大船直往。 } \\
\text { 愿我有无限的生涯, } \\
\text { 永在这无际之中彷徨, } \\
\text { 彷得,彷徨。 }\end{array}$ & $\begin{array}{l}\text { The sunset has an ever-changing glow. } \\
\text { Jupiter in the West } \\
\text { is huge and bright. } \\
\text { Down there is the hometown I left yesterday. } \\
\text { My hometown was hit by wind and rain. } \\
\text { Knowing that, } \\
\text { I always feel intimidated. } \\
\text { For there is an unrounded moon that hangs high } \\
\text { up in the sky. } \\
\text { There were the light waves that left without a } \\
\text { trace. } \\
\text { The sea is tiled. } \\
\text { The ship went straight. } \\
\text { May I have an unlimited lifetime. } \\
\text { I will stay in this boundless world wondering } \\
\text { forever. } \\
\text { Wondering, wondering, and wondering. }\end{array}$ & 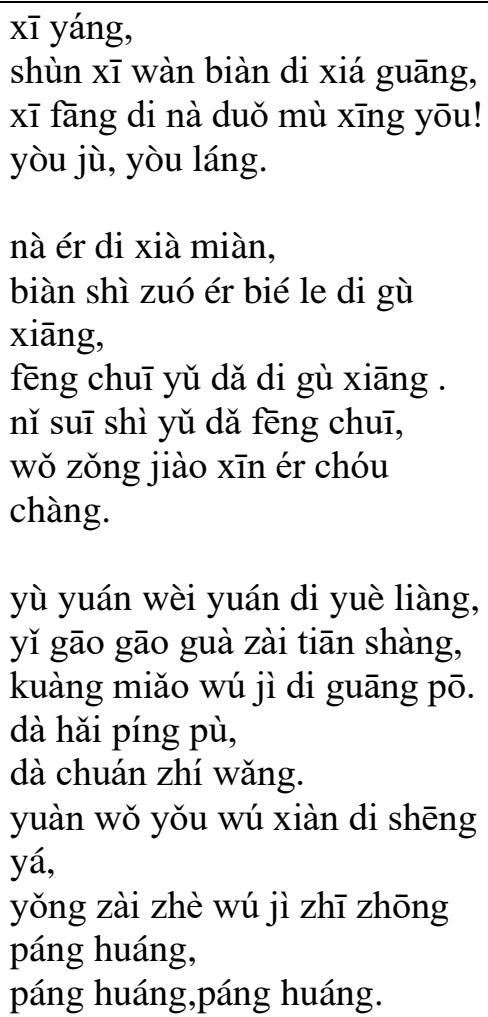 \\
\hline
\end{tabular}


Composer: Tan Xiaolin (谭小麟, 1912-1948)

Title: Bie Li (别离, 1946)

Title translation: Saying Goodbye

Poet: Guo Moruo (郭沫若, 1892-1978)

\begin{tabular}{|c|c|c|}
\hline 别离 & Saying Goodbye & Bié Lí \\
\hline $\begin{array}{l}\text { 惨月黄金梳, } \\
\text { 我欲捜之赠彼姝。 } \\
\text { 彼姝不可见, } \\
\text { 桥下流泉声如泫。 } \\
\text { 晓日月桂冠, } \\
\text { 掇之欲上青天难. } \\
\text { 青天犹可上, } \\
\text { 生离令我情惆怅。 }\end{array}$ & $\begin{array}{l}\text { The waning moon is shaped like a gold comb. } \\
\text { I want to take it out of the sky and give it to her. } \\
\text { But she's not here. } \\
\text { The sound of the spring dripping under the bridge is still } \\
\text { there. } \\
\text { The morning sun looks like a crown. } \\
\text { It's too difficult for me to go up to the heavens and take the } \\
\text { crown down. } \\
\text { Even if I climbed up to the heavens, } \\
\text { she would still leave me. } \\
\text { (What's the use?) } \\
\text { My love is full of sadness. }\end{array}$ & $\begin{array}{l}\text { căn yuè huáng jīn shū, } \\
\text { wǒ yù duō zhī zèng bǐ } \\
\text { shū. } \\
\text { bǐ shū bú kě jiàn, } \\
\text { qiáo xià liú quán shēng } \\
\text { rú xuàn. } \\
\text { xiăo rì yuè guì guàn, } \\
\text { duō zhī yù shàng qīng } \\
\text { tiān nán. } \\
\text { qīng tiān yóu kě shàng, } \\
\text { shēng lí lìng wǒ qíng } \\
\text { chóu chàng. }\end{array}$ \\
\hline
\end{tabular}


Composer: Tan Xiaolin (谭小麟, 1912-1948)

Title: Zheng Qi Ge (正气歌, 1947)

Title translation: The Song of Righteousness

Poet: Wen Tianxiang (文天祥, 1236-1283)

\begin{tabular}{|c|c|c|}
\hline 正气歌 & The Song of Righteousness & Zhèng Qì Gē \\
\hline $\begin{array}{l}\text { 天地有正气, 杂然赋流 } \\
\text { 形。 } \\
\text { 下则为河岳, 上则为日 } \\
\text { 星。 } \\
\text { 於人曰浩然, 沛乎塞苍 } \\
\text { 冥。 } \\
\text { 皇路当清夷, 含和吐明 } \\
\text { 庭。 } \\
\text { 时穷节乃见, 一一垂丹 } \\
\text { 青。 } \\
\text { 是气所磅礴, 凛烈万古 } \\
\text { 存。 } \\
\text { 当其贯日月, 生死安足 } \\
\text { 论。 }\end{array}$ & $\begin{array}{l}\text { There is a sense of righteousness between the sky and the } \\
\text { earth, } \\
\text { which empowers all things and changes them into various } \\
\text { shapes. } \\
\text { This righteousness appears as mountains and rivers on the } \\
\text { earth and as the sun, moon, and stars in the sky. } \\
\text { It is known in the world as Hao Ran Qi. } \\
\text { It is full of sky, earth, and the universe. } \\
\text { When our country is peaceful and prosperous, it will have } \\
\text { a calm atmosphere and a progressive government. } \\
\text { When our country is in difficult times, the righteous will } \\
\text { appear. Their heroic stories will be written in history one } \\
\text { by one. } \\
\text { This righteousness (means Haoran Qi) filled the universe. } \\
\text { Justice is inviolable and enduring. } \\
\text { When this righteousness runs from the earth to the sky and } \\
\text { hits the sun and moon there will be no need to talk about } \\
\text { being alive or dead! }\end{array}$ & $\begin{array}{l}\text { tiān dì yǒu zhèng qì, zá rán } \\
\text { fù liú xíng . } \\
\text { xià zé wéi hé yuè, shàng zé } \\
\text { wéi rì xīng. } \\
\text { yú rén yuē hào rán, pèi hū } \\
\text { sāi cāng míng. } \\
\text { huáng lù dāng qīng yí, hán } \\
\text { hé tǔ míng tíng. } \\
\text { shí qióng jiē năi jiàn, yī yī } \\
\text { chuí dān qīng. } \\
\text { shì qì suó páng bó, lǐn liè } \\
\text { wàn gŭ cún. } \\
\text { dāng qí guàn rì yuè, shēng sǐ } \\
\text { àn zú lùn. }\end{array}$ \\
\hline
\end{tabular}


Composer: Tan Xiaolin (谭小麟, 1912-1948)

Title: Zi Jun Zhi Chu Yi (自君之出矣, 1945)

Title translation: Since the Day of Your Departure

Poet: Zhang Jiuling (张九龄, 678-740)

\begin{tabular}{|c|c|c|}
\hline 自君之出矣 & Since the Day of Your Departure & Zì Jūn Zhī Chū Yr̃ \\
\hline $\begin{array}{l}\text { 自君之出矣, 不复理残 } \\
\text { 机。 } \\
\text { 思君如满月, 夜夜减清 } \\
\text { 辉。 }\end{array}$ & $\begin{array}{l}\text { I have not touched the old weaving machine since you } \\
\text { started traveling and left our home. } \\
\text { Missing you is like observing the full moon in the sky. } \\
\text { Night after night, the moonlight fades. }\end{array}$ & $\begin{array}{l}\text { zì jun1 zhī chū yǐ,bú fù lǐ } \\
\text { cán jī. } \\
\text { sī jun1 rú măn yuè,yè yè } \\
\text { jiăn qīng huî. }\end{array}$ \\
\hline
\end{tabular}


Composer: Tan Xiaolin (谭小麟, 1912-1948)

Title: Peng Lang Ji (彭浪矶, 1944)

Title translation: The Penglang Rock

Poet: Zhu Dunru (朱敦儒, 1081－1159)

\begin{tabular}{|c|c|c|}
\hline 彭浪矶 & The Penglang Rock & Péng Làng $\mathrm{J}_{1}$ \\
\hline $\begin{array}{l}\text { 扁舟去作江南客, } \\
\text { 旅雁孤云。 } \\
\text { 万里烟尘, } \\
\text { 回首中原泪满巾! } \\
\text { 碧山对晚汀洲冷, } \\
\text { 枫叶芦根。 } \\
\text { 日落波平, } \\
\text { 愁损辞乡去国人。 }\end{array}$ & $\begin{array}{l}\text { I'm heading to the South region by boat for refuge. } \\
\text { I feel like a wild goose missing from the group, and a } \\
\text { lonely cloud. } \\
\text { I'm traveling in a smoky fog that never ends. } \\
\text { I look back to the Central region of China. } \\
\text { Now I am full of tears. } \\
\text { I feel a breeze of coolness as I look at the green mountain } \\
\text { that faces the flat ground by the river water. } \\
\text { The maple leaves and reed roots. } \\
\text { The sun goes down, and the waves calm down. } \\
\text { I took all my resentment with me when I left hometown. }\end{array}$ & $\begin{array}{l}\text { biăn zhōu qù zuò jiāng nán kè, } \\
\text { lǜ yàn gū yún. } \\
\text { wàn lǐ yān chén, } \\
\text { huí shǒu zhōng yuán lèi măn } \\
\text { jīn! } \\
\text { bì shān duì wăn tīng zhōu lěng, } \\
\text { fēng yè lú gēn. } \\
\text { rì luò bō píng. } \\
\text { chóu sǔn cí xiāng qù guó rén. }\end{array}$ \\
\hline
\end{tabular}


Composer: Xian Xinghai (洗星海, 1905-1945)

Title: Yi Qin'e: Xiao Shengyan (忆秦娥・箫声咽, 1940)

Title translation: Memories of Qin'e: Weeping Flute

Poet: Li Bai (李白, 701－762)

\begin{tabular}{|c|c|c|}
\hline 忆秦娥・箫声咽 & Memories of Qin'e: Weeping Flute & $\begin{array}{l}\text { Yì Qín É • Xiāo } \\
\text { Shēng Yān }\end{array}$ \\
\hline $\begin{array}{l}\text { 箫声咽, } \\
\text { 秦娥梦断秦楼月。 } \\
\text { 秦楼月, } \\
\text { 年年柳色, } \\
\text { 灞陵伤别。 } \\
\text { 乐游原上清秋节, } \\
\text { 咸阳古道音尘绝。 } \\
\text { 音尘绝, } \\
\text { 西风残照, } \\
\text { 汉家陵阙。 }\end{array}$ & $\begin{array}{l}\text { The flute sounded like it was sobbing sadly. } \\
\text { When Qi n E awoke from her dream, } \\
\text { she saw the bright moon hanging upstairs. } \\
\text { The bright moon is on the Qin Tower. } \\
\text { The willow by the bridge turns green every year. } \\
\text { The moon and willow complete the scene of their } \\
\text { parting sorrow on the Ba bridge. } \\
\text { She gazed towards the old distant and desolate autumn } \\
\text { season at the Leyou Garden. } \\
\text { There hadn't been any news about him on the old road } \\
\text { leading to Xianyang city for a long time. } \\
\text { There was no news about him anymore. } \\
\text { The westerly wind blew the light of the setting sun. } \\
\text { Before me, there are only the tombs and palace urns left } \\
\text { by the Han Dynasty. }\end{array}$ & $\begin{array}{l}\text { xiāo shēng yān, } \\
\text { qín é mèng duàn qín } \\
\text { lóu yuè. } \\
\text { qín lóu yuè, } \\
\text { nián nián liǔ sè, } \\
\text { bà líng shāng bié. } \\
\text { lè yóu yuán shàng } \\
\text { qīng qiū jiê,xián yáng } \\
\text { gǔ dào yīn chén jué. } \\
\text { yīn chén jué, } \\
\text { xī fêng cán zhào, } \\
\text { hàn jiā líng què. }\end{array}$ \\
\hline
\end{tabular}

${ }^{89}$ The Ba Bridge was the site where Qin E and her lover parted ways. 
Composer: Ying Shangneng (应尚能, 1902-1973)

Title: Wo Nong Ci (我侬泀, 1940)

Title translation: The poem of You and I

Poet: Guan Daosheng (管道升, 1262-1339)

\begin{tabular}{|c|c|c|}
\hline 我侬词 & The poem of You and I & Wǒ Nóng Cí \\
\hline $\begin{array}{l}\text { 你侬我侬, 式鞄情多, } \\
\text { 情多处, 热如火。 } \\
\text { 把一块泥, 捻一个你, 塑一个 } \\
\text { 我。 } \\
\text { 将咱两个, 一齐打破, 用水调 } \\
\text { 和。 } \\
\text { 再捻一个你, 再塑一个我。 } \\
\text { 我泥中有你, 你泥中有我。 } \\
\text { 与你生同一个衾, 死同一个 } \\
\text { 槨。 }\end{array}$ & $\begin{array}{l}\text { You are I. I am You. } \\
\text { Our love is deep. } \\
\text { It is like flame. } \\
\text { Let's take a piece of clay and make half of it into } \\
\text { you and the other half into me. } \\
\text { Then let's crush both of them together and stir } \\
\text { them into water. (now it becomes clay again.) } \\
\text { Then let's use this piece of clay again. We will } \\
\text { make half of into you and the other half into me } \\
\text { again. } \\
\text { Now my piece of clay has part of you and your } \\
\text { piece of clay has part of me. } \\
\text { I will be sharing my life with you. } \\
\text { And I will be buried together with you. }\end{array}$ & 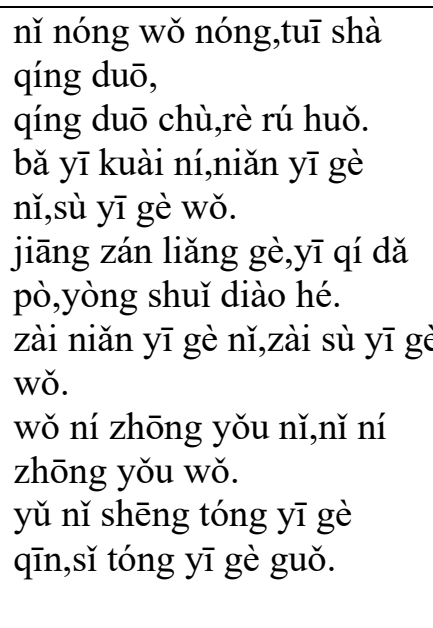 \\
\hline
\end{tabular}


Composer: Ying Shangneng (应尚能, 1902-1973)

Title: Yu Fu (渔夫, 1942)

Title translation: Old Fisherman

Poet: Sushi (苏轱, 1037-1101)

\begin{tabular}{|c|c|c|}
\hline 渔夫 & Old Fisherman & Yú Fū \\
\hline $\begin{array}{l}\text { 渔父饮, 谁家去? } \\
\text { 鱼蟹一时分付。 } \\
\text { 酒无多少醉为期, } \\
\text { 彼此不论钱数。 } \\
\text { 渔父醉, 蓑衣舞, } \\
\text { 醉里却寻归路。 } \\
\text { 轻舟短棹任斜横, } \\
\text { 醒后不知何处。 } \\
\text { 渔父醒, 春江午, } \\
\text { 梦断落花飞絮。 } \\
\text { 酒醒还醉醉还醒, } \\
\text { 一笑人间今古。 } \\
\text { 渔父笑, 轻鸥举, } \\
\text { 漠漠一江风雨。 } \\
\text { 江边骑马是官人, } \\
\text { 借我孤舟南渡。 }\end{array}$ & $\begin{array}{l}\text { The fisherman wants to have a drink. } \\
\text { Which restaurant should I go to? } \\
\text { Fish and crab were handed over to the restaurant to trade for a drink. } \\
\text { I will drink as much as I want and will not stop until I am drunk. } \\
\text { There is no need to compare the value of my fish and crab with the } \\
\text { restaurant's wine. } \\
\text { The fisherman was drunk. He walked in a raincoat and stumbled like } \\
\text { he was dancing. } \\
\text { The drunk fisherman wanted to find his way home. } \\
\text { The sculling boat is left unattended, letting it drift away freely. } \\
\text { After waking up, the fisherman didn't know where he was. } \\
\text { After the fisherman woke up, it was noon on the Chunjiang River. } \\
\text { I woke up and saw bursts of flowers flying. } \\
\text { When you wake up, you will get drunk again. } \\
\text { When you are drunk, you will wake up again. } \\
\text { I laughed at all the world's achievements and fame. } \\
\text { The fisherman laughed and chanted at the sky. } \\
\text { The fluttering river gulls were flying, } \\
\text { and the wind was blowing in the rain on the wide Yangtze River. } \\
\text { There is a junior officer on his horse by the river. } \\
\text { Surprisingly, he is now asking to borrow my boat to cross the } \\
\text { Yangtze River to the south. }\end{array}$ & $\begin{array}{l}\text { yú fù yǐn,shuí jiā qù ? } \\
\text { yú xiè ȳi shí fèn fù . } \\
\text { jiǔ wú duō shăo zuì } \\
\text { wéi qī, } \\
\text { bǐ cí bú lùn qián shù. } \\
\text { yú fù zuì,suō yī wǔ, } \\
\text { zuì lǐ què xún guī lù . } \\
\text { qīng zhōu duăn zhào } \\
\text { rèn xié héng, } \\
\text { xǐng hòu bú zhī hé } \\
\text { chù. } \\
\text { yú fù xǐng,chūn jiāng } \\
\text { wǔ, } \\
\text { mèng duàn luò huā fêi } \\
\text { xù. } \\
\text { jiǔ xǐng hái zuì zuì hái } \\
\text { xǐng, } \\
\text { yī xiào rén jiān jīn gŭ. } \\
\text { yú fù xiào,qīng ōu jǔ, } \\
\text { mò mò yī jiāng fēng } \\
\text { yǔ . } \\
\text { jiāng biān qí mă shì } \\
\text { guān rén, } \\
\text { jiè wǒ gū zhōu nán dù. }\end{array}$ \\
\hline
\end{tabular}


Composer: Zhang Shu (张曙, 1908-1938)

Poet: Tian Han (田汉, 1898-1968)

Title: Ri Luo Xi Shan (日落西山, 1935)

Title translation: Sunset of the West Mountain

\begin{tabular}{|c|c|c|}
\hline 日落西山 & Sunset of the West Mountain & Rì Luò Xī Shān \\
\hline $\begin{array}{l}\text { 日落西山满天霞, } \\
\text { 对面山上来了一个俏冤家。 } \\
\text { 眉儿弯弯眼儿大, } \\
\text { 头上插了一朵小茶花。 } \\
\text { 哪一个山上没有树? } \\
\text { 哪一个田里没有瓜? } \\
\text { 哪一个男子心里没有意? } \\
\text { 要打鬼子可就顾不了她! }\end{array}$ & $\begin{array}{l}\text { The Sun was setting over the west mountain. } \\
\text { The sky was full of sunset clouds. } \\
\text { A beautiful friend came upon the opposite } \\
\text { hill. } \\
\text { Her curved eyebrows and her big eyes were } \\
\text { beautiful. } \\
\text { She put a little camellia in her hair. } \\
\text { Which mountain has no trees? } \\
\text { Which field has no melons? } \\
\text { Which man has never pursued love? } \\
\text { I can't go pursue her now if I'm going to fight } \\
\text { the war. }\end{array}$ & $\begin{array}{l}\text { rì luò xī shān măn tiān xiá, } \\
\text { duì miàn shān shàng lái le yī gè qiào yuān } \\
\text { jiā. } \\
\text { méi ér wān wān yăn ér dà, } \\
\text { tóu shàng chā le yī duǒ xiăo chá huā. } \\
\text { nă yī gè shān shàng méi yǒu shù? } \\
\text { nă yī gè tián lǐ méi yǒu guā? } \\
\text { nǎ yī gè nán zǐ xīn lǐ méi yǒu yì? } \\
\text { yào dă guǐ zǐ kě jiù gù bú le tā! }\end{array}$ \\
\hline
\end{tabular}




\section{Appendix IV: Publisher Information}

Most of the Chinese art songs utilized in this study were selected from music scores published in China. These scores were primarily published by People's Music Publishing House and Shanghai Educational Publishing House. Shanghai Music Publishing House and Culture, and Art Publishing House have also published some of these Chinese art songs for vocal competition and certification exams in their various song books. The publisher's information is listed below:

\section{People's Music}

People's Music Publishing House

Ducheng Chaoyangmen Inner St., Jia 55

[东城区朝阳门内大街甲 55 号]

Beijing, China 100010

http://rymusic.com.cn

\section{SEPH}

Shanghai Educational Publishing House

123 Yongfu Rd.

[永福路 123 号]

Shanghai, China 200031

http://www.seph.com.cn

\section{SMPH}

Shanghai Music Publishing House

Huangpu, 443 Dapu Rd., Rongke Building 15-17F,

[黄浦区打浦路 443 号荣科大厦 15 17F]

Shanghai, China 200023

http://www.smph.cn/

\section{CAAPH}

Culture and Are Publishing House

Dongcheng, 52 Dongsi 8th Alley

[东城区东四八条 52 号]

Beijing, China 100700

http://www.caaph.com 


\section{Appendix V: Composer Index in Alphabetic Order}

\begin{tabular}{|c|c|c|c|c|}
\hline Composer & Composer (in Chinese) & Composer (in Pinyin) & $\begin{array}{r}\text { Title } \\
\end{array}$ & Title (in Chinese) \\
\hline \multirow{5}{*}{ Chen Tianhe } & \multirow{5}{*}{ 陈田鹤, 1911-1955 } & \multirow{5}{*}{ Chén Tiánhè } & Cai Sang Qu & 采桑曲, 1930s \\
\hline & & & Chun Gui He Chu & 春归何处, 1931 \\
\hline & & & Jiang Cheng Zi & 江城子, 1944 \\
\hline & & & Qiu Tian de Meng & 秋天的梦, 1936 \\
\hline & & & Shan Zhong & 山中, 1934 \\
\hline Chen Xiaokong & 陈啸空, 1904-1953 & Chén Xiàokōng & Xiang Lei & 湘累, 1924 \\
\hline Fan Jisen & 范继森, 1917-1969 & Fàn Jìsēn & An Shui Ba, Yong Shi & 安眠吧, 勇士, 1943 \\
\hline He Luting & 贺绿汀, 1903-1999 & Hè Lǜtīng & Jialing Jiang Shang & 嘉陵江上, 1939 \\
\hline Huang Yongxi & 黄永熙, 1917-2003 & Huáng Yǒngxī & Huai Nian Qu & 怀念曲, 1940s \\
\hline Huang Youdi & 黄友棣, 1911-2010 & Huáng Yǒudì & Du Juan Hua & 杜鹃花, 1941 \\
\hline \multirow{8}{*}{ Huang $\mathrm{Zi}$} & \multirow{8}{*}{ 黄自, 1904-1953 } & \multirow{8}{*}{ Huáng Zì } & Chun Si Qu & 春思曲, 1932 \\
\hline & & & $\begin{array}{l}\text { Dian Jiang Chun, Fu Deng } \\
\text { Lou }\end{array}$ & 点绛唇・赋登楼, 1934 \\
\hline & & & Hua Fei Hua & 花非花, 1933 \\
\hline & & & Meigui San Yua & 玫瑰三愿, 1932 \\
\hline & & & $\begin{array}{l}\text { Nan Xiang Zi, Deng Jing } \\
\text { Kou Beigu Ting You Huai }\end{array}$ & $\begin{array}{l}\text { 南乡子・登京口北固亭 } \\
\text { 有怀, } 1934\end{array}$ \\
\hline & & & Si Xiang & 思乡, 1932 \\
\hline & & & Ta Xue Xun Mei & 踏雪寻梅, 1933 \\
\hline & & & Xi Feng de Hua & 西风的话, 1934 \\
\hline \multirow{2}{*}{ Jiang Dingxian } & \multirow{2}{*}{ 江定仙, 1912-2000 } & Jiāng Dìngxiān & Kang Ding Qing Ge & 康定情歌, 1940s \\
\hline & & & Sui Yue You You & 岁月悠悠, 1936 \\
\hline Jiang Wenye & 江文也, 1910-1983 & Jiāng Wényě & Shang Chun & 伤春, 1939 \\
\hline Jin Sha & 金砂, 1922-1996 & Jīn Shā & Mu Yang Gu Niang & 牧羊姑娘, 1941 \\
\hline Lao Zhicheng & 老志诚, 1910-2006 & Lǎo Zhìchéng & Leifeng Ta Ying & 雷锋塔影, 1932 \\
\hline
\end{tabular}




\begin{tabular}{|c|c|c|c|c|}
\hline Composer & Composer (in Chinese) & Composer (in Pin Yin) & Title & Title (in Chinese) \\
\hline Li Weining & 李惟宁, 1910-1985 & Lǐ Wéiníng & Ou Ran & 偶然, 1937 \\
\hline \multirow{3}{*}{ Lin Shengxi } & \multirow{3}{*}{ 林声翕, 1914-1991 } & \multirow{3}{*}{ Lín Shēngxī } & Bai Yun Gu Xiang & 白云故乡,1938 \\
\hline & & & $\begin{array}{l}\text { Shui Diao Ge Tou: Ming } \\
\text { Yue Ji Shi You }\end{array}$ & $\begin{array}{l}\text { 水调歌头 . 明月几时有, } \\
1942\end{array}$ \\
\hline & & & Wang Yun & 望云,1938 \\
\hline \multirow{4}{*}{ Liu Xue'an } & \multirow{4}{*}{ 刘雪庵, 1905-1985 } & \multirow{4}{*}{ Liú Xuě’ān } & Chang Cheng Yao & 长城谣, 1937 \\
\hline & & & Hong Dou Ci & 红豆词, 1943 \\
\hline & & & Piao Ling de Luo Hua & 飘零的落花, 1935 \\
\hline & & & Zhui Xun & 追寻, 1938 \\
\hline \multirow{2}{*}{ Lu Huabai } & \multirow{2}{*}{ 陆华柏, 1914-1994 } & \multirow{2}{*}{ Lù Huábăi } & Gu Xiang & 故乡,1937 \\
\hline & & & Yong Shi Gu & 勇士骨,1938 \\
\hline $\mathrm{Ma} \mathrm{Ke}$ & 马克, 1918-1976 & Mă Kè & Nan Ni Wan & 南泥湾, 1943 \\
\hline Ma Sicong & 马思聪, 1912-1987 & Mă Sīcōng & Hai Shang & 海上, 1943 \\
\hline \multirow{3}{*}{ Nie Er } & \multirow{3}{*}{ 聂耳, 1921-1935 } & \multirow{3}{*}{ Niè ěr } & Gao Bie Nan Yang & 告别南洋, 1934 \\
\hline & & & Mei Niang Qu & 梅娘曲, 1934 \\
\hline & & & Tie Ti Xia de Ge Nv & 铁蹄下的歌女, 1935 \\
\hline \multirow{2}{*}{ Qing Zhu } & \multirow{2}{*}{ 青主, 1893-1959 } & Qīng Zhǔ & Da Jiang Dong Qu & 大江东去, 1920 \\
\hline & & & Wo Zhu Changjiang Tou & 我住长江头, 1930 \\
\hline Ren Guang & 任光, 1990-1941 & Rèn Guāng & Yu Guangqu & 渔光曲, 1934 \\
\hline Sha Mei & 沙梅, 1909- & Shā Méi & Da Chai Ge & 打柴歌, 1930s \\
\hline \multirow{4}{*}{ Tan Xiaolin } & \multirow{4}{*}{ 谭小麟, 1912-1948 } & \multirow{4}{*}{ Tán Xiăolín } & Bie Li & 别离, 1946 \\
\hline & & & Peng Lang Ji & 彭浪矶, 1944 \\
\hline & & & Zheng Qi Ge & 正气歌, 1947 \\
\hline & & & Zi Jun Zhi Chu Yi & 自君之出矣, 1945 \\
\hline Wang Luobin & 王洛宾, 1913-1996 & Wáng Luòbīn & $\begin{array}{l}\text { Zai Na Yao Yuan de Di } \\
\text { Fang }\end{array}$ & 在那遥远的地方, 1939 \\
\hline Xia Zhiqiu & 夏之秋, 1912-1993 & Xià Zhīqiū & Si Xiang Qu & 思乡曲, 1939 \\
\hline
\end{tabular}




\begin{tabular}{|c|c|c|c|c|}
\hline Composer & $\begin{array}{l}\text { Composer (in } \\
\text { Chinese) }\end{array}$ & Composer (in Pin Yin) & Title & Title (in Chinese) \\
\hline \multirow{5}{*}{ Xian Xinghai } & \multirow{5}{*}{ 冼星海, 1905-1945 } & \multirow{5}{*}{ Xiăn Xīnghăi } & Huang He Song & 黄河颂, 1939 \\
\hline & & & Huang Heyuan & 黄河怨, 1939 \\
\hline & & & Huang Shuiyao & 黄水谣, 1939 \\
\hline & & & Ye Ban Ge Sheng & 夜半歌声, 1937 \\
\hline & & & Yi Qin'e: Xiao Shengyan & 忆秦娥·箫声咽, 1940 \\
\hline Xiao Youmei & 萧友梅, 1884-1940 & Xiāo Yǒuméi & Wen & 问, 1922 \\
\hline \multirow{3}{*}{$\begin{array}{l}\text { Ying } \\
\text { Shangneng }\end{array}$} & \multirow{3}{*}{ 应尚能, 1902-1973 } & \multirow{3}{*}{ Yīng Shàngnéng } & Diao Wusong & 吊吴淞, 1933 \\
\hline & & & Wo Nong Ci & 我侬词, 1940 \\
\hline & & & $\mathrm{Yu} \mathrm{Fu}$ & 渔夫, 1942 \\
\hline Zhang Hanhui & 张寒晖, 1902-1946 & Zhāng Hánhuī & Songhua Jiang Shang & 松花江上, 1936 \\
\hline Zhang Shu & 张曙, 1908-1938 & Zhāng Shǔ & Ri Luo Xi Shan & 日落西山, 1935 \\
\hline Zhang Xiaohu & 张肖虎, 1914-1997 & Zhāng Xiāohǔ , & $\begin{array}{l}\text { Sheng Sheng Man: Xun } \\
\text { Xun Mi Mi }\end{array}$ & 声声慢·寻寻受受, 1933 \\
\hline \multirow{6}{*}{ Zhao Yuanren } & \multirow{6}{*}{ 赵元任, 1892-1982 } & \multirow{6}{*}{ Zhào Yuánrèn } & $\begin{array}{l}\text { Jiao Wo Ru He Bu Xiang } \\
\text { Ta }\end{array}$ & 教我如何不想他, 1926 \\
\hline & & & Mai Bu Yao & 卖布谣, 1922 \\
\hline & & & Qiu Zhong & 秋钟, 1922 \\
\hline & & & Shang Shan & 上山, 1926 \\
\hline & & & Ting Yu & 听雨, 1927 \\
\hline & & & Ye Shi Wei Yun & 也是微云, 1926 \\
\hline Zheng Lvcheng & 郑律成, 1914-1976 & Zhèng Lǜchéng & Yan Shui Yao & 延水谣, 1938 \\
\hline Zhou Shu'an & 周淑安, 1894-1974 & Zhōu Shū'ān & $\mathrm{Yu}$ & 雨, 1932 \\
\hline
\end{tabular}




\section{Appendix VI: Title Index in Alphabetic Order}

\begin{tabular}{|c|c|c|c|}
\hline Title (page numbers) $)^{90}$ & Title in Chinese & Title in Pinyin & Title's English Translation \\
\hline An Shui Ba, Yong Shi $(68,141)$ & 安眠吧, 勇士, 1943 & Ān Mián Bā, Yǒng Shì & Rest in Pease, Warriors \\
\hline Bai Yun Gu Xiang $(43,116)$ & 白云故乡,1938 & Bái Yún Gù Xiāng & White Cloud and Hometown \\
\hline Bie Li $(77,150)$ & 别离, 1946 & Bié Lí & Saying Goodbye \\
\hline Cai Sang Qu $(30,103)$ & 采桑曲, 1930s & Căi Sāng Qū & $\begin{array}{l}\text { The Song of Picking Mulberry } \\
\text { Leaves }\end{array}$ \\
\hline Chang Cheng Yao $(47,120)$ & 长城谣, 1937 & Cháng Chéng Yáo & The Ballad of the Great Wall \\
\hline Chun Gui He Chu $(27,100)$ & 春归何处, 1931 & Chūn Guī Hé Chǔ & Where does Spring Belong \\
\hline Chun Si Qu $(34,107)$ & 春思曲, 1932 & Chūn Sī Qū & Song of Spring Thoughts \\
\hline Da Chai Ge $(55,128)$ & 打柴歌, 1930s & Dă Chái Gē & Chopping Wood Song \\
\hline Da Jiang Dong Qu $(17,90)$ & 大江东去, 1920 & Dà Jiāng Dōng Qù & The River Flowing to the East \\
\hline $\begin{array}{l}\text { Dian Jiang Chun, Fu Deng Lou } \\
(39,112)\end{array}$ & 点绛唇・赋登楼, 1934 & $\begin{array}{l}\text { Diăn Jiàng Chún • Fù Dēng } \\
\text { Lóu }\end{array}$ & $\begin{array}{l}\text { Dian Jiang Chun, Ode to Ascending } \\
\text { the Tower }\end{array}$ \\
\hline Diao Wusong $(62,135)$ & 吊吴淞, 1933 & Diào Wú Sōng & $\begin{array}{l}\text { Commemorate of the Dead Soldiers } \\
\text { at Wu Song }\end{array}$ \\
\hline Du Juan Hua $(70,143)$ & 杜鹃花, 1941 & Dù Juān Huā & The Rhododendron \\
\hline Gao Bie Nan Yang $(51,124)$ & 告别南洋, 1934 & Gào Bié Nán Yáng & Farewell to the South Asia \\
\hline Gu Xiang $(49,122)$ & 故乡,1937 & Gù Xiāng & Hometown \\
\hline Hai Shang $(76,149)$ & 海上, 1943 & Hăi Shàng & On the Sea \\
\hline Hong Dou Ci $(74,147)$ & 红豆词, 1943 & Hóng Dòu Cí & The Poem of the Red Beans \\
\hline Hua Fei Hua $(35,108)$ & 花非花, 1933 & Huā Fēi Huā & Flowers are not Flowers \\
\hline Huai Nian Qu $(69,142)$ & 怀念曲, 1940s & Huái Niàn Qū & The Yearning Song \\
\hline Huang He Song $(59,132)$ & 黄河颂, 1939 & Huáng Hé Sòng & Ode to the Yellow River \\
\hline Huang Heyuan $(61,134)$ & 黄河怨, 1939 & Huáng Hé Yuàn & Yellow River Resentment \\
\hline
\end{tabular}

90 Two page numbers are listed here. The first page number referred to the page of annotated list of the song. The second page number refers to the page of the lyric and translation of the song. 


\begin{tabular}{|c|c|c|c|}
\hline Title(page numbers) & Title in Chinese & Title in Pinyin & Title's English Translation \\
\hline Huang Shuiyao $(60,133)$ & 黄水谣, 1939 & Huáng Shuǐ Yáo & Yellow River Ballad \\
\hline Jialing Jiang Shang $(31,104)$ & 嘉陵江上, 1939 & Jiālíng Jiāng Shàng & On the Jialing River \\
\hline Jiang Cheng Zi $(67,140)$ & 江城子, 1944 & Jiāng Chéng Zĩ & Jiang Cheng Zi \\
\hline $\begin{array}{l}\text { Jiao Wo Ru He Bu Xiang Ta } \\
(22,96)\end{array}$ & 教我如何不想他, 1926 & Jiào Wǒ Rú Hé Bù Xiăng Tā & $\begin{array}{l}\text { How Can I Keep from Thinking of } \\
\text { You? }\end{array}$ \\
\hline Kang Ding Qing Ge $(72,145)$ & 康定情歌, 1940s & Kāng Dìng Qíng Gē & Kongding Love Song \\
\hline Leifeng Ta Ying $(42,115)$ & 雷锋塔影, 1932 & Léifēng Tă Yĩng & The Shadow of Leifeng Tower \\
\hline Mai Bu Yao $(25,98)$ & 卖布谣, 1922 & Mài Bù Yáo & Fabric Selling Ballad \\
\hline Meiniang Qu $(52,125)$ & 梅娘曲, 1934 & Méiniáng Qū & Song of Meiniang \\
\hline Meigui San Yua $(32,105)$ & 玫瑰三愿, 1932 & Méiguī Sān Yuàn & The Three Wishes of the Rose \\
\hline Mu Yang Gu Niang $(71,144)$ & 牧羊姑娘, 1941 & Mù Yáng Gū Niáng & The Shepherd Girl \\
\hline Nan Ni Wan $(75,148)$ & 南泥湾, 1943 & Nán Ní Wān & The Nanni Bay \\
\hline $\begin{array}{l}\text { Nan Xiang Zi, Deng Jing Kou } \\
\text { Beigu Ting You }(38,111)\end{array}$ & $\begin{array}{l}\text { 南乡子・登京口北固 } \\
\text { 亭有怀, } 1934\end{array}$ & $\begin{array}{l}\text { Nán Xiāng Zǐ • Dēng Jīng } \\
\text { Kǒu Běigù Tíng Yǒu Huái }\end{array}$ & $\begin{array}{l}\text { Nan Xiang Zi, Having Thoughts } \\
\text { while Boarding Beigu Pavilion at } \\
\text { the City of Jingkou }\end{array}$ \\
\hline Ou Ran $(44,118)$ & 偶然, 1937 & Ǒu Rán & By Chance \\
\hline Peng Lang Ji $(80,153)$ & 彭浪矶, 1944 & Péng Làng $\mathrm{J} \overline{1}$ & The Penglang Rock \\
\hline Piao Ling de Luo Hua $(46,119)$ & 飘零的落花, 1935 & Piāo Líng De Luò Huā & The Falling Flowers \\
\hline Qiu Tian de Meng $(29,102)$ & 秋天的梦, 1936 & Qiū Tiān De mèng & Autumn's Dream \\
\hline Qiu Zhong $(24,97)$ & 秋钟, 1922 & Qiū Zhōng & The Autumn Bell \\
\hline Ri Luo Xi Shan $(84,157)$ & 日落西山, 1935 & Rì Luò Xī Shān & Sunset of the West Mountain \\
\hline Shan Zhong $(28,101)$ & 山中, 1934 & Shān Zhōng & In the Mountain \\
\hline Shang Chun $(41,114)$ & 伤春, 1939 & Shāng Chūn & Sad Spring \\
\hline Shang Shan $(20,93)$ & 上山, 1926 & Shàng Shān & Climbing the Mountain \\
\hline $\begin{array}{l}\text { Sheng Sheng Man: Xun Xun Mi } \\
\text { Mi }(64,137)\end{array}$ & $\begin{array}{l}\text { 声声慢・寻寻受受, } \\
1933\end{array}$ & $\begin{array}{l}\text { Shēng Shēng Màn • Xún } \\
\text { Xún Mì Mì }\end{array}$ & Sheng Sheng Man: The Searching \\
\hline
\end{tabular}




\begin{tabular}{|c|c|c|c|}
\hline Title (page numbers) & Title (in Chinese) & Title in Pinyin & Title's English Translation \\
\hline $\begin{array}{l}\text { Shui Diao Ge Tou: Ming Yue Ji } \\
\text { Shi You }(73,146)\end{array}$ & $\begin{array}{l}\text { 水调歌头・明月几时 } \\
\text { 有, } 1942\end{array}$ & $\begin{array}{l}\text { Shuǐ Diào Gē Tóu • Míng } \\
\text { Yuè Jĩ Shí Yǒu }\end{array}$ & $\begin{array}{l}\text { The Prelude of the Water Tune: } \\
\text { How Long Until the Full Moon } \\
\text { Appears? }\end{array}$ \\
\hline Si Xiang $(33,106)$ & 思乡, 1932 & Sī Xiāng & Homesick \\
\hline Si Xiang Qu $(57,130)$ & 思乡曲, 1939 & Sī Xiāng Qǔ & The Song of Homesickness \\
\hline Songhua Jiang Shang $(63,136)$ & 松花江上, 1936 & Sōnghuā Jiāng Shàng & On the Songhua River \\
\hline Sui Yue You You $(40,113)$ & 岁月悠悠, 1936 & Suì Yuè Yōu Yōu & Years Long ago \\
\hline Ta Xue Xun Mei $(36,109)$ & 踏雪寻梅, 1933 & Tà Xuě Xún Méi & Stepping in the Snow to Find Plums \\
\hline Tie Ti Xia de Ge Nv $(53,126)$ & 铁蹄下的歌女, 1935 & Tiě Tí Xià Dí Gē Nŭ & $\begin{array}{l}\text { The Singing Women under the Iron } \\
\text { Hoof }\end{array}$ \\
\hline Ting $\mathrm{Yu}(21,95)$ & 听雨, 1927 & Tīng Yǔ & Listening to the Rain \\
\hline Wang Yun $(45,117)$ & 望云,1938 & Wàng Yún & Watch the Clouds \\
\hline Wen $(19,92)$ & 问, 1922 & Wèn & Question \\
\hline Wo Nong Ci $(82,155)$ & 我侬词, 1940 & Wǒ Nóng Cí & The poem of You and I \\
\hline Wo Zhu Changjiang Tou $(18,91)$ & 我住长江头, 1930 & Wǒ Zhù Chángjiāng Tóu & $\begin{array}{l}\text { I Live Near the Source of the } \\
\text { Changjiang River }\end{array}$ \\
\hline Xi Feng de Hua $(37,110)$ & 西风的话, 1934 & Xī Fēng de Huà & The Words of the West Wind \\
\hline Xiang Lei $(16,88)$ & 湘累, 1924 & Xiāng Léi & Xiang's Weary \\
\hline Yan Shui Yao $(65,138)$ & 延水谣, 1938 & Yán Shuǐ Yáo & The Ballade of Yan River \\
\hline Ye Ban Ge Sheng $(58,131)$ & 夜半歌声, 1937 & Yè Bàn Gē Shēng & \begin{tabular}{|l} 
Singing at Midnight \\
\end{tabular} \\
\hline Ye Shi Wei Yun $(26,99)$ & 也是微云, 1926 & Yě Shì Wēi Yún & Also, Are the Smallest Clouds \\
\hline Yi Qin'e: Xiao Shengyan $(81,154)$ & 忆秦娥・箫声咽, 1940 & Yì Qín É • Xiāo Shēng Yān & Memories of Qin'e: Weeping Flute \\
\hline Yong Shi Gu $(50,123)$ & 勇士骨,1938 & Yǒng Shì Gŭ & The Warriors' Bones \\
\hline $\mathrm{Yu}(66,139)$ & 雨, 1932 & Yǔ & Rain \\
\hline
\end{tabular}




\begin{tabular}{|l|l|l|l|}
\hline \multicolumn{1}{|c|}{ Title (page numbers) } & \multicolumn{1}{|c|}{ Title (in Chinese) } & \multicolumn{1}{c|}{ Title in Pinyin } & \multicolumn{1}{c|}{ Title’s English Translation } \\
\hline Yu Fu (83,156) & 渔夫, 1942 & Yú Fū & Old Fisherman \\
\hline Yu Guangqu (54,127) & 渔光曲, 1934 & Yú Guāng Qū & Fisherman's Song \\
\hline $\begin{array}{l}\text { Zai Na Yao Yuan de Di Fang } \\
(56,129)\end{array}$ & Zài Nà Yáo Yuăn de Dì Fāng & At That Distant Place \\
\hline Zheng Qi Ge (78,151) & 正气的地方, 1939, 1947 & Zhèng Qì Gē & The Song of Righteousness \\
\hline Zhui Xun (48,121) & 追寻, 1938 & Zhuī Xún & The Pursuit \\
\hline Zi Jun Zhi Chu Yi (79,152) & 自君之出矣, 1945 & Zì Jūn Zhī Chū Y̌̃ & Since the Day of Your Departure \\
\hline
\end{tabular}

